Elisa Maria Parahyba Campos

\title{
A PSICO-OnCOLOGIA: UMA NOVA VISÃo DO CÂNCER - UMA TRAJETÓRIA
}




\section{Elisa Maria Parahyba Campos}

\section{A PSICO-OnCOLOGIA: UMA NOVA VISÃo DO CÂNCER - UMA TRAJETÓRIA}


AUTORIZO A REPRODUÇÃO E DIVULGAÇÃO TOTAL OU PARCIAL DESTE TRABALHO, POR QUALQUER MEIO CONVENCIONAL OU ELETRÔNICO, PARA FINS DE ESTUDO E PESQUISA, DESDE QUE CITADA A FONTE.

\author{
Catalogação na Publicação \\ BIBLIOTECA DANTE MOREIRA LEITE \\ Instituto de PSicologia dA UnIVERSIDAdE DE SÃO PAULO
}

CAMPOS, Elisa Maria Parahyba

A PSico-Oncologia: Uma nova VisÃo Do CÂNCER - Uma TRAJetÓRIA/Elisa Maria PARAHYBa CAMPOS - 2010.

$155 \mathrm{~F}$.

Tese (LivRe-Docência - Departamento de Psicologia Clínica

- Instituto de Psicologia da Universidade de SÃo PAulo)

1.PSICO-ONCOLOGIA 2.NEOPLASIAS 3.PSICOTERAPIA DE GRUPO 4. PACIENTES TERMINAIS 5.PESQUISA QUALITATIVA 6.TÍTULO

$\mathrm{RC} 261$ 


\title{
FOLHA DE APROVAÇÃO
}

\author{
Elisa Maria Parahyba Campos
}

A Psico-Oncologia: Uma Nova Visão Do CÂNCER - Uma TrajetóRia

TESE APRESENTADA AO INSTITUTO DE PSICOLOGIA DA UNIVERSIDADE DE SÃo PAULO PARA OBTENÇÃO DO TÍTULO DE LIVRE-DOCENTE

APROVADO EM 1 1

BANCA EXAMINADORA

PROF. DR.

INSTITUIÇÃO ASSINATURA

PROF. DR.

INSTITUIÇÃO ASSINATURA

Prof. DR.

INSTITUIÇÃO ASSINATURA

PROF. DR. INSTITUIÇÃO ASSINATURA

PROF. DR. INSTITUIÇÃO ASSINATURA 
Conta-se que um dia a terra foi inundada por um enorme dilúvio, e que todos os sentimentos viram-se ilhados pelas águas que subiam perigosamente.

o amor decidiu ajudar aos colegas, e foi dando um jeito de colocar a salvo cada sentimento. Ao final de algum tempo, viu-se rodeado pelas águas, sozinho, em situação de grande perigo.

Fez sinais desesperados para os sentimentos que, a salvo, olfavam a cena. A alegria, a tristeza, o medo, enfim, todos tinham uma desculpa para não dar atenção ao amor, dizendo que não entendiam o que ele estava querendo dizer.

Finalmente, um velho passou em um barco e parou, transportando o amor para a margem, são e salvo. Ao virar-se para agradecer, o amor não viu mais o velho nem o barco.

Consultando o oráculo, o amor perguntou que sentimento era aquele que havia percebido seu desespero, salvando-o. Foi lhe dito que aquele velho não era um sentimento, mas que era o Tempo, porque só o tempo é capaz de entender os sinais do Amor...

CHRONOS é o Deus do tempo na Mitologia Grega.

Escolhemos o nome deste deus, para o laboratório de estudos e assistência a pacientes portadores de câncer porque achamos que algumas vezes é difícil entender as demandas angustiadas dos pacientes portadores de câncer e seus familiares. Precisamos de um tempo que muitas vezes o paciente já não tem, mas sempre conseguimos prestar um tipo de auxilio que não é em vão.

Dedico este trabalho a todos aqueles que responderam a um sinal de amor e investiram muito de seu tempo colaborando comigo em minhas atividades com os pacientes portadores de cancer nossos verdadeiros mestres.

A todos os colaboradores que um dia passaram pelo Chronos,

Minha Gratidão. 
Agradeço à Profa. Dra. Maria Margarida de Carvalho - Magui - por ter me apresentado à Psico-Oncologia, pelas inúmeras portas que abriu para mim, e pela leitura cuidadosa dos originais acrescentando observações que muito enriqueceram este trabalho.

A Profa. Dra. Eva Maria Migliavacca pelo estímulo e confiança em meu trabalho, fatores decisivos em minha decisão para sua realização.

Minha gratidão imensa a Myrna Pia Favilli, minha analista, que me ajudou de maneira especial, mostrando-me caminhos que sem suas intervenções eu não enxergaria.

À Profa. Lílian Frazão, Maria Regina Junqueira, Maria Laura Cury Silvestre, Profa. Dra. Maria da Glória Gimenes, por suas sugestões e leituras dos capítulos, e mais do que tudo por seu carinho.

A Clarice Guimarães e Ivete Yavo, minhas colaboradoras diretas junto ao Chronos, que dirigiram o serviço em minhas prolongadas ausências ao longo do ultimo ano. Sem elas, nossa atuação tanto no Laboratório quanto no Hospital Universitário não teria a eficiência que tem tido.

A Sonia Maria Caetano de Souza, por seu trabalho primoroso na organização dos documentos, na digitação e formatação final.

A Daniela Tsubota, que sempre juntou eficiência e alegria durante nossa estreita convivência neste ultimo ano.

A Cicera e Cláudia, secretarias do Departamento de Psicologia Clínica, por sua ajuda eficiente e prática, na hora da solução dos problemas administrativos, que me socorreram infinitas vezes sempre atenciosas e delicadas.

A minha sempre amiga Eliana Nogueira do Valle pela ajuda nos resumos em inglês. 
A mês chers amis Violette et Luic pour le résumé en français. Un bec.

À minha família, que nunca reclamou por minhas ausências nas alegres reuniões que promovem, e souberam compreender minhas necessidades.

À minha mãe, que apesar de seus 101 anos, telefonou todas as noites, para saber se já terminara, sempre desejando muita sorte. O telefonema terminava sempre com a frase "Que o Espírito Santo ilumine você".

Ao meu pai (in-memorian) que sempre incentivou meu trabalho.

Ao Dr. Avelino Luiz Rodrigues, meu marido e companheiro de muitas aventuras intelectuais e outras. Por suas colaborações discussões sobre Psicologia e Medicina, e muitas outras coisas. Sua paciência e amor iluminam minha vida.

Por ultimo, meu agradecimento àqueles que realmente me ensinaram muito sobre Psico-Oncologia, meus pacientes e seus familiares. Os que partiram, eu guardo dentro de mim, em um jardim muito florido para o qual fujo nos momentos mais difíceis, e do qual saio sempre renovada. 


\section{RESUMO}

Campos, M.E.P. A Psico-Oncologia: Uma nova Visão Do CÂncer - Uma Trajetória. 2010. 155 F. TESE de LIVRE-DOCÊNCIA. INSTITUTO DE PSICOLOGIA

O objetivo deste trabalho é difundir na academia, os conceitos que norteiam a Psico-Oncologia como uma nova área de conhecimento no atendimento ao paciente portador de câncer, seus familiares, equipes de saúde e à própria comunidade.

A partir de um relato histórico, pretende-se discutir o estado atual e as perspectivas desta interface entre a medicina e a psicologia, suas possibilidades em termos de uma ampliação do campo de atuação do psicólogo, além de um capítulo dedicado a uma reflexão sobre a metodologia possível, levando em conta a crise paradigmática que atingiu a contemporaneidade.

O surgimento da Psico-Oncologia é influenciado por diversos fatores relacionados ao desenvolvimento das ciências, mas não deixa de ser uma necessidade que responde a uma demanda dos últimos anos, quando o câncer não para de atingir cada vez mais pessoas, levando as pesquisas a descobertas intrigantes, mas que muitas vezes não explicam o surgimento e a evolução da doença.

A Psico-Oncologia nasce enfatizando os fatores psicossociais, biológicos e psicológicos no atendimento ao portador de câncer, e busca também uma compreensão maior dos processos de adoecimento e desenvolvimento da moléstia, e por último os problemas de adaptação à doença, bem como as implicações na vida familiar, social e profissional dos portadores de câncer.

A justificativa para isso é a necessidade de um informe sistematizado, com reflexões críticas necessárias, uma vez que ainda é escassa a informação sobre a área. Ao conviver com os benefícios que um atendimento fundado em conhecimentos da Psico-Oncologia promovem, tanto no paciente quanto em seus familiares e equipes de saúde, surgiu a necessidade de produzir algum conhecimento sobre tal vivência.

Relatando uma análise feita da produção de conhecimento ao longo dos primeiros dez anos de existência da área, pode-se delinear a tendência das pesquisas que serão desenvolvidas em futuro próximo desde que não se negligencie um entrosamento maior entre o exercício da clínica, a pesquisa e as políticas de saúde.

Palavras chave: Psico-Oncologia, neoplasias, psicoterapia de grupo, pacientes terminais, pesquisa qualitativa. 
CAmpos, M.E.P. Psycho-OnCology A new Vision of CANCER - A TRAJeCtory. 2010. TeSe de LIVRE-DOCÊNCIA. INSTITUTO DE PSICOLOGIA. 155 F.

This work aims at divulging, in the academic setting, the main concepts of Psycho-Oncology as a new area of knowledge, involving the attendance of cancer patients, their families and health teams as well as the community itself. Beginning with a historical account, a discussion will follow on the present situation, as well as the perspectives of this interface between Medicine and Psychology, emphasizing the possibilities that might expand the psychologist's field of work, while making some reflections towards a viable methodology, in face of the paradigmatic crisis that pervades the contemporary world.

Psycho-Oncology's creation was influenced by many different factors related to scientific development, also constituting an answer for a contemporary demand in face of an unprecedented number of new cases. This situation has conducted research to important discoveries, notwithstanding in many cases not being able to explain the causes nor the evolution of the disease.

Psycho-Oncology's creation was influenced by many different factors related to scientific development, also constituting an answer for a contemporary demand in face of an unprecedented number of new cases. This situation has conducted research to important discoveries, notwithstanding in many cases not being able to explain the causes nor the evolution of the disease.

Psycho-Oncology's creation was influenced by many different factors related to scientific development, also constituting an answer for a contemporary demand in face of an unprecedented number of new cases. This situation has conducted research to important discoveries, notwithstanding in many cases not being able to explain the causes nor the evolution of the disease.

The reasons justifying this work involve the need for a systematized account accompanied of some necessary critical reflections, since information on the area is still scarce. The need arose to produce some specific knowledge, after witnessing the benefits of a Psycho-Oncology therapy- based on the patients, their families, as well as on the health teams.

From the analysis of a body of knowledge in the area, created in the first ten years of existence, it is possible to infer a trend in new researches to be developed in the near future, provided that a greater interaction is not neglected among clinical experience, research and health politics.

Key-words: Psycho-Oncology, neoplasy, group psychotherapy, qualitative research, terminal patients. 


\section{RÉSUMÉ}

CAMPOS, M.E.P. LA PSYCHO-ONCOLOGIE - UNE NOUVELLE VISION SUR CANCER - UNE TRAJETOIRE. 2010. TESE DE LIVRE-DocênCIA. INSTITUTO DE PSiCologia. $155 \mathrm{~F}$.

L'objet de cette étude est de faire connaitre à l'académie, lês concepts qui orientent la psycho-oncologie em tant que nouvelle aire de connaissance sur lês soins du patient porteur de câncer, les famille, equipes de santé et sur la propre communauté. A partir d'um rapport historique, l'intention est de discuter l'état actuel e les perspectives de cet interface entre médecin et psycologie, sés possibilites em ce qui concerne um développement du secteur d'activité du psycologue, et em plus d'um chapitre concernant une reflexion sur la métodologie possible, considérant la crise equivalente qui atteint Id'dactualité. La apparition de la psycho-oncologie est influencée par divers facteurs se rapportant au développement dês sciences,mais néanmoins reste néacessaire face á une sollicitation de cer dernières années, devant la câncer quin e cesse d'daffliger, chaque fois davantage de gens, mis qui três souvent n'explique pas lápparition de la maladie. La psycho-oncologie nait en faisant ressortir lês facteurs psycho-sociaux, biologiques et psycologiques au cours du traitement du porteur de câncer et recherche également une compréhension plus grande du processus d'atteinte et de développement de la maladie et enfin, les problemes d'dadaptation face à cette maladie.

Paroles clès: psycho-oncologie, neoplasie, psycothérapie en group, recherche qualitatiave, patients en phase terminale. 


\section{SUMÁRIO}

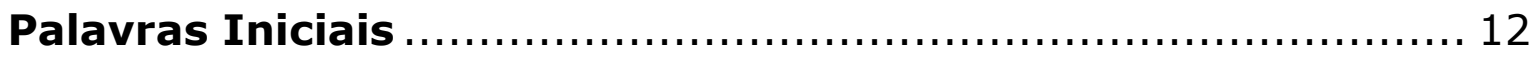

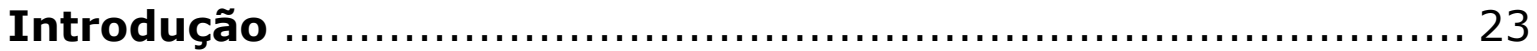

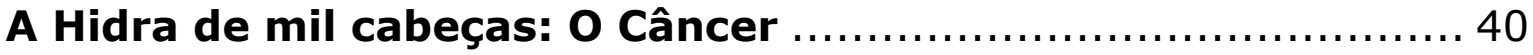

Aspectos Gerais ....................................................... 40

Histórico e características do câncer .................................. 43

Diagnóstico do câncer ................................................ 46

Tratamentos convencionais contra o câncer ........................... 48

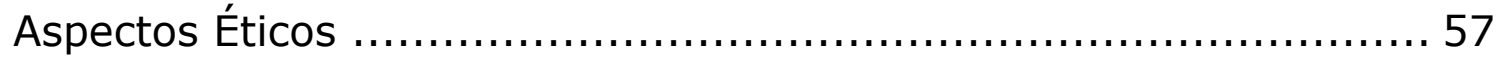

Psico-Oncologia: histórico ........................................... 60

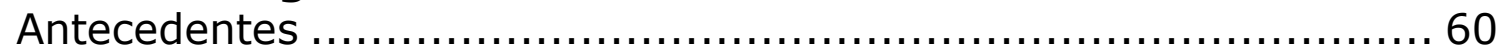

A Psico-Oncologia no Brasil ............................................ 71

Possibilidades de Intervenção em Psico-Oncologia ................ 77

Aspectos Gerais ........................................................ 77

Ajudando a Partir - A intervenção mais difícil .......................... 98

A Oficialização da Psico-Oncologia no Brasil....................... 104

Psico-Oncologia na Universidade de São Paulo..................... 109

Criação das Disciplinas .................................................... 109

O Laboratório Chronos - A História de um Serviço ................ 117

Os objetivos do laboratório: ....................................... 118

Os membros do Laboratório: ......................................... 119

Serviços prestados pelo Laboratório CHRONOS ........................ 119

a) Atuação junto ao Hospital Universitário da USP..................... 121

b) Atendimentos realizados pelo Laboratório Chronos no Hospital Universitário ......................................................... 124

A produção de conhecimento em psico-oncologia ................ 126

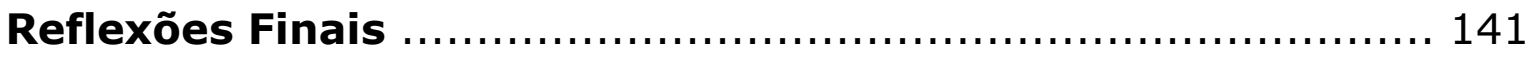

Referências Bibliográficas ........................................ 148

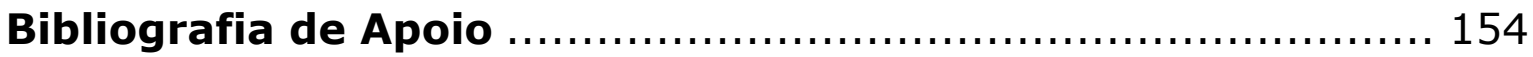




\section{Palavras Iniciais}

Escrevo levada pela necessidade de expor, a meus pares, a meus examinadores e a interlocutores em geral, tudo aquilo que foi surgindo como reflexão em torno da realização de uma Livre-Docência.

Por que fazer uma Livre-Docência? Ou nas palavras de Eco (1997) citado por Turato, 2003, p.123):

"Fazer uma tese significa aprender a pôr ordem nas próprias ideias e ordenar os fatos; é uma experiência de trabalho metódico, quer dizer, construir um 'objeto' que, a princípio, sirva também aos outros".

Existem diferentes razões para se fazer uma Livre-Docência, entre as quais se incluem o desejo de dar continuidade a uma carreira docente, e outras presas à obrigatoriedade institucional.

O tempo passou rápido, e deparei-me com a aposentadoria compulsória batendo à minha porta, sem aviso prévio, ou talvez eu não tenha desejado tomar ciência dos avisos que sempre existem.

A partir da proximidade de uma compulsória, parece mais estranha ainda a decisão pela Livre-Docência.

Após muito refletir, percebi que a etapa que se apresentava como um desafio era na verdade um desejo de fazer uma síntese de minha carreira docente, legando aos futuros eventuais consultores de meu trabalho, o conhecimento que amealhei nesses longos e felizes anos.

Durante o tempo que dediquei à docência e à pesquisa, meus objetivos foram sempre fornecer aos alunos condições para 0 desenvolvimento de um pensamento crítico em relação aos textos e às informações que recebiam.

Tanto nas disciplinas obrigatórias como nas optativas, sempre tentei mostrar que o exercício da clínica vai além das paredes de um consultório particular. Sempre insisti para que ampliassem sua visão em relação a seu futuro como profissionais de psicologia. 
No mínimo há quatro décadas a atuação do psicólogo já era solicitada em instituições de saúde para fazer parte de equipes multidisciplinares onde o seu papel era cada vez mais reconhecido.

De acordo com Sebastiani (2000), os psicólogos iniciaram sua atuação na saúde na década de 50 , portanto antes da lei que regulamentou a profissão de psicólogo no Brasil.

Consequência desta realidade foi minha insistência no sentido de criar disciplinas voltadas para a Psicologia da Saúde, Hospitalar e PsicoOncologia para os alunos do curso de Graduação em Psicologia.

$\mathrm{Na}$ verdade, a atuação do Psicólogo, há muito tempo, vem exigindo uma reflexão por parte das Faculdades de Psicologia. A redação da Lei n. 4.119, de 27-08-1963, cap. III, § 10, tem hoje quase meio século de existência, e não contempla aquilo que é solicitado ao profissional de psicologia a partir das últimas décadas.

Cada vez mais a demanda por profissionais que possam atuar em instituições promotoras de saúde exige uma formação que abrange um leque de disciplinas e práticas bem mais amplo do que as exigidas há 46 anos atrás quando iniciei minha graduação.

Ribeiro (1991), em trabalho onde discute a identidade do psicólogo, demonstra como a legislação proposta no momento da constituição da Psicologia como profissão não levava em conta algumas atividades inerentes às funções desse profissional.

Diz a Lei: 4119 "Constitui função do Psicólogo a utilização de métodos e técnicas psicológicas com os seguintes objetivos:

- diagnóstico psicológico

- orientação profissional

- orientação psicopedagógica

- solução de problemas de ajustamento". 
De acordo com as funções relatadas acima, o atendimento a pacientes em instituições promotoras de saúde não constava como função a ser exercida pelo psicólogo.

A Psicologia da Saúde só aparece como campo estruturado de um novo saber, uma nova práxis, por volta de 1970, nos Estados Unidos, com a criação pela APA - American Psychological Association - de um grupo de trabalho na área da saúde. Castro e Bornholdt relatam que 1979 é criada a Health Psychology, cujos objetivos eram "avançar no estudo da Psicologia como uma disciplina que compreenderia a saúde e a doença através da pesquisa", e ainda "encorajar a integração da informação biomédica com o conhecimento psicológico fomentando e difundindo a área".

De acordo com as autoras acima, a Europa, seguindo a tendência americana, cria a European Health Psychology Society - EHPS, com objetivos semelhantes, ou seja, promover a pesquisa teórica e empírica e suas aplicações para a Psicologia da Saúde européia.

Na América Latina, no final dos anos 60 ocorreu o primeiro encontro de profissionais da área da saúde em Cuba, reunindo cerca de 1.000 interessados, tornando-se um marco para o reconhecimento da área.

No Brasil, a formação do profissional de Psicologia da Saúde existe em nível de Pós-Graduação oferecido por poucas instituições, o que limita o crescimento da área, mas durante os últimos anos, os psicólogos independentemente de seu referencial teórico, têm sabido reconhecer que a promoção de saúde é uma escolha possível para o exercício profissional, desenvolvendo estudos e pesquisas que, entre outros temas, dedicam-se a estudar o impacto da doença na vida das pessoas (Sebastiani, 2000).

É recente a importância dada ao papel do psicólogo no cuidado do paciente portador de doenças que não pertencem ao grupo das doenças mentais. No entanto, fica mais evidente a cada dia que o paciente com doenças físicas apresenta problemas de ordem psicológica que podem 
interferir no desenvolvimento da enfermidade, quando não interferem no próprio surgimento da moléstia.

Porcelli e Sonino (2007) relatam o desenvolvimento de um modelo denominado DCPR - Diagnostic Criteria for Psychosomatic Research, criado por um grupo de investigadores, baseado no reconhecimento de que evidências acumuladas na medicina psicossomática em relação à qualidade de vida, situações estressantes, desordens de personalidade entre outras, não eram ferramentas adequadas para o diagnóstico de determinadas síndromes.

A partir de respostas emocionais observadas, foram criados critérios que, por serem recorrentes, sugeriam aspectos psicológicos que estavam presentes nos pacientes portadores de diferentes doenças, comprovando, portanto a interferência de tais aspectos nos processos de adoecimento.

$\mathrm{Se}$, nas doenças em geral, os aspectos psicológicos ocorrem com frequência, no câncer eles tendem a ser mais evidentes e eventualmente prejudiciais.

Atualmente se estuda o surgimento de fatores emocionais em cada etapa da doença e a cada tipo de tratamento que é iniciado (Holland, 2002).

Atuar em instituições de saúde, muitas vezes, coloca o psicólogo em contato com questões que vão além da subjetividade individual, criando uma interface entre a psicologia clínica e a psicologia social, interface esta apontada por Spink (2000), que coloca a Psicologia da Saúde como área da Psicologia Social.

Embora não concorde com essa posição integralmente, sem dúvida considero que os problemas sociais estão presentes em muitos momentos do exercício da clínica nas diferentes formas de intervenção psicológica.

Se, no momento de sua redação a Lei 4.119 não contemplava o atendimento em instituições de saúde, consequentemente ignorava a 
função social do psicólogo (que emerge dessa prática, como expusemos acima).

Hoje, a função de agente transformador social é uma exigência que se impõe, além de ser uma demanda do próprio aluno do curso de psicologia. Cada vez menos frequentemente os alunos têm como proposta profissional o atendimento em consultório, em caráter individual. Cada vez é maior a procura por cursos de aprimoramento na área da Psicologia Hospitalar e da Saúde, como cada vez é maior a tendência por uma atuação menos individualizada, consciente das necessidades da comunidade em que vivemos.

Por ocasião da realização da disciplina por mim ministrada no programa de Pós Graduação do Departamento de Psicologia Clínica, denominada "Introdução à Psico-Oncologia: Possibilidades de intervenção junto ao paciente, a família e a comunidade", foi grande a procura, superando a expectativa por se tratar de área ainda não muito conhecida há quase 20 anos atrás.

Refletindo sobre minhas atividades, pareceu-me, naquele momento, que um trabalho que focasse a Psico-Oncologia poderia ser útil no sentido de serem divulgadas uma área e uma prática que ainda hoje podemos considerar recentes, como possibilidade de atuação do psicólogo.

O atendimento clínico a pacientes portadores de câncer, bem como a suas famílias e equipes de saúde, reveste-se de algumas características específicas.

Qualquer intervenção com pessoas acometidas de alguma enfermidade já requer do psicólogo que atua em áreas de promoção de saúde uma postura diferente daquela em que atua com pacientes sem doença física.

Se o atendimento implica cuidar de um paciente com câncer, certamente nos depararemos com alguns aspectos específicos, que não percebemos em pacientes com outras enfermidades. 
Também as famílias de uma pessoa acometida pelo câncer necessitam de ajuda psicológica, e mesmo as equipes de profissionais da saúde ligadas ao atendimento oncológico têm se revelado pacientes em potencial, pelo tipo de estresse a que ficam sujeitas ao longo do desenrolar da doença.

Em função de meu trabalho voltado para essa área há mais de 20 anos, o tema se impôs como sendo importante pelo fato de sua divulgação até hoje ter sido pouco desenvolvida junto à academia.

A Psico-Oncologia surgiu como sendo uma área de atuação importante a ser apresentada como um trabalho de Livre-Docência, não só como um trajeto pessoal, mas ainda com uma proposta de reflexão necessária para levar um leitor à sensação de que algo lhe foi acrescentado ao final da leitura.

Meu trabalho se propõe à apresentação desta área, como uma possibilidade de intervenção para o profissional de Psicologia, em terras até pouco tempo estranhas e de propriedade das ciências biológicas em geral, e da medicina em particular. Propõe-se ainda a expor trabalhos realizados e em andamento, pesquisas e publicações pertinentes, que são a base da constituição de um novo campo do saber. Sem esse acervo, o saber pode se transformar apenas em mais uma técnica, útil até, mas que não promove o desenvolvimento da área em questão como uma contribuição ao universo científico.

A Ciência, a cientificidade, a objetividade, exigidas por um trabalho de Livre-Docência também foram ponto de parada e reflexão sempre voltadas, evidentemente, para a Psico-Oncologia.

Afinal o que é ciência hoje? Quais os paradigmas com os quais nos deparamos na decodificação da natureza, e ainda da natureza humana?

Segundo Bronowski (1974, p.14), "a ciência está repleta de invenções feitas por homens cuja imaginação foi orientada pelos objetivos de que a sua época andava em busca". Ainda de acordo com o 
autor: "Aquilo que um cientista faz é composto de dois interesses: o da sua época e o seu próprio" (1974, p. 4).

Ou seja, é a necessidade de uma determinada época que dá forma ao progresso da ciência naquela mesma época.

Quais seriam então as necessidades que promoveriam um desenvolvimento cientifico no momento presente?

A natureza já foi suficientemente conhecida e dominada para que possamos abandoná-la como objeto da ciência?

Certamente não.

Mas quais seriam os interesses dos que pretendem fazer ciência hoje?

Em que lugar se colocariam as ciências da saúde, a Psicologia da Saúde, e por consequência a promoção de saúde e aqueles que a praticam?

A Psicologia padece de uma crise de identidade desde seu nascimento.

De um lado, é uma ciência humana, que tem como objeto o estudo das "estruturas dos desenvolvimentos, das operações da mente humana: consciência, vontade, percepção, linguagem, memória, imaginação, emoções" (Chauí, 1999, p. 276).

Mas, desde os estudos de Skinner, a Psicologia é colocada como ciência do comportamento, humano, animal, tornando-se uma interface da Biologia e atualmente da Neurociência, com as ciências humanas.

Em função de sua complexidade e dos diversos campos que abrange, a Psicologia entra na área da saúde formalmente com Freud, a partir da publicação dos Estudos sobre Histeria 1985 que demonstrava que "doenças" ocorriam sem nenhuma causa orgânica, chamando a atenção de médicos e pesquisadores para a probabilidade de uma interação entre mente e corpo, mais presente e constante do que poder-se-ia imaginar.

O surgimento da Psicossomática, por volta de 1939, nos Estados Unidos, vai comprovar a direção do pensamento de pesquisadores de 
diferentes áreas voltadas à promoção de saúde, todos aceitando a estreita interação mente-corpo, não necessariamente como causaefeito, mas como um continuum inseparável, mas passível de observação.

De acordo com Gimenes (1994):

a partir de então emerge o reconhecimento de que características peculiares a cada paciente, sua história, suas relações sociais, seu estilo de vida, seus processos mentais, sua personalidade e processos biológicos, precisam ser incluídos para se atingir uma conceitualização precisa de saúde e doença. (p. 39)

Se, até então, o modelo biomédico procurava dar conta do binômio saúde-doença, este passa a ser questionado por um novo modelo denominado Biopsicossocial.

$\mathrm{Na}$ verdade, o modelo Biopsicossocial aparece pela primeira vez na conferência de Alma Iata, no Pós II Guerra, e é formalmente estruturado a partir dos anos sessenta do séc. XX.

A partir de então, se criam as condições para que os aspectos psicológicos do câncer se tornem um campo estruturado do saber.

Ainda segundo Gimenes (1994), no início dos anos 70, nos Estados Unidos, é organizada uma área para estudar o lugar da Psicologia e dos processos emocionais no surgimento das doenças, embora os estados emocionais nos processos do adoecer já fossem objeto de estudo desde 1939, como citamos anteriormente.

Essa área, a Medicina Comportamental, tem como pressupostos os princípios da Psicologia Comportamental fundamentada no Behaviorismo Skinneriano e mostrou-se bastante efetiva para eliminar comportamentos nocivos à saúde como fumar, comer em excesso, e ainda na administração de estados de medo e ansiedade a partir de princípios relacionados a condicionamento e aprendizagem, entre outros. 
Ainda na década de 70, surge nos Estados Unidos aquilo que foi denominado de Psicologia da Saúde, que se propunha a utilizar o conhecimento científico e as práticas das diferentes áreas da Psicologia, para utilizá-las na promoção, prevenção e manutenção da saúde segundo a definição proposta por Matarazzo, a partir de 1980, citada por Ogden (2004):

o conjunto das contribuições específicas, educacionais, cientificas e práticas da disciplina da psicologia, para a promoção e manutenção da saúde, prevenção $e$ tratamento da doença e disfunções relacionadas. (p. 18).

Vemos que, a partir da confluência de várias áreas, todas com a proposta de entender o binômio saúde $\mathrm{x}$ doença, à luz de uma interação mente-corpo: Freud e a Psicanálise, a Psicossomática, a Medicina Comportamental, a Psicologia da Saúde, a comunidade científica passa a observar com mais cuidado as variáveis emocionais presentes ao surgimento e desenvolvimento das doenças em geral.

Voltando à questão colocada acima, sobre o lugar das ciências da saúde, e da própria Psicologia, parece-nos que, além das doenças mentais, surge um espaço para a melhor compreensão das doenças à luz dos processos psicológicos. Consequentemente nada mais natural do que o surgimento de uma ressignificação da prática clínica para os profissionais de psicologia a partir dessa nova visão.

O surgimento da Psico-Oncologia é influenciado por diversos fatores relacionados ao desenvolvimento das ciências, mas não deixa de ser uma necessidade que responde a uma demanda dos últimos anos, quando o câncer não para de atingir cada vez mais pessoas, levando as pesquisas a descobertas intrigantes, mas que em muitas vezes não explicam o surgimento e a evolução da doença. Como exemplo, citamos os casos em que não existem antecedentes na família, nem exposição a substâncias cancerígenas ou a alimentação pouco saudável ou outros fatores que sabemos podem gerar o surgimento de uma neoplasia. 
Situações emocionais que teriam gerado um estresse prolongado, falta de objetivos e razões para viver, perdas de familiares queridos e/ou esposo ou esposa, decepções com amigos antigos, aposentadoria forçada, são todos eventos que os próprios pacientes relacionam com o surgimento da doença.

Sabemos, no entanto, que existem pessoas que passam por essas situações sem adoecer ou sofrer qualquer dano físico, o que invalida uma relação causal nas situações citadas acima. O máximo que se pode afirmar é que existiria uma correlação entre situações estressantes e o surgimento de algumas doenças, entre elas o câncer.

Como psicanalista, sempre fui atraída no sentido de tentar entender as causas inconscientes e os discursos ocultos dos pacientes portadores de câncer. Não me parece possível a utilização da psicanálise strictu sensu como técnica no tratamento de um portador de qualquer doença, menos ainda do câncer, que deixa o paciente em um estado de profundo desamparo. Mas, sem dúvida, o domínio desse referencial permite a compreensão dos aspectos mais profundos das emoções e funcionamentos mentais do paciente de câncer, criando, portanto, melhores condições para a eficácia das intervenções nos atendimentos.

Embora não seja possível até hoje estabelecer uma relação direta entre o adoecer de câncer e os antecedentes emocionais, até o momento, após 30 anos de prática clínica, todos os pacientes portadores de câncer que entraram em meu consultório, no Laboratório Chronos, ou nos atendimentos em instituições de saúde, sempre diziam saber exatamente a razão de seu adoecimento.

A história da ciência é rica de exemplos onde o saber científico demonstrou que o "saber" do senso comum estava equivocado.

Uma coisa é o "saber do paciente", estabelecer uma relação entre uma situação e o desencadeamento da doença, e outra é colocar esse "saber" como etiologia da doença. Existem diferenças entre fatores etiológicos ou causais e fatores desencadeantes; o relato de situações 
de estresse ou correlação entre fatores de estresse e o surgimento da doença não permite o estabelecimento de um raciocínio etiológico, no máximo temos uma correlação temporal digna de ser destacada e pesquisada.

Os primeiros estudiosos das questões emocionais presentes nos pacientes de câncer, como LeShan (1989) e Simonton (1994), deram início a esse tipo de pesquisa que a Psico-Oncologia tem desenvolvido e ampliado.

Concluindo, ao refletir sobre fazer ou não fazer a Livre-Docência, percebi que, ao assumir tal decisão, o comprometimento com a instituição e o desenvolvimento pessoal passavam a um segundo plano face a uma responsabilidade individual pelo que seria escrito.

Surgiu um comprometimento, não mais com a academia, mas comigo mesma, no sentido de deixar registrada uma trajetória que passou por diferentes momentos, sempre visando à promoção de um conhecimento e de uma formação que fossem significativas para o indivíduo e para o profissional, fortalecendo, enriquecendo e marcando o lugar que o psicólogo ocupa na sociedade.

Tanto na carreira docente quanto no atendimento aos que se entregaram aos meus cuidados, acima de tudo esteve sempre presente o compromisso com a dignidade humana, além do bem-estar físico, espiritual e moral.

$\mathrm{O}$ atendimento clínico implica diversas facetas, que devem ser apresentadas à aprendizagem e reflexão dos alunos. Acredito que este trabalho possa contribuir para algum tipo de crescimento mental e intelectual, e principalmente reverter em algum bem para nossos pacientes, 0 verdadeiro motivo de toda uma carreira. 


\section{Introdução}

A clínica passa antes de tudo pelo olhar, pela linguagem, pela percepção.

Segundo Foucault (1963), a revisão feita pela Medicina em seus próprios valores e maneiras de enxergar a doença e o doente determinou uma mudança significativa na relação médico-paciente.

A Medicina baseada em evidências emerge como um método auxiliar para a realização de diagnósticos e tratamentos, no entanto não deixa de ser um conhecimento advindo de pesquisas em que os dados recebem um tratamento estatístico, o que nos leva a refletir sobre a questão de uma verdade estatística não ser necessariamente uma verdade humana e/ou clínica. Nem tudo é tão evidente quando se trata de ser humano, de indivíduo e do binômio saúde-doença.

A partir dessa visão, adotada por muitos, mas não por todos os médicos, um espaço novo se constituiu. O espaço para o emocional, para o psicológico na promoção de saúde, ou seja, no diagnóstico, no tratamento, prognóstico e prevenção.

A Psico-Oncologia trata desse espaço, dessa instância na Oncologia.

Na realidade, o que ocorreu em meados do séc. XX revolucionou o modelo até então utilizado para entender as doenças, o Modelo Biomédico.

Quando falamos de Modelo Biomédico baseado na Biologia, na Física, na Química, é importante frisar que nem sempre o mesmo foi utilizado no processo de entendimento da doença.

$\mathrm{Na}$ antiguidade, Hipócrates propunha uma Medicina que visse o homem como uma totalidade, onde mente e corpo funcionassem harmonicamente propiciando o bem-estar e a saúde. O rompimento dessa harmonia era o que trazia a doença. Os estados de humor poderiam ser responsabilizados por essa quebra de equilíbrio entre o corpo e a mente. 
Vale citar na íntegra o trecho de Lipowski (1984) relativo ao tema:

Desde os tempos de Hipócrates os médicos postularam que as emoções influenciam funções do corpo, e podiam causar doenças. O próprio Hipócrates costumava dizer "medo, culpa, prazer, paixão... a cada um destes o corpo responde por sua ação. Exemplos são os suores, as palpitações do coração". Uma afirmação similar pode ser encontrada em Aristóteles. Por séculos após Hipócrates, as emoções foram vistas não somente como tendo um efeito nas funções do corpo, mas também como fatores patogênicos. Galeno, séc. II d.C., um dos mais influentes médicos de toda a história, incluía as paixões entre as causas da doença somática que citava o sofrimento psíquico, a raiva, a luxúria e o medo como "doenças da alma", e deveriam ser diagnosticadas. Muito em função da influência deste autor a medicina europeia anterior ao século XIX devotava muita atenção à causa psicológica da doença em especial ao papel das emoções como fatores etiológicos em muitas doenças, incluindo as doenças contagiosas e as epidemias. (p. 153.)

Particularmente interessantes foram os comentários feitos por um médico alemão, Pechlin, em 1691, citado pelo autor acima, em relação ao papel desempenhado pelos fatores psicológicos no desenvolvimento e curso do câncer: "certamente um câncer, após a extirpação cirúrgica, em consequência do medo e da amargura, lentamente recrudesce e, após longa história de dificuldades, acaba pondo fim a uma vida" (Lipowski, 1984, p.153).

Tanto a Homeopatia como a Medicina Chinesa respeitam esses princípios, onde o rompimento de uma harmonia necessária à saúde é o responsável pelo surgimento da doença.

Apesar de não aceito pela Medicina clássica, os processos de intervenção por esse tipo de medicina remetem à busca desse equilíbrio que teria sido rompido, gerando a doença.

A história da doença no Ocidente mostra como a mente e o corpo foram sendo vistos como entidades separadas, e a doença mental passa 
a ser vista como danação demoníaca, enquanto a doença física tem em contrapartida a conotação de "castigo divino".

Já neste quadro podemos ver ambos, tanto o mal físico como o mental, revestidos de mitos e crenças, para os quais comportamentos supersticiosos poderiam levar à cura.

Nas culturas indígenas, os rituais do xamanismo propunham a extirpação do mal, para que a pessoa voltasse a ter saúde tanto física como mental.

No transcurso dos séculos, diversos autores assinalam que as questões da interação mente-corpo refletiam várias concepções, desde um dualismo interacionista, onde mente e corpo são substancialmente distintos, mas que interagem entre si e cujo principal representante seria Descartes, até concepções que se tornaram muito relevantes na segunda metade do século XIX, embora se possa localizar em Spinoza, para quem corpo e alma, extensão e pensamento, matéria e energia não seriam mais que atributos de uma "única, eterna e universal Substância", uma forma de monismo (Nobre de Melo, 1970).

Assim a história nos relata o pensamento de Hipócrates, Galeno, Pechlin e muitos outros, mas também podemos perceber movimentos bastante diversos, como por exemplo, em muitos períodos do século XIX, a concepção da mente como epifenômeno difunde-se vigorosamente, com um progressivo aprofundamento do conhecimento do cérebro e do sistema nervoso, com uma tendência a negar que a mente era função ou produto do cérebro. Se uma palavra sintetizasse a posição da medicina em grande parte do século XIX, essa palavra seria somato-psíquico (Stainbrook, 1952).

Essa cisão entre mente e corpo foi bastante reforçada pelo "Cógito" cartesiano, quando o corpo e a mente foram definitivamente separados, dando início à era da Filosofia Moderna e do racionalismo científico.

A partir de então, a medicina científica não podia dar espaço para nada que não fosse passível de observação e mensuração. Logo, 
processos mentais relacionados a estados emocionais não necessariamente patológicos não tinham lugar ou importância no processo do adoecer. O Modelo Biomédico baseado na Biologia na Física e na Química foi a consequência natural desse estado de coisas.

Com a publicação dos Estudos sobre a Histeria por Freud, no final do século XIX, algumas controvérsias têm início, quando a hipótese de que processos mentais pudessem interferir de tal modo no corpo, que teriam a capacidade de gerar doenças, observáveis, tais como cegueira e paralisia, sem que se encontrasse causa orgânica para tal.

A descoberta do inconsciente apresentada por Freud em suas publicações levantou questionamentos até então fora de qualquer discussão de caráter científico.

Nem toda a classe médica aceitou a proposição de Freud, e até hoje se discute a cientificidade da Psicanálise.

Ironicamente, a proposta de Freud era fazer uma Psicanálise científica, que observasse as leis de constituição de qualquer outra ciência, com um objeto, métodos de estudo e observação sistemática.

O objeto da Psicanálise é o Inconsciente, o método para se chegar a ele é a Associação Livre, mas tudo isso teria inevitavelmente que passar pela linguagem, pela capacidade de simbolização, sem as quais a Psicanálise não é possível.

Quando entramos no campo da linguagem, abrimos a porta de diferentes possibilidades de reflexão, como, por exemplo, quantas linguagens o ser humano é capaz de expressar, o que não cabe no momento.

No entanto, ao considerar os sintomas como uma linguagem a ser decodificada, abriu-se a possibilidade de introduzir o corpo como uma instância interligada a processos mentais inconscientes.

A Medicina Psicossomática vai estudar exatamente essas correlações.

O surgimento da Medicina Psicossomática, em meados do século XIX, só vem sedimentar uma discussão que já fora iniciada, propondo 
novas teorias sobre a relação corpo-mente como fator importante no processo do adoecer.

A partir desse momento, impõe-se a necessidade da criação de uma nova maneira de entender a doença e o homem. O Modelo Biomédico não era mais suficiente para tal.

Esse modelo é ampliado de forma muito significativa na Conferência Internacional de Cuidados Primários da Saúde, em AlmaAta, em 1978, na antiga URSS, que, dentre suas principais formulações:

enfatiza que a saúde - estado de completo bem-estar físico, mental e social, e não simplesmente a ausência de doença ou enfermidade - é um direito humano fundamental, e que a consecução do mais alto nível possível de saúde é a mais importante meta social mundial, cuja realização requer a ação de muitos outros setores sociais e econômicos, além do setor saúde. ${ }^{1}$

Essa concepção foi introduzida na Medicina Psicossomática, na década de 70 do século $X X$, através da inserção, da questão do social, na abordagem psicossomática. Dessa forma o Modelo Biopsicossocial emerge como consequência natural dessa situação, modelo este que pretende cobrir aspectos ligados à biologia, ao psiquismo e ao contexto social de surgimento da doença.

Essa perspectiva, desde que foi sustentada por George Engel, em 1977, defende a ideia de que os processos biológicos, psicológicos e sociais são envolvidos integralmente e interativamente na saúde física e na doença.

Para Engel (1977), a premissa inicialmente provocante de que as experiências psicológicas e os comportamentos sociais da pessoa estão relacionados de forma recíproca aos processos biológicos abasteceu avanços dramáticos na psicologia da saúde nos últimos 25 anos. Além disso, o pressuposto de que esses subsistemas estão aninhados e 
conectados inextricavelmente estimulou inovações no projeto e execução das intervenções para promover a saúde.

A introdução da variável "social" , como aspecto importante nos processos do adoecer, vem complementar uma "visão de homem" vigente até hoje, em que os fatores psicossociais são considerados essenciais no entendimento da doença e da saúde, sem desprezar os fatores orgânicos.

Existe uma infinidade de fatores, tanto de ordem emocional quanto psicossocial, como socioeconômica, que interferem no desenvolvimento de um câncer.

As repercussões psicológicas decorrentes do diagnóstico da doença motivaram os oncologistas a buscar um tipo de assistência para o paciente e seu familiar.

Posteriormente essa assistência se estendeu às equipes de saúde responsáveis por pacientes portadores da doença.

Vale lembrar que a "Síndrome de Burnout" ocorre com maior incidência em equipes de profissionais promotores de saúde ligadas aos cuidados com pacientes portadores de câncer.

Diversos trabalhos vêm sendo publicados relativos ao estresse em médicos, enfermeiras e outros profissionais da área da saúde, os quais demonstram cada vez mais a necessidade de um atendimento sistemático a estes profissionais (Caballero, M., Bermejo, Nieto \& Caballero, F., 2001; Ramirez, Graham, Richards, Cull, Gregory, Leaning, Snashall \& Timothy, 1995; Tucunduva, Garcia, Prudente, Centofanti, Souza, Monteiro, Vince, Smano, Gonçalves \& Del Giglio, 2006)

A Psico-Oncologia surge como uma consequência de diferentes fatores, sendo um dos mais importantes as observações que foram feitas por psiquiatras e assistentes sociais em enfermarias de pacientes portadores de câncer.

Esses pacientes apresentavam diferenças no desenvolvimento da moléstia, bem como na adesão aos tratamentos e na adaptação à 
mesma. Em alguns casos podia-se observar uma melhora considerável na qualidade de vida e na própria sobrevida.

A Psico-Oncologia nasce enfatizando os fatores psicossociais, biológicos e psicológicos no atendimento ao portador de câncer, e busca, assim, uma compreensão maior dos processos de adoecimento e desenvolvimento da moléstia, e por último os problemas de adaptação à doença, bem como as implicações na vida familiar, social e profissional dos portadores de câncer.

Nos últimos anos, além das instâncias biológica, psicológica e social, surgiu nos trabalhos dos psico-oncologistas uma preocupação com aspectos espirituais, não necessariamente presos a uma religião em particular, mas como uma forma de enfrentamento da moléstia. Nos casos mais graves, com possibilidade de morte próxima, isso é mais evidente.

De acordo com Holland (2002), o fato de ter que lidar com a crise existencial deflagrada pela doença e pela proximidade da morte faz com que muitas pessoas solicitem a presença de um ministro de sua religião.

A autora chega a afirmar que determinadas doenças têm sido chamadas de "crise psicoespiritual" (Holland, 2002).

É importante lembrar que ainda hoje o diagnóstico do câncer é visto por muitos como uma sentença de morte, como uma ameaça à estabilidade e à segurança do indivíduo e de sua família.

Muitas crenças e mitos cercam o câncer até hoje, o que contribui para que o medo e a desinformação passem a ocupar o imaginário das pessoas gerando angústia e desestabilizando seu equilíbrio psíquico.

$\mathrm{Na}$ verdade, a medicina avançou em sua luta contra as neoplasias malignas de tal forma que atualmente podemos afirmar que é uma doença não necessariamente fatal, podendo ocorrer remissões tão longas que o paciente pode vir a morrer de uma outra causa.

Contudo, nem sempre foi assim. 
Em um passado recente, o câncer era uma doença sem explicação, sem medicação que pudesse atingi-la e sem nenhuma possibilidade de cura.

As famílias que tinham um membro que estava com a doença passavam a se isolar, sem sequer pronunciar o nome da enfermidade. Resquício do pensamento mágico dos antigos, em que a evocação pela palavra podia trazer o mal que se temia.

A partir do início do século $X X$, algumas cirurgias tiveram sucesso na remoção de tumores, dependendo da extensão dos mesmos e da inexistência de metástases. Com o advento dos primeiros tratamentos por radioterapia e de algumas conquistas na área das medicações, as atitudes em relação ao câncer começaram a mudar.

Logo a seguir a quimioterapia mostrou sua eficácia no tratamento de tumores com metástases, levando a uma visão diferente do câncer.

Era o início de uma mudança importante em relação à doença, por parte dos médicos dos pacientes e da própria população.

É importante lembrar que não estamos falando de um período muito distante, mas das décadas de 30 e 40 do século XX.

Buron, Rodriguez, Linares e Lopez (2008) nos falam da mudança do prognóstico como um dos fatores que aumentaram o otimismo em relação aos processos de câncer, permitindo maior liberdade aos médicos para revelar o diagnóstico mais frequentemente do que até então.

A Psico-Oncologia teve espaço para se constituir a partir de diferentes fatores, mas certamente a informação ao paciente e ao familiar criou um outro tipo de relação médico-paciente, equipepaciente, equipe-família.

Não podemos esquecer que o reconhecimento de que distúrbios psicopatológicos e psiquiátricos, tais como ansiedade e depressão, poderiam influenciar no desenvolvimento da doença foi fundamental para a constituição dessa nova área. 
De acordo com Holland (2002), o atendimento psiquiátrico a partir dos pedidos de interconsulta vieram contribuir significativamente para o bem-estar do paciente.

Historicamente os psiquiatras encontraram muitas resistências para intervir junto a pacientes orgânicos de modo geral. Holland (2002) relata que as atitudes em relação à entrada de psiquiatras no hospital geral variavam de indiferentes a hostis.

Segundo a autora, alguns diretores de hospitais gerais chegavam a afirmar que a doença mental era uma doença sem esperança e que no seu hospital não havia lugar para insanos.

Apesar das resistências, ficou provada a importância da interferência do psiquiatra em relação à sintomatologia do paciente de câncer, não apenas naqueles relativos aos sintomas psiquiátricos tais como depressão, angústia e ansiedade.

Muitos medicamentos psiquiátricos tem influência comprovada na administração da dor, sendo utilizados em unidades de cuidados paliativos. Atualmente a comorbidade psiquiátrica não é mais vista como antes, tendo mudado radicalmente a postura geral.

A partir da aceitação de comorbidade psiquiátrica, necessidades existenciais, além das questões orgânicas e psicológicas, fizeram com que as equipes passassem a ver o paciente de maneira diferente.

A consequência natural de o paciente ser tratado como um todo é o aumento da Qualidade de Vida mesmo nos estágios finais da doença.

Uma das áreas mais enfatizadas na pesquisa em Psico-Oncologia nos últimos anos é a Qualidade de Vida do paciente, sendo que a interferência da psiquiatria muito colaborou para isso. Na verdade, a qualidade de vida tem sido mais importante do que a sobrevida propriamente dita.

Há alguns anos os profissionais promotores de saúde vêm buscando uma atuação conjunta, trabalhando de forma a compartilhar o tratamento dos pacientes, reconhecendo cada um seus limites, e utilizando o saber de uma outra área, como no caso das interconsultas. 
Estamos falando de uma atuação multidisciplinar, em que cada área contribui com o seu conhecimento no sentido de obter melhores resultados na luta contra a doença. E na melhora da Qualidade de Vida do paciente.

Há alguns anos, as instituições de saúde vêm discutindo a formação de equipes multidisciplinares, e, apesar de muitos hospitais já atuarem dessa forma, existe ainda muita resistência por partes dos próprios profissionais. A multidisciplinaridade vem acontecendo há já algum tempo, sem ainda ter ocupado todo o espaço que deveria ser o seu.

Resistência ao novo é um comportamento antigo, mas que ainda perdura, embora tenhamos que reconhecer que os modelos necessários estão ainda em construção, uma vez que implicam uma reformulação da maneira de pensar, mais do que na reformulação e aceitação dos diferentes discursos.

Em "A Religação dos Saberes", texto dedicado a publicar o resultado de suas "Jornadas Temáticas", Morin (2002, p.14) nos coloca face ao desafio da globalidade, ou seja, a inadequação de um saber fragmentado "[...] em elementos desconjuntados compartimentados nas disciplinas de um lado, e de outro entre as realidades multidimensionais, globais [...]". Enfim, nas palavras do autor, a ideia era menos confrontar os diferentes saberes, do que tentar uni-los sem atribuir mais ou menos valor a uma determinada área mas tentando o velho sonho de união entre as ciências humanas exatas e naturais. Cada uma com seu discurso, objeto e métodos próprios, com paradigmas diversos que dessem conta de cada área específica, sem perder de vista o objetivo primeiro que seria a vida humana em sua expressão mais elevada.

No mesmo texto, Ruffié (2002) propõe uma medicina que possa levar o homem a interagir com o médico, de tal forma que este último tenha o papel de determinar o que cada pessoa pode fazer para que 
fatores inatos e fatores adquiridos, que se complementariam na gênese de estados patológicos, jamais pudessem se encontrar.

$\mathrm{Na}$ realidade não só as neoplasias, mas outras doenças permanecem ainda longe de uma compreensão total para a medicina, gerando pesquisas e publicações no sentido de resolver os enigmas inerentes a elas.

Quando a Esfinge fala "Decifra-me ou te devoro", Édipo aceita o desafio. O câncer não deixa de ser ainda um desafio sob diversos aspectos, com características ainda desconhecidas a serem decifradas pelos pesquisadores.

Metaforicamente, os profissionais da Psico-Oncologia podem ser comparados ao jovem futuro rei de Esparta, pois propuseram-se a uma tarefa árdua, a uma sucessão de batalhas, nem todas ganhas, que é a tentativa de entender o câncer para melhor lutar contra ele. Embora atualmente muitos avanços tenham contribuído para maior entendimento do processo de surgimento e desenvolvimento de um câncer, muita coisa falta conhecer. O desenvolvimento dos estudos em genética, por exemplo, tem gerado trabalhos no sentido de uma provável prevenção em descendentes de portadoras de câncer de mama.

Okamura (1998) demonstra o impacto da medicina genética sobre o câncer, dando origem a três áreas distintas: Aconselhamento Genético, Diagnóstico Genético e Prognóstico Genético.

Profissionais treinados e com cursos de especialização com duração de dois anos em genética humana realizam sessões de aconselhamento sobre o risco do câncer. Após a sessão é feito um seguimento com a pessoa que a ela se submeteu no sentido de controlar efeitos estressantes em função do fato de serem discutidas abertamente as questões relativas ao eventual surgimento de um câncer.

O autor relata o desenvolvimento de atividades no Japão, na área da Psico-Oncologia, envolvendo treinamento de profissionais que 
possam distinguir aconselhamento genético de aconselhamento psicosocial, e ainda desenvolvem estudos sobre a criação de um modelo de atuação para aconselhamento genético em câncer. É importante o estudo de Coyne, Benazon, Gaba, Calzone e Weber (2000) mostrando que a utilização de questionários não alcança em profundidade as emoções despertadas pelo assunto.

Uma das discussões decorrentes de tais atividades é a que envolve as questões culturais em relação a países de cultura muito diferentes entre si, e os cuidados que devem ser tomados a partir dessa distinção.

Die Trill (1998) discute amplamente aspectos relacionados ao câncer, que variam de acordo com a cultura. Esta seria determinante da forma como os indivíduos portadores de um câncer vão lidar com a doença, o conhecimento do diagnóstico, os tratamentos e a adesão a eles, a dor e a eventual chegada da morte.

Segundo a autora, por exemplo, em relação à dor, os comportamentos variam desde demonstrações patológicas até o estoicismo, como no caso dos Baribas na África. Nessa tribo, demonstrar dor seria considerado fraqueza, e tem mais valor aquele que aguenta maior sofrimento sem demonstrar, não importando a origem do mesmo. Da mesma maneira, para algumas culturas a experiência do câncer deve ser vista como algo positivo, que pode ajudar no desenvolvimento individual, enquanto que, em outras, é considerada um mal, um castigo.

Ainda segundo Die Trill (1998), por esses exemplos, podemos verificar a importância de lembrar que a doença e os organismos não são apenas um amontoado de estruturas biológicas que se comportam de maneira que podem variar, mas, sim, indivíduos, com comportamentos culturais e individuais específicos a respeito dos fatos.

Em seus estudos, essa autora entrevistou grupos de médicos procedentes de diferentes países, constatando variações quanto à transmissão do diagnóstico ao paciente, ao familiar, às crianças. 
Os países que informam de maneira total e honestamente ao paciente, considerando esse comportamento um compromisso com a ética, são os Estados Unidos, a Austrália e a Holanda. No entanto, atualmente há uma tendência mundial para que se possa comunicar a verdade ao paciente portador de câncer.

No mesmo trabalho, Die Trill (1998) verificou diferenças na aceitação da chegada da morte, no papel que a família ocupa em relação aos cuidados com o paciente, e ainda em relação às crenças referentes às causas da doença.

O câncer sempre foi estigmatizado pela sociedade, e um diagnóstico poderia equivaler realmente a uma condenação semelhante à pena de morte. Não tínhamos notícias de causa conhecida para as neoplasias, e como consequência, sua cura era algo inimaginável.

Segundo Holland (2002), revelar o diagnóstico para um paciente era alguma coisa terrível e cruel, uma vez que se supunha que o mesmo perderia a esperança e a capacidade de lutar contra a doença.

Durante muito tempo, o tema "dizer ou não dizer" o diagnóstico ao paciente foi objeto de mesas redondas, conferências e pesquisas por parte dos oncologistas.

Apenas como ilustração, em atendimentos prestados ao longo da vida da autora deste trabalho vêm à lembrança muitos casos, e, aqui, a recordação contundente é a de uma senhora de aproximadamente 70 anos, que relatou, em atendimento psicoterápico, uma doença intestinal que havia tido, e que necessitou de uma cirurgia e de uma série de tratamentos posteriores à mesma, mas que ela tinha enfrentado muito bem, e finalmente havia ganho a guerra contra a doença. No entanto, dissera: "se fosse um câncer eu teria desistido porque a gente morre mesmo dessa doença, não é?". Vale dizer que ela estava em atendimento de caráter suportivo sem saber que havia tido um câncer de intestino que exigira uma cirurgia e quimioterapia por via oral.

Vale lembrar que saber ou não sobre a doença vai variar ainda de acordo com a estrutura de personalidade de cada indivíduo. Alguns 
relatam que, ao saber, ganharam forças para lutar e que isso deu um sentido às suas vidas durante a moléstia e posteriormente a ela.

A medicina contemporânea se abriu para diferentes modalidades de atendimento a pacientes de diferentes doenças. Existe uma tendência mundial no sentido de valorização da vida com qualidade, e não apenas de uma sobrevida indigna. Pacientes mantidos vivos ligados à parafernália tecnológica vêm sendo motivo de discussões na mídia a cada dia. Os próprios familiares vêm se confrontando com a questão de interromper uma vida artificial, sem quaisquer condições de recuperação das funções vitais mínimas.

Os estudos sobre eutanásia têm se desenvolvido, sendo tema de congressos, palestras e discussões que abrangem a Filosofia e o Direito, não se restringindo mais apenas à medicina.

Ética voltou a ser um ramo importante da Filosofia, a ser estudado e utilizado em diferentes situações ligadas ao avanço da ciência. A fertilização in vitro levou a situações que envolveram infinitas discussões sobre o que fazer com os embriões não utilizados.

As pesquisas com células-tronco, embora incipientes, já causaram polêmicas amplamente divulgadas, levando a população leiga a repensar seus valores. Questões como "o direito de escolher a própria morte", "o que fazer com embriões fertilizados in vitro,"manter o paciente em estado vegetativo" são questões que vêm aparecendo nas últimas décadas, paralelamente ao desenvolvimento das técnicas de prolongamento da vida, ou paradoxalmente do início da vida.

Segundo Segre e Cohen (1995, citado por Kovács, 2002):

a Bioética é o ramo da Ética que enfoca questões relativas à vida humana e à morte, propondo discussões sobre alguns temas, entre os quais o prolongamento da vida, morrer com dignidade, eutanásia, suicídio assistido... ( p.166) 
Não só a Bioética mas outras áreas relacionadas com as questões relativas à morte, ao cuidado com o paciente fora de possibilidades terapêuticas, ${ }^{2}$ ao alívio da dor, estão relacionadas com a PsicoOncologia, pois todas elas têm como objetivo comum o bem-estar do paciente ao longo e ao final da doença.

Pessini e Bertachini (2006) relatam que uma área que se preocupa com o paciente grave e com a sintomatologia de doenças consideradas terminais é aquela denominada Cuidados Paliativos.

A palavra "paliativo", do latim Pallio, significa cuidado, proteção, o Pallio é a cobertura, vista em algumas cidades menores, onde ainda existem as chamadas 'procissões", que vem carregada por algumas pessoas designadas anteriormente, com o objetivo de impedir que as intempéries possam atingir o ostensório onde se carrega o Santíssimo Sacramento.

Para Pessini e Bertachini, (2006), a definição de Cuidados Paliativos, pela Organização Mundial de Saúde, em 2002, é:

uma abordagem que aprimora a qualidade de vida, dos pacientes e famílias que enfrentam problemas associados com doenças ameaçadoras da vida, através da prevenção e alívio do sofrimento, por meios de identificação precoce, avaliação correta e tratamento da dor e outros problemas de ordem física, psicossocial e espiritual. (p. 169)

A Medicina Paliativa já é uma realidade em diferentes lugares do mundo, e, segundo esses autores, na Inglaterra já é uma especialidade médica desde 1987.

Impossível falar de Cuidados Paliativos sem uma referência a Cicely Mary Strode Saunders, criadora e diretora do St. Christopher's Hospice em Londres. Cicely Saunders é responsável pelo estabelecimento da disciplina e da cultura dos cuidados paliativos. E

\footnotetext{
${ }^{2}$ Expressão utilizada para designar o paciente que não tem mais condição de receber qualquer medicação ou intervenção médica.
} 
introduziu a noção de dignidade para as pessoas que estão morrendo, bem como a noção da importância da administração da dor dos pacientes. A Saunders devemos a criação da noção de "dor total", que inclui a dor física, emocional, social e espiritual. (Richmond, 2005).

Nosso objetivo neste trabalho é difundir, na academia, os conceitos que norteiam a Psico-Oncologia como uma nova área de conhecimento no atendimento ao paciente portador de câncer, seus familiares, equipes de saúde e à própria comunidade.

A partir de um relato histórico, pretende-se discutir o estado atual e as perspectivas dessa interface entre a medicina e a psicologia, além de um capítulo dedicado a uma reflexão sobre a metodologia possível, levando em conta a crise paradigmática que atingiu a contemporaneidade.

A justificativa para isso é a necessidade de um informe sistematizado, com reflexões críticas necessárias, uma vez que ainda é escassa a informação sobre a área.

Ao conviver com os benefícios que um atendimento fundado em conhecimentos da Psico-Oncologia promovem, tanto no paciente quanto em seus familiares e equipes de saúde, surgiu a necessidade de produzir algum conhecimento sobre tal vivência.

Atualmente os problemas da Psico-Oncologia residem nas pesquisas determinadas à construção de um modelo teórico tanto explicativo quanto intervencional. Além disso, o fato de ser uma atividade multidisciplinar gera questões relativas à identidade dos profissionais que atuam nessa área.

Quais as intervenções possíveis para cada profissão? Quais os limites de atuação de cada profissional de saúde que não extrapolem os respectivos códigos de ética?

Concluindo, o que não pode se perder é a visão sobre o câncer que a Psico-Oncologia construiu, uma visão diferente daquela que vigorou nas últimas décadas, com um otimismo fundado na constatação 
de que os avanços da medicina unidos ao cuidado integral do paciente mudaram a perspectiva de vida com qualidade para o mesmo.

Se falamos de "visão", voltamos ao início desta Introdução, quando citamos Foucault, na frase que abre o primeiro capítulo do Nascimento da Clínica, que agora parafraseamos:

"A Clínica passa, antes de tudo, pelo olhar". 


\section{A Hidra de mil cabeças: 0 Câncer}

We are not ourselves when nature, being oppressed, commands the mind to suffer with the body.

William Shakespeare, King Lear

\section{Aspectos Gerais}

O câncer é uma das doenças mais comuns em todo o mundo. Dados fornecidos pela Organização Mundial de Saúde informam que 15 milhões de pessoas são diagnosticadas como novos casos de câncer anualmente, destas, 8 milhões irão morrer em consequência da doença (Porcelli \& Sonino, 2007).

No Brasil, estudo desenvolvido por Cervi, Hermsdorf e Ribeiro (2005) mostrou que a mortalidade por neoplasia aumentou ao longo da série temporal (1980-2000), podendo se tornar a principal causa de morte no Brasil.

Em 2000, as neoplasias foram responsáveis por $12,73 \%$ dos 946.392 óbitos registrados no Brasil, sendo que 53,97\% dos óbitos por neoplasia ocorreram entre os homens e 46,01\% entre as mulheres. Em relação aos principais tipos de cânceres, destacam-se pulmão (12,4\%), estômago $(9,8 \%)$, mama $(7,3 \%)$, próstata $(6,5 \%)$, cólon e reto $(6,2 \%)$ e colo e útero (5,8\%) (Cervi, et al 2005).

É importante salientar que 20 milhões de pessoas estão vivendo com câncer ao redor do mundo. Esse aspecto é um dos dados que faz com que o câncer seja considerado atualmente como uma doença crônica, não necessariamente levando os portadores da doença à morte.

A comparação do câncer com o mito da Hidra de Lerna tem sentido em função da luta constante que é preciso manter para que um novo tumor não surja no lugar do anterior ou em outra parte do corpo. 
Citada pela primeira vez por Hesíodo, o monstro teria muitas cabeças que variavam de cinco a cem, sendo uma delas imortal.

Hoje, o câncer ainda pode ser visto como uma doença terrível como a Hidra, porém não podemos dizer que ressurja sempre. As metástases aparecem, são vencidas e o paciente pode ter longas remissões da moléstia, sem recidivas, por muitos anos, prolongando sua vida com qualidade. Algumas correntes falam em "cura", porém há controvérsias.

A alusão à Hidra de Lerna é mais no sentido do medo que a doença inspira, e a crença de que ela é invencível levando inexoravelmente à morte.

Apesar de não levar necessariamente à morte, como citamos anteriormente, o câncer é atualmente a segunda causa de morte no Brasil, perdendo apenas para as doenças cardiorrespiratórias.

A relação morbidade e mortalidade é desproporcional àquela observada nos países europeus ou da América do Norte. Essa disparidade reside no fato de no nosso meio, os exames preventivos e o consequente diagnóstico precoce serem ainda insuficientes e pouco utilizados pela população de modo geral, não importando a classe socioeconômica a que pertençam os doentes.

Fato importante a ser considerado ainda é que, até a bem pouco tempo, das mais de 126 escolas de Medicina reconhecidas pelo Conselho Federal de Medicina, poucas ministravam noções de Oncologia de forma isolada, como uma disciplina do currículo de graduação.

No que se refere à Pós-Graduação, existem poucas residências ou cursos especializados em Oncologia, o que cria o problema da desinformação da classe médica no diagnóstico e manejo do câncer.

Nas últimas décadas, observamos mudanças em relação a essa situação e o câncer tem sido uma especialidade bastante procurada como forma de especialização para recém-formados. A demanda ocorre tanto para a atividade clínica quanto para a cirúrgica. 
Na verdade, em função do grande número de casos que ocorrem anualmente, o câncer assumiu a característica de um "problema de saúde pública". O fato de não ser mais uma enfermidade que possa necessariamente levar à morte, resulta em um grande número de sobreviventes dependentes de tratamentos e medicações nem sempre acessíveis e disponíveis pelo sistema de saúde. O medo do diagnóstico, a desinformação em diferentes níveis, a falta de um sistema de saúde adequado, são apenas alguns dos fatores que contribuem para um quadro pessimista.

Várias campanhas são elaboradas, tendo como objetivo a mudança de hábitos que poderiam levar ao surgimento da doença. Contudo, os mitos e crenças que envolvem o câncer estão presentes não apenas na população leiga - algumas classes de profissionais promotores de saúde tentam não trabalhar diretamente ligados aos cuidados de portadores de câncer.

De acordo com trabalhos realizados pela Escola de Enfermagem da Universidade de São Paulo (Pimenta \& Kuizume, 1993), as crenças mais comuns apresentadas pelos estudantes das áreas de saúde estariam relacionadas com aspectos místicos, em que a religião seria o suficiente para a cura total da moléstia. Ainda de acordo com esses autores, a crença mais grave é a de que o câncer seria a sentença de morte para quem apresenta a doença e nada mais poderia ser feito.

Com o desenvolvimento da medicina, podemos dizer que, nos últimos 50 anos, têm surgido novos conhecimentos sobre o câncer com uma rapidez não conhecida até algumas décadas atrás. Não só as descobertas sobre a etiologia, mas ainda as técnicas de tratamento têm crescido em progressão geométrica.

Como resultado dessa expansão dos conhecimentos sobre a doença, podemos afirmar que, atualmente, o câncer pode ser considerado uma doença crônica e potencialmente a mais prevenível e até mesmo curável, se levarmos em conta, nessa afirmação, o tipo de 
tumor, o estádio em que é diagnosticado e a acessibilidade do paciente a tratamentos e medicações.

Evidentemente existe ainda uma porcentagem de tumores que, por sua constituição e forma de aparecimento, são fatais, embora possamos atualmente dar ao paciente alívio significativo dos sintomas e uma qualidade de vida que anteriormente era impossível de se imaginar.

\section{Histórico e características do câncer}

Galeno (130-200) d.C. foi quem construiu a primeira classificação dos tumores. Cabe ainda ressaltar que foi Galeno quem associou estados melancólicos em mulheres com o surgimento de formações tumorais.

Segundo Coelho (1998), o câncer tem sua origem coincidente com a história do próprio homem e é uma doença relacionada aos seus hábitos, cultura e fatores ambientais. Segundo esse autor, o primeiro a descrever a palavra "carcinos" e a definir o câncer como uma doença de mau prognóstico foi Hipócrates, em 500 a.C. Ou seja, o câncer sempre existiu na humanidade, não sendo uma doença nova.

$\mathrm{Na}$ verdade, mais de 200 doenças agrupam-se dentro da categoria que é denominada como câncer. Sua etiologia é complexa, sendo descrita como uma doença multifatorial e que surge a partir da mutação no código genético de apenas uma célula, que por sua vez se multiplica, dando origem a outras células anômalas que se agrupam gerando aquilo que será a massa tumoral.

Servan-Schreiber (2008, p.43), em trabalho autobiográfico após um câncer de cérebro, faz uma definição literária, mas verdadeira do processo de instalação de um câncer em um organismo: 
Tomado pelo câncer, o organismo vive uma guerra total. As células cancerosas se comportam como bandos armados sem fé nem lei, liberados das imposições da vida em sociedade que caracterizam um organismo em boa saúde. Com seus genes anormais, elas escapam aos mecanismos de regulação dos tecidos. Perdem, por exemplo, a obrigação de morrer depois de um certo número de divisões, tornando-se portanto "imortais". Fazem como se não escutassem os sinais dos tecidos circundantes que, alarmados pela falta de espaço, Ihe pedem incessantemente que parem de se multiplicar. Pior, estes se intoxicam pelas substâncias particulares secretadas pelas células cancerosas. Esses venenos criam uma inflamação local que estimula ainda mais sua expansão em detrimento dos territórios vizinhos. Finalmente, como um exército em campanha que precisa assegurar seu abastecimento, as células cancerosas requisitam os vasos sanguíneos das proximidades e os obrigam a proliferar a fim de fornecer o oxigênio e os nutrientes indispensáveis ao crescimento do que vai rapidamente se tornar um tumor.

Na verdade, a carcinogênese é um processo altamente complexo e seu desenvolvimento ocorre em múltiplas etapas. De acordo com Kowalski, Magrin e Carvalho (2002), as etapas são: indução, promoção, transformação e progressão tumoral. A indução seria a ação direta de um elemento carcinógeno sobre o DNA ocasionando mutações e alterações nos genes. Na fase de promoção e transformação, os clones da célula sofrem múltiplas alterações. O grande problema, segundo esses autores, é que a história natural da doença pode durar cerca de 30 anos e ocorre de maneira sub-clínica, sendo portanto de difícil diagnóstico. Quando não são diagnosticados nas fases iniciais, préinvasivas, os tumores evoluem e comprometem as estruturas adjacentes, espalhando-se pelos linfonodos ou órgãos mais distantes.

Apesar da relativa facilidade com que atualmente alguns tipos de cânceres podem ser diagnosticados, muitas vezes a massa tumoral pode chegar a $2 \mathrm{~cm}$. De acordo com Kowalski, Magrin e Carvalho (2002), esse fato é decorrência da ignorância e falta de informação da população sobre a doença e seus sintomas. Evidentemente existem os 
tumores que não são percebidos a não ser por um "achado de exame" ou quando já é tarde demais.

Uma das grandes dificuldades no diagnóstico do câncer é a correta interpretação de sintomas que podem ser confundidos com outras doenças. Daí a necessidade de um especialista ser consultado, além do preparo e da informação dos clínicos em geral.

Grande parte das neoplasias malignas são atribuídas a influências ambientais, particularmente aquelas relacionadas ao estilo de vida do paciente. $O$ exemplo mais citado nesse caso é a correlação fumo-câncer de pulmão, juntamente com hábitos alimentares e câncer de intestino, entre outros.

De acordo com Schmitt (1991), neoplasia significa novo crescimento e este novo crescimento é o "neoplasma". Ainda segundo esse autor, há inúmeras definições de neoplasia, mas uma das mais aceita é a que afirma que o neoplasma "é uma massa anormal de tecido cujo crescimento é excessivo e desordenado, continuando a crescer mesmo após o estímulo que a provocou" (p. 44) A esta massa se dá o nome de tumor.

O câncer ou as neoplasias malignas, em geral, apresentam ulcerações e necroses, enquanto que as neoplasias benignas apenas apresentam-se na forma de uma massa tumoral não invasiva.

Atualmente, ao diagnosticar um câncer, dizer que um tumor é benigno ou maligno não é o suficiente. É preciso dizer qual o tipo de agressividade do tumor, isto é, o grau de invasibilidade que o mesmo pode ter em relação aos tecidos vizinhos.

Outra característica dos tumores é a capacidade de criar uma rede de vasos sanguíneos à sua volta para que possam ser alimentados; a este quadro dá-se o nome de angiogênese e pode ocorrer em outras situações clínicas. No câncer, uma das possibilidades de tratamento atualmente é impedir ou paralisar a criação dessa rede de vasos para que o tumor não tenha do que se alimentar. 
Um câncer pode surgir em qualquer órgão ou tecido humano, sendo a sua malignidade decorrente do tipo de células da qual é composto. Por exemplo, o melanoma, tumor de alta malignidade, tem um prognóstico bastante positivo, não chegando a ser letal se surgir na pele de um indivíduo. Tumores constituídos por células epiteliais são em sua maioria pouco malignos e apresentam em geral um prognóstico bastante positivo.

Além de fatores ambientais, um câncer pode surgir a partir de uma lesão, de um processo inflamatório e seu desenvolvimento é bastante lento, sendo assintomático e sub-clínico, o que dificulta seu diagnóstico precoce.

Hoje, apenas $30 \%$ dos tumores são fatais, levando a óbito, sendo os $70 \%$ restantes tratáveis, transformando-se em doenças crônicas com sobrevida significativa.

Metástase é o nome que se dá a um novo tumor, constituído a partir de uma célula que tenha se desprendido do tumor denominado "primário" através da circulação. Um tumor primário pode originar diversas metástases. Além do tumor primário, em um mesmo indivíduo, pode surgir um novo tumor, que não é metástase na medida em que é constituído por outro tipo de célula e com outras características que o diferenciam do chamado tumor "primário". Nem sempre é possível identificar a origem e localização do tumor primário, o que dificulta o tratamento.

\section{Diagnóstico do câncer}

Em qualquer doença o diagnóstico é fundamental para uma abordagem terapêutica adequada. No caso do câncer, além dos sintomas clínicos que são colhidos na anamnese, do exame físico realizado pelo médico e da interpretação correta desses dados, os exames complementares são essenciais, pois podem confirmar o diagnóstico e indicar o estadiamento do tumor. O exame histológico é 
importante e esclarecedor, pois dele dependem o planejamento terapêutico e o prognóstico.

Além do diagnóstico por exaustão e o hipotético dedutivo, os profissionais oncologistas podem contar com a biópsia, que, de acordo com Kowalski (1998), é o exame por excelência, porém nem sempre possível, pois vai depender da localização do tumor.

Atualmente existem exames que denunciam a existência de tumores, a partir dos chamados "marcadores tumorais", através do exame de sangue. Os marcadores tumorais, segundo Anelli e Noronha (2002), são características particulares, mas não exclusivas das células tumorais. Podem aparecer sob a forma de substâncias liberadas na corrente sanguínea aparecendo, portanto, em exames de sangue voltados para o diagnóstico de um câncer.

Além desses, existem os diagnósticos por imagem, que em geral podem ser utilizados como complementares a outros exames já solicitados aos pacientes.

Como podemos perceber, é necessária uma rede de atenção básica à saúde acessível para a população. Não só isso é difícil, como sabemos em nossa experiência clínica que o prazo de agendamento de um exame pode ser tão longo que o agravamento da doença pode transformar um prognóstico que poderia ser bom em um prognóstico bastante negativo, exigindo já intervenções só possíveis em um hospital de especialidades onde a mesma problemática de demanda infinitamente superior aos recursos se repetirá num círculo vicioso.

Como vemos, ao adentrar o hospital e participar das questões de saúde, o psicólogo é chamado a refletir sobre questões da ordem do social, o que nos coloca face a uma realidade dolorosa que desafia o poder público no sentido de encontrar as soluções possíveis para tal quadro. Um dos problemas de "saúde" no Brasil é um problema social e não mais médico. 
A Psico-Oncologia vem discutindo essas questões em seus cursos de formação, uma vez que o profissional dessa área deve estar a par do contexto político-social que envolve o câncer.

\section{Tratamentos convencionais contra o câncer}

Até o início do século XIX, a única forma de tentar a cura do câncer era a cirurgia. Geralmente essa técnica de erradicação da doença era malsucedida, em função da ausência de anestésicos adequados, o que dificultava uma erradicação mais profunda e, portanto, mais eficiente. Além disso, as condições de assepsia não eram as melhores, o que propiciava infecções que prejudicavam o pósoperatório, podendo o paciente vir a morrer em conseqüência não mais do câncer, mas de outros fatores.

A partir de meados do século XIX, os anestésicos foram se aperfeiçoando e a radioterapia começou a ser usada no tratamento do câncer, seguida dos quimioterápicos, passando-se a utilizar aquilo que se denominou "técnica tríplice", que consistia na utilização da quimioterapia para a redução do tumor, seguida de cirurgia e de radioterapia para impedir novas formações ou metástases.

Atualmente, são inúmeras as formas de se lutar contra o câncer e, embora os tratamentos sejam bastante invasivos, o índice de sobrevida à doença tem aumentado a cada ano.

Infelizmente, os tratamentos têm efeitos colaterais dolorosos que geram profundo desconforto nos pacientes, levando a manifestações de comportamentos que merecem a atenção, uma vez que podem incluir estados ansiosos, depressivos, dolorosos, o que por sua vez resultarão em manifestações emocionais diversas, que até as últimas décadas não eram levadas em consideração como aspectos a serem cuidados.

A partir de movimentos de humanização do atendimento do paciente de câncer, da evolução da Psicologia e da entrada do psicólogo 
nas instituições de saúde, os aspectos emocionais do paciente passaram a ser considerados como uma faceta importante a ser cuidada.

A medicina paliativa tem tido papel importante na melhora das condições de qualidade de vida de pacientes graves em geral, e particularmente no cuidado do paciente de câncer. Cabe à medicina paliativa a administração dos diferentes sintomas que acompanham o desenvolvimento da doença, como por exemplo, a dor, a náusea entre outros.

Cabe a Psico-Oncologia o cuidado com os aspectos de natureza psicológica desencadeados pela doença e seus tratamentos. A cada tratamento correspondem comportamentos emocionais distintos, que atualmente são estudados e acompanhados por essa área.

Além das diferentes reações que cada tratamento suscita, é necessário levar em conta as diferenças pessoais, o que gera diferentes tipos de enfrentamento.

Vemos, portanto, a complexidade que existe nesse tipo de atendimento. Cada paciente é um paciente, reagindo à sua maneira e enfrentando a doença e suas consequências de sua forma particular.

Importante lembrar que, além dos tratamentos tradicionais que passamos a descrever de maneira sucinta, muitos pacientes optam por tratamentos alternativos nos quais se incluem a homeopatia, a antroposofia, a medicina chinesa, entre outros.

Não nos propomos a discutir a eficácia de um ou outro tratamento, apenas podemos observar que alguns pacientes que optam por tratamentos não tradicionais também apresentam melhora significativa. Nesses casos, poderíamos levantar a hipótese da importância da relação do paciente com seu médico, sua medicação, e suas crenças em determinados tratamentos.

Uma das alegações dos pacientes por essas opções diz respeito aos efeitos colaterais da radioterapia ou da quimioterapia. Em nossa experiência, vemos muitas vezes um mecanismo de negação evidente quando surge a proposta pelo paciente de procurar tratamentos 
alternativos. Parece ser mais fácil e menos violento evitar os tratamentos tradicionais da medicina ocidental, em geral desconfortáveis e dolorosos.

No entanto, muitas vezes o paciente opta pelos tratamentos alternativos em uma fase em que seria possível algum sucesso no sentido de evitar o progresso da doença. Ao voltar atrás em suas decisões, muitas vezes o câncer já se desenvolveu de tal forma que não é mais possível intervir de maneira a tentar a paralisação do desenvolvimento da doença.

Em nossa experiência, não nos propomos a impedir a utilização de tratamentos alternativos quando podem agir de maneira paliativa, tais como nutrição adequada, acupuntura para alívio da dor e do desconforto, relaxamento etc. O que não indicamos é a troca dos tratamentos comprovadamente eficazes por outros que não possuem embasamento científico.

\section{Radioterapia}

É um dos primeiros tratamentos que passaram a ser utilizados na luta contra o câncer. De acordo com Yamaguchi (1994), consiste na emissão de partículas radioativas que são direcionadas para a área do tumor e podem atuar na diminuição de seu tamanho, na eliminação ou melhora da sensação dolorosa e algumas vezes até na cura, dependendo do estágio e do tipo de tumor contra o qual é utilizada. Existem tumores que são refratários à radioterapia e nesse caso a mesma é utilizada apenas na diminuição da sensação dolorosa. Vários compostos radioativos são utilizados a partir de uma fonte externa ou interna, e o conhecimento de cada um deles deve ser do domínio daquele que o utiliza. Existe ainda a possibilidade de ser colocado um implante radioativo, que tem sido utilizado em algumas situações, por um determinado período de tempo. 
Os efeitos colaterais desse tipo de tratamento fazem com que os pacientes muitas vezes se recusem a se submeter a ele. Isso gera um conflito entre equipes de saúde, familiares e pacientes. A questão do tempo surge como imperativo, uma vez que, não sendo administrado no tempo mais rápido possível, o tratamento pode não ter os efeitos desejados. Citamos esse exemplo apenas a título de ilustração das questões que dizem respeito ao câncer, seus tratamentos e seus pacientes.

\section{Quimioterapia}

Quimioterapia é o nome pelo qual se designa o tratamento por substâncias químicas em qualquer doença. No entanto, por sua utilização frequente nos casos de câncer, ficou conhecida como um tratamento específico para câncer, esquecendo-se que pode ser utilizada em outras doenças.

$\mathrm{Na}$ verdade, sua utilização data dos últimos 40 anos e as medicações utilizadas vêm sendo aperfeiçoadas com a intenção de minorar os efeitos colaterais presentes nesse tipo de intervenção.

Os efeitos mais freqüentes são náusea, vômitos, mal-estar, fraqueza, cansaço, e perda de cabelo. Os potentes componentes dos quimioterápicos podem atingir o bulbo capilar fazendo com que ocorra a queda dos cabelos durante o período do tratamento. As reações podem variar de paciente para paciente, não podendo, portanto, ser generalizadas para todos os casos.

Uma curiosa observação a partir da prática clínica é o caso das mulheres que, ao verem indicado o tratamento quimioterápico, passam a se preocupar com a queda dos cabelos, chegando a esquecer momentaneamente a doença, talvez por um mecanismo de deslocamento, em que a perda dos cabelos adquire importância maior do que a própria doença. 
A náusea, a falta de energia e o mal-estar generalizado aparecem após dois ou três dias da aplicação do medicamento. Novamente, as reações podem variar de pessoa para pessoa bem como a maneira de cada uma lidar com as mesmas.

\section{Imunoterapia}

A partir do surgimento da AIDS, as pesquisas a respeito do sistema imunológico se intensificaram. Este sistema tem a finalidade de defender os organismos de ataques externos e internos que podem causar doenças.

A todo momento podem surgir infecções, ocasionadas por elementos externos ou não, que podem ser melhor combatidas se nosso sistema imunológico responde adequadamente. Segundo Yamaguchi (1994) esse sistema está intimamente ligado ao sistema neuroendócrino e existe uma interação constante entre ambos.

O sistema imunológico é formado por diferentes tipos de células com o mesmo objetivo: defender nosso organismo de doenças inflamatórias, infecciosas e de qualquer tipo. Não só as células, mas ainda substâncias produzidas por elas podem agir protetoramente impedindo muitas vezes as doenças de se instalar ou ainda dificultando sua progressão. Na verdade, a reação de cada indivíduo às doenças depende do sistema imunológico, mas também de outros fatores, sendo, portanto cada reação única e individual.

Um dos grupos responsáveis pelo ataque a células anômalas em nosso organismo é constituído pelas células denominadas NK, que são as iniciais de "Natural Killer". O papel dessas células é identificar e destruir células anômalas em geral e neoplásicas em particular.

Em função de sua interação com os sistemas nervoso e endócrino, pudemos comprovar que estados de ansiedade, nervosismo, depressão 
e cansaço físico interferem na produção dos NK, e podem ser nocivos para o sistema imunológico como um todo.

Uma das experiências mais conhecidas e que comprova a importância do sistema imunológico na incidência do câncer é a observada em pacientes submetidos a transplantes de medula óssea, ou outros órgãos, que tomam imunodepressores para que não haja rejeição do receptor ao transplante. Nesses pacientes, a incidência de câncer é 40 vezes maior do que na população em geral (Yamaguchi, 1994).

Existem muitos protocolos em andamento para testar substâncias que seriam importantes para o fortalecimento do sistema imunológico. Ainda segundo Yamaguchi (1994), uma das experiências que podemos citar, à guisa de exemplo, é a fabricação de anticorpos monoclonais, ou seja, anticorpos fabricados fora do corpo cujo alvo seriam os tumores e outros componentes do sistema imunológico.

De acordo com Yamaguchi (1994, p.29):

(...) papel importante vem sendo desempenhado pelos derivados de vitamina $A$, os chamados retinoides, na prevenção de outros tipos de câncer, nos pacientes que já tenham apresentado cânceres de cabeça e pescoço, alem de já ser possível tratar algumas lesões pré-cancerosas de boca e câncer de pele com essa medicação.

Não podemos esquecer que cada indivíduo possui um sistema imunológico próprio de sua constituição, onde entram não só seu código genético, como outros fatores herdados e que influenciam a reação do organismo a doença.

Importante lembrar o Projeto Genoma Humano (Human Genome Project, HGP) que segundo Caballero \& Simpson (2002) é um esforço internacional para elucidar e caracterizar a seqüência dos pares de bases do genoma humano. Segundo estes autores isto vai revolucionar a prática da medicina no século 21. A partir das descobertas deste projeto poder-se-á prever o componente genético de virtualmente todas 
as doenças. Segundo os autores, "as conseqüências para a prática da medicina deverão ser profundas, tais como a geração de medidas que possam prever o risco, permitir o diagnostico precoce e promover estratégias de tratamento mais efetivas" (pág 49).

Não iremos descrever todos os tipos de tratamentos possíveis para a doença, pois fugiria aos objetivos restritos deste trabalho, mas lembramos que a cada dia surgem mais possibilidades de vencer 0 câncer, a partir das descobertas de novos tratamentos ou da combinação dos anteriores.

\section{Oncologia Pediátrica}

Confirmando o que dissemos no último parágrafo, Bianchi (2002) nos lembra que "todo manual de conduta diagnóstica e terapêutica existe com" prazo de validade ", de acordo com a "data de fabricação".

O autor nos lembra que, no caso da oncologia pediátrica, a biologia molecular, a genética e seus achados vêm oferecendo subsídios importantes para o diagnóstico mais rápido das neoplasias.

Ainda segundo Bianchi (2002), esse fato tem praticamente obrigado a elaboração de novos protocolos diagnósticos e terapêuticos a cada dois a quatro anos. Protocolos estes altamente eficazes para o autor, e que levam à remissão de aproximadamente $70 \%$ dos casos de câncer infantil.

Embora nem todos os casos tenham uma explicação conhecida com um diagnóstico rápido e uma terapêutica eficaz, podemos supor que, em alguns anos, o índice de remissão do câncer na infância deva aumentar ainda mais.

Infelizmente, em função da própria velocidade do desenvolvimento da Oncologia Pediátrica não podemos prever com exatidão todos os efeitos das chamadas poliquimioterapias, efeitos estes que podem surgir até 15 anos após a sua administração. 
Diferentes tipos de câncer podem atingir a população ainda em idade precoce, sendo os mais comuns as leucemias, o retinoblastoma, a doença de Hodgkin e suas variações, os tumores do sistema nervoso central, os tumores hepáticos, o osteosarcoma, entre outros.

Uma das formas mais frequentes da doença, as leucemias possuem um índice de remissão bastante alto, e, além disso, deram origem à técnica de transplante de medula óssea, importante forma de tratamento em uso no Brasil desde a década de 80 passada. Embora bastante invasiva e com efeitos colaterais bastante desconfortáveis para o paciente, apresenta um índice de cura bem alto, em função da substituição da medula doente por uma saudável, doada por um doador compatível ou pelo próprio paciente em período de remissão. Atualmente se utiliza a técnica do transplante de medula óssea também para outros tipos de tumores malignos, com índice bastante alto de remissões de longa duração.

Apesar dos muitos prognósticos benignos dos cânceres na infância, é imprescindível que a deteç̧ão do tumor seja precoce, bem como o diagnóstico cuidadoso, uma vez que os sintomas podem ser confundidos com os de outras doenças.

Em relação à Psico-Oncologia, o câncer infantil é uma das formas da doença que exige diferentes intervenções junto à equipe. Mobilizam sentimentos fortes de impotência, aliados à frustração de observar que o paciente está morrendo apesar de todos os esforços feitos. A presença imprescindível dos pais, também necessitados de toda ajuda, leva à necessidade da presença de vários profissionais psicooncologistas atuando nas divisões de Oncologia Pediátrica.

Além dessas constatações, vale lembrar que, ao ser internada para um tratamento, a criança tem interrompidas suas atividades escolares, o que leva muitos hospitais a criarem espaços que possam minimizar essa perda.

Alguns hospitais possuem grupos de voluntários ou profissionais que são verdadeiras escolas "itinerantes", como é o caso de diferentes 
Grupos de Apoio a Crianças com Câncer, cujos voluntários atuam em salas de atendimento, salas de espera e outras dependências.

Esse é apenas um dos aspectos psicossociais que envolvem o adoecer por câncer na infância. A Psico-Oncologia vem tentando minimizar as perdas de diferentes graus de intensidade e gravidade que atingem a criança que vem a desenvolver um câncer. Algumas podem ser minoradas, mas existem grupos estudando como vão se desenvolver os sobreviventes a um câncer, suas sequelas físicas, emocionais e psicossociais.

Oeffinger e Hudson (2004, citado por Perina, Mastellaro \& Nucci, 2008), realizaram extensa revisão de estudos relatando os efeitos tardios da terapia do câncer. Em outro estudo Oeffinger, Mertens, Sklar et. al. (2006, citado por Perina, Mastellaro \& Nucci, 2008) fizeram outro estudo mais amplo, com 10.397 pacientes portadores de câncer tratados no período de 1970 a 1986 que sobreviveram. Verificaram que, mesmo decorridos 30 anos do final dos processos terapêuticos, três quartos dos pacientes desenvolveram algum problema crônico de saúde e que um terço dos pacientes estudados apresentaram múltiplos efeitos tardios relacionados à saúde.

Muitas pesquisas ainda em protocolo visam gerar subsídios para um atendimento mais eficaz tanto das crianças, como dos adolescentes que tiveram um câncer na infância, com eventuais mutilações, por exemplo. Esse tipo de problema é parte dos interesses do SIOP Sociedade Internacional de Oncologia Pediátrica.

Perina, Mastellaro e Nucci relatam (2008) que não só o paciente como pais, médicos e familiares necessitam de orientações claras para saber o que devem esperar dos próximos anos, um efeito tardio, que por sua vez pode trazer seqüelas.

Ainda segundo esses autores, um programa de acompanhamento aos pacientes e familiares poderá dar a oportunidade de muitos esclarecimentos sobre a doença que enfrentaram. E ainda poderá educá-los quanto aos riscos relativos as sequelas. 
Ou seja, nunca um paciente que um dia teve um câncer deve deixar de ficar atento a qualquer tipo de possibilidade de aprender sobre a doença e se atualizar sobre novos tratamentos e medicamentos que forem surgindo.

\section{Aspectos Éticos}

Do diagnóstico à eventual morte, o atendimento ao paciente portador de câncer e a seus familiares implica aspectos éticos difíceis e particulares. Em todas as doenças, a relação médico-paciente, pacienteequipe, equipe-família, tem características próprias do quadro, do entrosamento da equipe, da personalidade do paciente, da estrutura do grupo familiar.

As etapas a serem acompanhadas pelo médico e equipe são: o diagnóstico, as decisões do tratamento, o prognóstico, a terminalidade.

No caso do diagnóstico, sempre está envolvida uma carga de preconceitos e ignorância que cercam usualmente o câncer. É importante que o profissional a apresentar o mesmo seja sempre o médico, eventualmente assistido por outro membro da equipe, de preferência o profissional de psico-oncologia. Em hipótese alguma essa tarefa deve ser transferida para outro membro, pois caberão sempre ao médico as decisões sobre o restante do tratamento da doença.

É uma fase muito difícil para a família, e considerada a mais desestruturadora. Ribeiro (1994), ao discorrer sobre o paciente terminal e sua família, propõe três fases pelas quais passam o paciente e a família atingidas pelo câncer. A primeira fase é o momento do Diagnóstico, denominada Fase Aguda, quando o paciente e seus familiares sofrem o choque emocional causado pelo diagnóstico Ocorrem momentos em que um dos elementos da família pode apresentar um "stress" maior do que o próprio paciente. A segunda fase é a fase crônica onde os comportamentos vão ficando mais estáveis, 
onde os tratamentos podem ter se iniciado, e surge alguma esperança em relação ao desenvolvimento da doença $A$ terceira e última fase é a da resolução onde ocorre a morte ou o paciente é considerado em fase de remissão, e passa a ser um sobrevivente.

Em relação ao que deve ser comunicado ao paciente, todo cuidado é pouco, em termos "do quê" será comunicado, "a quem mais" será comunicado e "o quanto" será comunicado.

No Brasil, é preciso levar em conta a cultura, a classe socioeconômica e o estado emocional em que se encontra o paciente, dosando a informação de acordo com essas variáveis. Muitos médicos seguem a escola americana, informando detalhadamente ao paciente o estádio em que a doença se encontra e formulando um prognóstico bastante negativo com "prazos" de vida etc. Isso até pode acontecer, mas sempre levando em conta o que citamos acima.

Em nosso modo de ver e, a partir do exercício da Psico-Oncologia, é cada vez mais difícil prever a evolução de um paciente, pois as variáveis individuais de personalidade e consequente maneira de enfrentamento vêm comprovando a inviabilidade de uma previsão muito exata.

Além do diagnóstico, a opção pelos tratamentos também envolve aspectos éticos, em função da disponibilidade financeira do paciente, da assistência que o mesmo pode ter em relação aos custos etc. Mas sempre devem ser apresentadas diferentes possibilidades, quando as mesmas existirem. O médico e a equipe devem ser orientados no sentido de ajudar o paciente a optar por aquilo que é necessário e indispensável.

Muitas vezes a família pode ser contra alguma forma de intervenção, algumas vezes por não conhecer exatamente a eficácia da mesma. Nesse caso, principalmente o médico terá importância fundamental na orientação do caso. 
$\mathrm{Na}$ terminalidade, toda a equipe tem função importantíssima, pois todos encontram-se atingidos, paciente, família, médico e a própria equipe.

As decisões sobre a insistência em administrar tratamentos que talvez não tenham mais razão de ser, a questão da manutenção de uma vida artificial, a interrupção de medicação, a permanência em U.T.I., são algumas das variáveis que devem ser cuidadosamente estudadas e, de preferência, discutidas com o profissional da Psico-Oncologia. A própria discussão em equipe pode ajudar muito no estresse causado por esses eventos. Nesse momento, a multidisciplinaridade mostra sua importância, servindo de espaço para que todos possam partilhar suas dúvidas, angústias e medos.

A Psico-Oncologia não tem deixado de lutar para que haja, por parte dos governantes, sistemas de saúde que promovam educação para a prevenção, para o diagnóstico precoce e o respeito pela individualidade, uma vez que estamos sempre lidando com um único indivíduo: o paciente de câncer. 


\section{Psico-Oncologia: histórico}

Living with Hope

Coping with Uncertainty

Jimmie Holland

\section{Antecedentes}

Como já foi dito, historicamente diferentes eventos e acontecimentos criaram um campo fértil para o surgimento da PsicoOncologia, o desenvolvimento da psicologia, da psiquiatria e da medicina.

Há aproximadamente 40 anos, essa área produziu um modelo no qual o domínio psicológico foi integrado como uma subespecialidade da oncologia por sua criadora. No Brasil, a Psico-Oncologia é definida como a área que seria uma interface entre a Psicologia e a Oncologia (Gimenes, 1994).

Hoje este campo contribui para o desenvolvimento dos cuidados clínicos de pacientes e familiares, além de treinar staffs na administração dos aspectos psicológicos que surgem em decorrência do estresse gerado pelo atendimento de pacientes portadores de câncer, e ainda na produção de pesquisas, na criação de programas de prevenção e mesmo na terminalidade.

Causa certa estranheza para Holland (2002) que a PsicoOncologia só tenha início por volta dos anos 70, em função dos diversos aspectos psicológicos que envolvem o paciente portador de câncer. O aparecimento dessa área só foi possível a partir da constatação de que o estigma que envolve essa doença diminuiu, possibilitando mudanças de atitude em relação ao câncer e a seu portador.

Algumas razões contribuíram para que as atitudes em relação ao câncer fossem mudadas. Como exemplos, podemos citar algumas cirurgias bem-sucedidas na extirpação de tumores, e consequente cura, 
e o fato de alguns pacientes famosos terem ido à mídia incentivar outros que estavam fechados em si mesmo, envergonhados por terem ficado doentes. Tudo isso acabou gerando o direito de dar ao paciente o seu diagnóstico, o que até então era negado, por ser considerado uma atitude cruel.

O estigma e os mitos que envolviam o câncer puderam ser substituídos por conhecimento e instrumentos de enfrentamento tais como os tratamentos, grupos de autoajuda, suporte psicossocial etc. A partir desses fatos foi possível explorar e estudar respostas e comportamentos psicológicos associados ao câncer.

Um dos grandes méritos da nova área consistiu em reunir diferentes profissionais promotores de saúde, emergentes das ciências médicas, criando aquilo que hoje conhecemos como Psico-Oncologia.

O movimento da Medicina Psicossomática e o consequente surgimento da Psiconeuroimunologia e da Interconsulta Psiquiátrica foram alavancas preciosas para o surgimento desse novo campo do saber.

No início do século 20, o desenvolvimento de técnicas cirúrgicas e das medicações anestésicas propiciaram algumas "curas" de câncer, mas sempre na dependência do tipo de tumor e da fase em que era descoberto. A cura dependeria de sua remoção com sucesso, e da ausência de metástases (Holland, 2002).

Radiação juntamente com cirurgia era o tratamento para o câncer, ao longo dos primeiros anos do século 20 .

Com a fundação do Memorial Sloan-Kettering Cancer Center, em 1880, tem início um trabalho que objetivava desenvolver estudos voltados para a descoberta de maneiras de lutar contra o câncer.

Atualmente grupos trabalham com o objetivo de desenvolver pesquisas, com a meta de obter cada vez mais conhecimento para transmitir à classe médica, aos pacientes e familiares, e ainda às equipes promotoras de saúde em geral. A proposta desses grupos permanece a mesma, ou seja, como lutar contra o câncer. 
Em seguida, em 1937, é criado o National Cancer Institute.

Segundo Holland (2002), a partir de 1948, relatos de remissões em câncer têm início, criando cada vez mais esperança em pacientes, familiares e equipes médicas.

Holland (2002) relata que as curas foram responsáveis pela diminuição do imenso pessimismo que cercava o diagnóstico de câncer, uma vez que aquilo que antes podia ser fatal passava a ser uma doença a ser enfrentada e não ocultada.

A partir desse momento, uma mudança na visão de equipes de saúde e familiares ocorre, no sentido de informar ao paciente o que se passava com ele, para que o próprio portador da moléstia pudesse ajudar em sua recuperação.

Essa mudança de comportamento vai criar o campo fértil onde se desenvolveriam as propostas de um diálogo aberto entre paciente e equipe, e os princípios que nortearam os protocolos de pesquisa em que os sujeitos eram devidamente informados daquilo que estava ocorrendo, e que daria posteriormente origem e definição às normas para a realização de pesquisas com seres humanos.

Foram iniciados movimentos para a criação de grupos de autoajuda, e ainda um programa que oferecia a um doente a visita de outro paciente que tivera o mesmo tipo de câncer e que fora curado, chamado "ex-paciente", no sentido de melhor informar ao portador sobre a doença, procedimentos e intervenções.

Esse programa teve muito sucesso, pois era a fala de um expaciente e não mais da equipe médica, levando o doente a acreditar em sua própria cura.

Em nosso modo de ver, esse era o início de uma proposta até hoje aceita com bastante restrição por diferentes classes de profissionais de saúde, proposta que inclui os aspectos emocionais nos processos de desenvolvimento de um câncer, bem como de sua remissão. 
Alguns mais ousados chegam a relatar correlações entre o estresse psicológico vivido por um indivíduo e o posterior surgimento de um câncer. Este estresse seria consequência de perdas, tanto de pessoas como de situações, aposentadorias indesejadas, mas obrigatórias, enfim, toda uma gama de situações dolorosas muitas vezes sequer percebidas pela pessoa.

A resistência à compreensão psicológica e sua importância para as doenças orgânicas é antiga. Vale lembrar que, na Idade Média, eram atribuídas ao portador de doenças mentais diferentes causas fantasiosas, sendo a mais conhecida a possessão demoníaca. A pessoa em geral era afastada do convívio comunitário, quando não era queimada em fogueiras purificadoras.

A contrapartida desse comportamento são o sanatório e os hospitais psiquiátricos, que isolam a pessoa da mesma maneira, tratando-a com intervenções que vêm sendo combatidas nos últimos anos, dentro de um processo de humanização que foi iniciado e que pretende atingir todo tipo de doente e os cuidados exigidos dentro e fora do hospital.

Diversos profissionais, especialmente os psiquiatras, lutaram incansavelmente para que o paciente fosse visto como um ser global, cujas mente e corpo existiriam como um continuum, e não separados um do outro e onde o organismo doente teria relação com outras instâncias, tais como a psicológica, por exemplo.

A criação daquilo que hoje conhecemos como interconsulta foi 0 resultado da atuação desses profissionais, que lutaram para que o paciente fosse examinado como um todo e não apenas como um organismo doente.

A disponibilidade para aceitar a comorbidade psiquiátrica deu uma nova visão aos médicos e estudantes, para comportamentos até então pouco claros para o paciente de câncer.

Se até então o portador de câncer era tratado por clínicos gerais e oncologistas, a consulta psiquiátrica revelou a necessidade de 
medicações relacionadas a sintomas de angústia, depressão, ansiedade, entre outros.

Em meados do século 20, ocorre a chegada de diversos psicanalistas nos Estados Unidos, e o impacto das teorias psicanalíticas na psiquiatria americana é significativo. Têm início as publicações de Dunbar e Alexander, e o desenvolvimento do movimento psicossomático lança novas luzes sobre as doenças em geral e sobre a doença mental em particular (Holland, 2002).

Nesse período diferentes publicações associam fatores emocionais ao surgimento e desenvolvimento do câncer.

Esses tipos de trabalho tinham algum interesse teórico para os profissionais de saúde mental, e eram publicados em jornais ligados à psicologia e psiquiatria. Mas, no dizer de Holland (2002), infortunadamente não foram escritos juntamente com oncologistas e cirurgiões, e acabaram sendo vistos como especulações sem maior interesse científico.

Posteriormente foram desenvolvidos métodos de pesquisa mais fidedignos no sentido de explorar a relação de uma possível interação entre o fisiológico e o psicológico nos processos do adoecer.

O movimento denominado Medicina Psicossomática vai dar origem a duas novas áreas de significativa importância para o surgimento da Psico-Oncologia.

A primeira delas tem início por volta das décadas de 60 e 70, quando são publicados os primeiros trabalhos de Ader e Cohen, reunidos em um texto denominado Psiconeuroimunologia (1981) em que os autores expunham de maneira cuidadosa os estudos que provavam a interação entre os sistemas neurológico, endócrino e imunológico.

Uma das descobertas da Psiconeuroimunologia diz respeito ao comportamento das NK cells, como dissemos anteriormente, células que têm a função de identificar e eliminar quaisquer células que pareçam diferentes, anômalas, em um organismo humano. Comprovou- 
se uma diminuição dessas células, no caso de alterações causadas por lesões do sistema nervoso central.

A descoberta mais importante relacionada a Psiconeuroimunologia, porém, diz respeito a estudos que implicam fatores psicossociais na predisposição do início e progresso de várias patologias, incluindo as neoplasias malignas (Ader, Cohen \& Felten, 1995).

As depressões clínicas, segundo estes autores, estão associadas a uma diminuição do número de NK cells e o consequente surgimento de tumores malignos.

Essa não foi a primeira vez em que estados emocionais foram correlacionados a processos tumorais como vimos nas referências a Galeno e a outros médicos da Antiguidade. Ainda não foi descoberto o elo que nos permitiria relacionar diretamente estados de estresse causados por experiências de vida ao surgimento de neoplasias, no entanto os estudos da Psiconeuroimunologia vêm sendo desenvolvidos no sentido de explorar essas relações, e suas implicações clínicas e terapêuticas.

Os estudos sobre o impacto do estresse bem como o tipo de enfrentamento utilizado pelo paciente sobre o sistema imunológico foram importantes ferramentas utilizadas para maior compreensão do surgimento e desenvolvimento do câncer.

No entanto, permanecem pouco claros os mecanismos do sistema imunológico em relação aos fatores de risco para o adoecimento de um indivíduo por câncer, bem como a sobrevida a essa doença por parte de alguns doentes. Mas com certeza é uma área independente que tem contribuído bastante para o desenvolvimento de pesquisas relacionadas à doença.

A segunda decorrência do movimento da Medicina Psicossomática foi a criação do que hoje chamamos de Interconsulta Psiquiátrica, que tem como objetivo estudar o comportamento e os discursos recorrentes em termos de queixas do portador de câncer. Essas queixas muitas 
vezes pertenciam mais ao campo da Psicologia e da Psiquiatria do que propriamente ao campo da Medicina.

Em geral, eram queixas relativas à ansiedade, depressão e angústia.

$\mathrm{Na}$ década de 50, vários estudos prospectivos começaram a examinar as respostas psicológicas de pacientes hospitalizados, criando a possibilidade de pesquisas colaborativas, entre médicos e profissionais de saúde em geral. Foi possível observar como os pacientes enfrentavam a doença em diferentes estágios da mesma, até o momento da morte.

As descobertas mostraram que os sentimentos de culpa e vergonha estavam presentes em todos os pacientes, além do medo da dor e da deformação.

Outro comportamento observado foi a mudança do padrão de comunicação dos portadores de câncer. Conforme a doença ia avançando, sua comunicação começava a ficar mais limitada, como se a progressão da doença fosse algo a não ser comentado (Holland, 2002).

\section{O Início Formal}

Em função de sua juventude, junto aos processos de luta contra o câncer, é possível traçar um histórico bastante fiel do surgimento da Psico-Oncologia, seu desenvolvimento e sua capacidade de penetração em diferentes partes do mundo, bem como as barreiras que enfrentou ao "desmoralizar" o estigma que sempre acompanhou o câncer, considerada uma doença incurável e que levaria à morte, inexoravelmente.

Se quisermos datar formalmente o início da Psico-Oncologia, podemos nos reportar às palavras de Holland (2002, p.213): "Beginnings of psycho onchology date to the mid-1970", em artigo publicado com a finalidade de divulgar o início de um movimento que passou a mudar as atitudes e os conceitos a respeito do câncer. 
Segundo a autora, é importante fazer uma breve revisão da história da Psico-Oncologia, pois para ela, essa subespecialidade da Oncologia produziu, há aproximadamente 40 anos, um modelo, na verdade do domínio da Psicologia, que integra diferentes áreas do conhecimento, tais como a Medicina, a Psicologia e a variada gama de procedimentos pertencente à área dos cuidados paliativos, inclusive o cuidado com o paciente fora de cuidados terapêuticos, ou terminal.

Fator importante a não ser esquecido foram as publicações de Elizabeth Kubler-Ross, na década de 60. Ela desafiou pacientes e médicos a parar de evitar a iminente aproximação da morte, propondo um diálogo franco e aberto sobre o tema. Chegou a denunciar o isolamento em que os pacientes permaneciam, a partir da aproximação da morte, sem que ninguém se dispusesse a ouvir o que tinham a dizer sobre isso.

Seus trabalhos marcaram o início do movimento denominado Thanatologia nos Estados Unidos, movimento que posteriormente se disseminou pelo mundo inteiro.

Apesar da afirmação de Holland (2002) de que a Psico-Oncologia criou um modelo de intervenção em relação aos pacientes portadores de câncer, em nosso modo de ver, não existe ainda um modelo de intervenção, uma vez que profissionais provenientes de diferentes áreas promotoras de saúde podem ser psico-oncologistas, o que por si caracteriza diferentes práticas em ação.

$\mathrm{Na}$ verdade, a Psico-Oncologia procura dar aos profissionais de saúde em geral, às famílias envolvidas e à comunidade como um todo uma nova visão sobre o câncer, uma possibilidade de compreensão do processo de adoecer, como consequência de fatores biopsicossociais, e propõe ainda a possibilidade de uma maior compreensão das respostas psicológicas ao adoecimento, aos tratamentos e, posteriormente, à reabilitação e à sobrevivência.

Antes dos movimentos citados anteriormente, a possibilidade de uma visão mais ampla em relação ao paciente portador de doenças com 
origem orgânica tem início, a partir do século 19, logo após as publicações de Freud denunciando aspectos psicológicos na etiologia da histeria, e posteriormente no início do século $20 \mathrm{com}$ a publicação da Interpretação dos Sonhos.

No caso do paciente portador de câncer, além de fatores emocionais presentes, podem ocorrer desordens psiquiátricas que frequentemente podem tornar mais difíceis as intervenções sobre a doença. As mais comuns são a ansiedade, a depressão e o delirium.

De acordo com Holland (2002) diferentes pesquisas vêm sendo feitas, no sentido de avaliar a frequência das depressões em câncer, além de outras relatando as respostas a intervenções psicofarmacológicas e psicossociais.

Segundo essa autora, a partir desses trabalhos foi possível iniciar alguns tipos de ensinamentos aos estudantes de medicina, especificamente os que se dedicam à oncologia, no sentido de colocálos a par dos resultados encontrados.

Atualmente já existe um currículo de Psico-Oncologia que é utilizado em cursos de especialização em diferentes partes do mundo. Esses cursos estão abertos a profissionais de diferentes áreas que desejam conhecer melhor o que seria a Psico-Oncologia, uma vez que em suas áreas de origem focalizam os aspectos psicológicos das doenças.

Diferentes movimentos levaram a diferentes tipos de pesquisa ao redor dos anos 70, buscando os aspectos psicossociais do câncer. 0 objetivo em geral era encontrar modelos teóricos que explicassem a forma de enfrentamento da doença, já que essa atitude estava diretamente relacionada aos processos de remissão.

Um dos movimentos mais importantes nesse aspecto foi o iniciado pela medicina comportamental, que criou diferentes protocolos com o objetivo de pesquisar a mudança de hábitos como fator importante na prevenção do câncer. Aliada à medicina comportamental estava a psicologia behaviorista, que utilizava as técnicas de condicionamento 
com o objetivo de levar a mudanças significativas na maneira de viver, mudanças estas que seriam preventivas em relação ao surgimento de um câncer.

Segundo Holland (2002), os psicólogos comportamentais deram à prevenção do câncer o impulso mais importante a partir de seus estudos de como mudar o estilo de vida para reduzir sensivelmente a incidência de um câncer.

O trabalho desses profissionais em relação ao tabagismo, tipo de dieta e exposição ao sol, além de exercícios físicos, foram fundamentais para a consciência da população em relação aos cuidados com sua própria saúde.

Uma das últimas adesões no cuidado do portador de câncer e suas famílias vem representada por religiosos, e é grande o número de pesquisas e escalas para avaliar o quanto a crença e a fé podem intervir no desenvolvimento da doença e sua eventual remissão. Esses instrumentos estão validados e disponíveis, sendo utilizados especialmente nos estudos sobre o enfrentamento do câncer, e vem gerando publicações importantes.

Em função de sua proposta multidisciplinar, a Psico-Oncologia não para de receber a adesão de diferentes profissionais e grupos. Holland (2002) lembra a importância das contribuições de enfermeiras e assistentes sociais, que foram das primeiras pessoas a identificar a complexidade das respostas psicológicas ao câncer, seu desenvolvimento e seus sintomas. Especificamente no controle da dor e no provimento de suporte social dos pacientes, essas profissionais tiveram papel importante no início da Psico-Oncologia.

$\mathrm{Na}$ verdade o que podemos observar é a atualidade da PsicoOncologia enquanto área que propicia a união de diferentes profissionais promotores de saúde, respondendo portanto a uma tendência mundial no sentido de formar profissionais que atuem em conjunto, contribuindo com suas diferentes visões para o enriquecimento do cuidado com os pacientes. 
No Brasil, um projeto proposto pelo Ministério da Saúde vem sendo estudado e aplicado de maneira experimental por algumas áreas ligadas à promoção de saúde, projeto este que tem o objetivo de formar profissionais para atuar na saúde pública, estagiando já nos primeiros anos de graduação junto a instituições da rede pública, para futuramente atuar junto ao Sistema Único de Saúde (SUS).

Experiências junto a familiares de portadores de câncer vêm sendo realizadas no sentido de encontrar modelos de intervenção em grupo, como por exemplo, o trabalho junto a casas de apoio para crianças aguardando Transplante de Medula Óssea (TMO) realizado por Campos, Álvares, Machado e Rodrigues (2007).

As autoras relatam intervenção em que, além dos psicólogos, a presença de psiquiatras e enfermagem foi importante para a realização da pesquisa.

$\mathrm{Na}$ verdade a proposta era entender por que mães de crianças encaminhadas para TMO não demonstravam mais interesse em cuidar dos próprios filhos, praticamente abandonando-os aos cuidados de outros moradores da casa de apoio onde estavam. Este trabalho está descrito de maneira mais completa mais adiante neste texto.

A partir de um grupo cujos encontros teriam a finalidade de falar das angústias em relação aos filhos e suas doenças, o que apareceu foi a tentativa de desligamento como uma estratégia para sofrer menos caso a criança viesse a falecer.

Pesquisas qualitativas de caráter interventivo vêm sendo utilizadas e são de grande auxílio no sentido de colher subsídios para a criação de serviços em hospitais, casas de apoio e mesmo em atendimentos de caráter particular. 


\section{A Psico-Oncologia no Brasil}

Diferentes caminhos levaram à constituição da Psico-Oncologia no Brasil.

Muitos profissionais psicólogos já trabalhavam atendendo pacientes portadores de câncer, sem, no entanto esse atendimento seguir uma abordagem específica denominada Psico-Oncologia.

$\mathrm{Na}$ verdade a Psico-Oncologia é uma área de conhecimento que não possui uma proposta teórica, mas sim busca um "Modelo Teórico de Intervenção", sempre com base no atendimento integral do paciente, seu familiar e as equipes de saúde.

Como citamos anteriormente para, alguns, essa área seria uma sub-área da Psicologia da Saúde, para outros é uma interface entre a Medicina e a Psicologia, para Holland (2002) é uma subespecialidade da Oncologia ou ainda uma sub-área da Psicologia.

No Brasil, a proposta de uma definição foi baseada nos conteúdos dos dois encontros realizados em 1989 e 1993, de acordo com Gimenes (1994, p.46):

A Psico-Oncologia representa a área de interface entre a Psicologia e a Oncologia e utiliza o conhecimento educacional, profissional e metodológico proveniente da Psicologia da Saúde para aplicá-lo:

10. Na Assistência ao paciente oncológico, à sua família e aos profissionais de Saúde envolvidos com a prevenção o tratamento a reabilitação e a fase terminal da doença;

20. Na pesquisa e no estudo de variáveis psicológicas e sociais relevantes para a compreensão da incidência da recuperação e do tempo de sobrevida após o diagnóstico de câncer;

30. Na organização de serviços oncológicos que visem ao atendimento integral do paciente (físico e psicológico) enfatizando de modo especial a formação $e$ o aprimoramento dos profissionais de Saúde envolvidos nas diferentes etapas do tratamento. 
Só por essas diferentes maneiras de contextualizar a PsicoOncologia podemos perceber que ainda estamos no momento de conceitualizar a Psico-Oncologia, de defini-la enquanto área temática, de caracterizá-la enquanto identidade do profissional que atende o portador de câncer.

Cabem as perguntas: "se o oncologista é Psico-Oncologista, o que o caracteriza como tal?"; "Se o psicólogo é Psico-Oncologista, qual seria sua especificidade para ter esse título?" E daí em diante, em relação a outros profissionais envolvidos no cuidado do paciente de câncer, tais como o fisioterapeuta, o fonoaudiólogo(a), o enfermeiro(a) entre outros.

Após quase 30 anos de sua criação, essas questões são um desafio que promovem uma permanente reflexão e discussão entre os profissionais de saúde que aderiram a esta área.

$\mathrm{Na}$ verdade, no Brasil, alguns autores que foram exaustivamente lidos e estudados, tais como Simonton, LeShan, Schavelson entre outros, já haviam estudado o câncer, e atendido pacientes, sem dar a esse tipo de atuação o nome de Psico-Oncologia.

Antes de Jimmie Holland e o grupo do Memorial Sloam Ketering Center passarem a utilizar esse termo, os estudos e atendimentos envolvendo o câncer foram se desenvolvendo e produzindo conhecimento sem necessariamente utilizar o termo Psico-Oncologia.

Atualmente, outros autores que escrevem sobre os processos de adoecimento por câncer, bem como o tratamento possível dos pacientes e familiares, passaram a utilizar a denominação Psico-Oncologia.

Na América Latina, Schavelzon (2004), em Buenos Aires, é um dos autores que utilizam essa denominação. Mas, atualmente, já existem autores e pesquisadores na Índia, Japão, Europa de modo geral, e Américas, que escrevem sobre o atendimento de pacientes com câncer, e como lidar com o desenvolvimento da doença, que são considerados autores da Psico-Oncologia. 
Mas foram Carl Simonton e Lawrence LeShan os primeiros autores americanos a pesquisar por que alguns pacientes de câncer morriam e outros tinham uma sobrevida aparentemente inexplicável, se tinham a mesma doença, no mesmo estágio, e contavam com o mesmo tratamento.

A partir de suas investigações, LeShan (1994) verificou semelhanças entre alguns comportamentos de pacientes portadores de câncer, tentando estabelecer um padrão de personalidade que explicaria a incidência da doença.

Concomitantemente ao trabalho de LeShan, Carl Simonton, observou padrões de comportamento semelhantes nos pacientes que sobreviviam apesar de um diagnóstico bastante pessimista, chegando a algumas conclusões que publicou e que tiveram bastante sucesso, mas que infelizmente não cumpriam com as exigências de uma pesquisa científica.

O fator que estaria correlacionado à sobrevida de pacientes condenados à morte pela doença seria a necessidade de se manterem vivos, pois existia alguém que dependia deles ou havia um fator motivacional pessoal, uma formatura, por exemplo.

LeShan (1994) relata casos de pacientes que, no momento em que não tinham mais a obrigação de serem provedores e cuidadores em relação a um dependente, vinham a falecer. Da mesma maneira que Carl Simonton, formulou hipóteses interessantes sobre o câncer e seus portadores, chegando este último a criar um programa de atendimento ao paciente descrito mais adiante, cujo embasamento teórico seria altamente criticado por outros profissionais, uma vez que não seguia os critérios exigidos por pesquisas de cunho científico.

$\mathrm{Na}$ verdade, na década de 70, Simonton, como oncologista e radioterapeuta que era, deu início a um tratamento psicoterápico com os pacientes, complementando as intervenções médicas às quais vinham se submetendo em função da doença. Observou que os pacientes que se submetiam a esses procedimentos tinham uma 
sobrevida bem maior, à medida que seguiam uma abordagem que envolvia corpo, mente e espírito. Foi pioneiro no atendimento em grupo a pacientes de câncer.

Esses autores foram os primeiros com os quais grupos de profissionais de saúde entraram em contato, iniciando um interesse pela área da oncologia, pacientes portadores de câncer e os problemas psicológicos que surgiam em consequência da doença, necessidade de adaptação à mesma.

Em São Paulo, influenciados pelos autores citados, o primeiro grupo que se propôs a estudar sistematicamente o atendimento global ao paciente de câncer começou a se reunir por volta do início da década de 80. Esse grupo foi batizado de Centro Alfa, por esta autora, e era coordenado pela psicóloga Profa. Dra. Maria Margarida de Carvalho, uma das pioneiras da Psico-Oncologia no Brasil.

A ideia inicial era estudar textos relacionados ao Programa Simonton, criado por Carl Simonton, e iniciar atendimentos a pacientes de câncer utilizando essa abordagem.

A proposta de Carl Simonton era apresentar aos pacientes reunidos em um grupo e sempre acompanhados por um familiar a relação entre mente e corpo, demonstrando a importância eventual desta relação no surgimento e no decorrer de um câncer. Os pacientes deviam encontrar-se ao longo de nove semanas no programa original, e em cada semana era proposta uma atividade e uma reflexão sobre um tema relacionado ao câncer, ao adoecer, aos tratamentos, sempre acompanhados por relaxamento inicial e uma visualização baseada nas ideias de Milton Erickson apresentadas em texto de Rosen (1994). Nas visualizações os pacientes visualizavam imagens propostas pelo coordenador do grupo, que faziam parte de um programa estruturado voltado para a auto ajuda e conhecimento sobre a doença.

Posteriormente um grupo de pacientes e ex-pacientes entrou em contato com o Centro Alfa, e desses contatos foi criado o CORA Centro Oncológico de Recuperação e Apoio. 
Em função de diferenças em relação a aspectos teóricos, alguns profissionais emergentes do grupo inicial deram origem a outro grupo, denominado Re-Vida, com proposta diferente em relação àquela oferecida pelo CORA, não utilizando o Programa Simonton em seus atendimentos, introduzindo, além das reuniões grupais, alguns exercícios e técnicas corporais fundamentadas pelas teorias de Reich.

Em 1987, coube ao CORA providenciar a tradução para o português do livro de Simonton (1978), Gettig Well Again que, no Brasil, recebeu o nome de "Com a vida de novo". O livro contém uma parte teórica sobre a interação mente-corpo, e um programa de exercícios denominado "Caminhos para a Saúde".

O livro foi estudado pelo grupo de profissionais, e foi iniciado um processo de atendimento a grupos de pacientes, coordenado pelos profissionais inicialmente reunidos para estudar todo o processo seguindo exatamente as diretrizes propostas pelo livro.

Na década de 80 , foi feito um convite à Dra. Magdalen Creighton, uma das diretoras do "Cancer Support and Education Center", da Califórnia, para que viesse ao Brasil, e ministrasse uma conferência no Instituto de Psicologia da Universidade de São Paulo, a qual teve grande repercussão para os interessados no trabalho com pacientes de câncer.

Meg Creighton, como era chamada, na época veio com uma equipe, para demonstrar como eram o procedimento e os atendimentos na clínica dos EUA, e esta autora se recorda do espanto ao ver que uma das conferencistas da equipe era uma ex-paciente de câncer.

Era estranho ver alguém que tivera câncer e não só estava ali viva, falando, como ainda trabalhava nos grupos da clínica que a tratara.

Esse impacto foi sentido por diversas pessoas que assistiram à conferência, pois era uma absoluta novidade em nossos meios, uma vez que estávamos em 1982, há 27 anos, portanto. 
Diferentes adaptações do $\mathrm{PAA}^{3}$ original foram feitas (Ribeiro, 1998), no sentido de adequar o programa à realidade brasileira. A autora relata o atendimento feito em hospital da rede pública na periferia de São Paulo, que deu origem a um grupo em atividade até os dias atuais, o Chronos I - Centro Humanístico de Recuperação em Oncologia e Saúde.

Sendo o Brasil um país com componentes culturais bastante diversos dos padrões americanos, e ainda diferentes entre si de acordo com cada região do país, era impossível utilizar os mesmos padrões utilizados nos EUA.

Atualmente diversos grupos trabalham com programas de Auto Ajuda, sem necessariamente seguir as linhas propostas pelo Programa Simonton original.

É importante registrar que Carl Simonton parou de publicar durante muitos anos, em função das críticas que recebeu por parte dos médicos, e da interpretação errônea que muitas pessoas deram ao seu método. Uma dessas interpretações era de que o paciente era responsável por ter ficado doente. Por mais absurda que possa parecer, o que alguns falavam era que da mesma maneira como haviam criado um câncer tinham condições de eliminá-lo.

Isso só gerava angústia e culpa nos pacientes, e fez com que Simonton se retirasse do cenário das publicações, e quem levou adiante o programa foram Magdalen Creignton e seu marido James Creighton.

Carl Simonton criou mais um centro de tratamento do câncer na Suíça e atualmente esse centro atende doentes portadores de câncer utilizando seu método.

Simonton faleceu em 3 de julho de 2009 aos 66 anos

\footnotetext{
${ }^{3}$ O nome "Programa de Auto Ajuda" foi uma denominação dada pelo CORA e é como o programa é conhecido no Brasil.
} 


\section{Possibilidades de Intervenção em Psico-Oncologia}

Mas a vida, a vida, a vida, a vida só é possivel reinventada.

Cecília Meireles

\section{Aspectos Gerais}

As intervenções em Psico-Oncologia não diferem, em seus objetivos, das intervenções psicológicas em geral, onde o objetivo é sempre o bem-estar do paciente.

Segundo Holland (1998), os primeiros profissionais ligados à promoção de saúde que começaram o processo de dar alguma assistência de caráter psicológico aos pacientes de câncer foram as enfermeiras e assistentes sociais.

Pela própria proximidade e convívio com os pacientes, essas profissionais perceberam a demanda por algum tipo de atendimento que auxiliasse nas reações emocionais em relação ao progresso da doença e aos tratamentos aos quais eram submetidos.

O que distingue o profissional de Psico-Oncologia é que, para prestar assistência a um paciente portador de câncer, seus familiares ou mesmo à equipe de saúde que atende esse tipo de paciente, esse profissional deve dominar alguns aspectos não exigidos necessariamente em outros tipos de atendimento.

A primeira exigência a ser cumprida diz respeito ao conhecimento em relação ao câncer e tratamentos relacionados à doença. Não é importante dominar o discurso do oncologista, mas sem dúvida é necessário um conhecimento básico da doença, suas modalidades e seus tratamentos. A razão dessa necessidade reside no fato de que, para cada tipo de câncer, suas características, sua localização e os tratamentos que exija, o paciente apresentará um tipo de reação. 
Mesmo que saibamos que essa reação ocorre, não podemos prever como reage cada pessoa. A mesma dependerá de algumas variáveis como, por exemplo, a idade do paciente, sua classe socioeconômica, sua estrutura psíquica, sua personalidade em relação a suportar frustrações e a enfrentar os eventos da vida, variáveis estas pré-existentes ao surgimento da doença.

Em relação aos tratamentos, mais importante ainda será o conhecimento do psicólogo, pois os efeitos colaterais são vários e podem gerar estados emocionais complexos. Uma interpretação inadequada desses estados pode ser prejudicial ao paciente.

Um dos principais aspectos aos quais devemos estar atentos é a depressão. Sabemos que um estado depressivo pode afetar o sistema imunológico do paciente, sendo, portanto, importante que esse sintoma seja detectado o mais precocemente possível para que o paciente possa ser medicado e o problema possa ser eventualmente atenuado ou eliminado.

No caso de atendimento a pacientes fora de cuidados terapêuticos, terminais, muitas vezes ocorrem situações tais como delirium, causado por algumas medicações, ou estados maniformes, que devem ser relatados ao médico responsável pelo paciente, ou ainda estados confusionais em que o paciente perde a noção de tempo e espaço.

A partir dessas reflexões, fica evidente a necessidade de uma formação específica para atendimento de pacientes portadores de câncer. O que não quer dizer que sem essa formação um profissional não possa desenvolver seu trabalho caso se depare com um paciente doente. Só o ato de acolher, ouvir e estar ao lado de uma pessoa doente já é reconfortante para ela. Porém, a cada dia, cresce a procura por cursos de formação em Psico-Oncologia, por profissionais que desejam se instrumentar melhor para assistir pacientes portadores de câncer. 
A partir da Portaria 3.535/98 do Ministério da Saúde, passou a ser obrigatória a presença de um profissional de psicologia em todas as clínicas ou instituições que atendam a pacientes de câncer. Embora essa lei não seja cumprida de modo geral, muitos profissionais foram pegos de surpresa, sendo obrigados a prestar atendimento a pacientes portadores de neoplasia.

Além dos aspectos relativos à técnica no atendimento a pacientes de câncer, pudemos observar em nossa clínica, ao longo dos 20 anos de exercício, alguns fatores intervenientes em relação à assistência em Psico-Oncologia. Talvez produto de uma contra-identificação projetiva, no geral os profissionais que trabalham com essa área são mais atingidos por quadros de estresse, que termina por afastá-los ainda que temporariamente do exercício profissional.

Outra situação comum é a ocorrência de pedidos de transferência do local de trabalho, para outro local onde não tenham que lidar com portadores de câncer, o que também gera problemas, uma vez que as equipes passam a ter que se re-estruturar constantemente.

O que permanece são as palavras de Kubler-Ross (1981) em seu texto Sobre a Morte e o Morrer, onde chama a atenção para o fato de que, além de tratar e observar o que ocorre com o paciente, é fundamental entender e tratar o que ocorre com seus cuidadores.

Uma das preocupações da Psico-Oncologia é o cuidado com os cuidadores. Por cuidador entendemos tanto 0 cuidador profissionalizado, pertencente a uma equipe de promoção de saúde, quanto o cuidador domiciliar, que pode ser um enfermeiro contratado, um familiar, um vizinho, enfim, quem estiver disponível e que o paciente aceite como aquele que vai cuidar dele.

Os problemas que atingem um cuidador serão tratados mais adiante no item relativo à Equipe Multidisciplinar.

Tanto a equipe quanto o cuidador individual passam por situações semelhantes de angústia, desamparo, frustração e impotência, sendo importante um olhar sobre suas necessidades e demandas. 


\section{Atendimento Ao Paciente}

Já no prefácio do seu "Psycho-Oncology", o primeiro livro publicado pela equipe do "Memorial Sloam-Kettering Cancer Center" de New York, Holland e Rowland (1990) chamam a atenção para o que podemos aprender com os "real experts" em câncer e como lidar com ele. Os "real experts", segundo a autora, são o próprio paciente e seus familiares.

Qualquer atendimento a um paciente portador de câncer tem que ser voltado para técnicas integrativas, reconstrutivas e de suporte. 0 paciente portador de câncer passa por uma perda de suas certezas, o que, segundo Grassi, Biancosino, Marmai, Rossi e Sabato (2007), leva a sentimentos de medo, ansiedade, tristezas e culpa. Após um diagnóstico de câncer, a pessoa passa a lidar com a perspectiva de sua morte, ainda que isso não venha a ocorrer necessariamente.

Em função de crenças, fantasias e falta de informação sobre o câncer, mesmo a equipe de profissionais de saúde passa a temer a possibilidade de um câncer, caso ocorra um caso em um parente próximo, por exemplo.

De acordo com trabalhos realizados pela Escola de Enfermagem da Universidade de São Paulo (Pimenta \& Koziume, 1993), as crenças mais comuns apresentadas pelos estudantes das áreas de saúde estariam relacionadas com aspectos místicos, em que a religião seria o suficiente para a cura total da moléstia. Ainda de acordo com esses autores, a crença mais grave é a de que o câncer seria a sentença de morte para quem apresenta a doença e nada mais poderia ser feito.

Em função de seu estado físico e de seu diagnóstico, o paciente portador de câncer encontra-se profundamente fragilizado e, no geral, essa fragilização causa uma regressão psicológica da qual o paciente sequer tem consciência.

Almanza-Muñoz e Holland (2000) propõem um intenso treinamento para aqueles que desejarem atender pacientes portadores 
de câncer, treinamento este que passaria por conhecimentos de enfermagem, nutrição, serviço social, entre outros. O que a autora pretende com essa proposta é que quanto mais informado sobre os diferentes aspectos que surgirão na relação com o paciente, mais instrumentalizado estará o psicoterapeuta. Sua afirmação principal é de que, em uma crise física, em uma doença visível e não imaginada, o foco da terapia tem que estar no "Aqui Agora".

Além dessa condição, ainda segundo a autora (Holland, 2000), o terapeuta deve sentir empatia pelo paciente, e avaliar a situação em termos contratransferenciais, ou seja, que emoções o paciente suscita nele, se tem condições de atendê-lo.

Por exemplo, profissionais que sofreram a perda de um ente querido por câncer muitas vezes não têm condições de atender um portador da doença por sofrerem muito com as lembranças que inevitavelmente vão experimentar.

Holland e Rowland (1990) afirmam que pessoas que passaram por um câncer e sobreviveram podem ter interesse em entender a dinâmica de suas personalidades e de sua história a partir de experiências pelas quais passaram. Nesse caso, se estão curados ou estão em um período de remissão longa, a abordagem psicanalítica pode ser bem recebida.

Essa demanda por um conhecimento mais profundo de seus mecanismos mentais não ocorre com o paciente no momento em que toma consciência da doença. Nesse caso a "urgência" é quem dita as ordens, em função da possibilidade de o paciente estar lidando com a própria finitude e vulnerabilidade.

O contrato e o setting no atendimento ao paciente de câncer sofrem algumas adaptações em função da situação. Se o terapeuta não possui alguma flexibilidade para aceitar essas condições, não poderá trabalhar nessa área.

Questões relativas ao tempo do tratamento, ao local das sessões, à eventual participação de um familiar, ao sigilo, terão que ser 
analisadas cuidadosamente, uma vez que ao longo das intervenções variáveis absolutamente imprevistas podem aparecer, fazendo com que - que foi inicialmente acordado tenha que mudar, mesmo temporariamente.

Em função desse quadro, seria importante se os que pretendem atender portadores de câncer passassem por um treinamento específico, em Psico-Oncologia, com supervisões frequentes, e principalmente com a observação do que ocorre na contratransferência, pois estamos lidando com a nossa finitude e morte, ao lidar com a finitude e morte dos pacientes.

Finalmente, Holland (1990) alerta para que os pacientes tenham cuidado com os terapeutas que dizem ao paciente que ele é responsável por sua doença e pode tê-la causado, ou ainda que a psicoterapia poderá curá-lo independentemente dos cuidados médicos. Infelizmente esse alerta tem razão de ser, em função de algumas distorções que ocorrem em relação ao enfrentamento da doença.

Talvez as remissões espontâneas que podem ocorrer, e que são estatisticamente demonstradas, sejam as responsáveis por esse outro tipo de "crença" em relação ao câncer.

\section{Atendimento à Família}

A importância das relações afetivas tem sido amplamente comprovada, em todas as doenças e especialmente no câncer. Qualquer tipo de doença afetará sempre a família como um todo e não apenas o membro que adoece.

A família pode ser entendida como um sistema, onde os diferentes componentes são afetados sempre que alguma coisa atingilo. Desta forma, se um membro é atingido por alguma doença, o sistema como um todo sofrerá o impacto.

É importante lembrar que muitas vezes a definição sociológica de família não é determinante no caso do paciente de câncer. Nesta, os 
laços sanguíneos são os que definem uma família, mas muitas vezes elementos não necessariamente unidos por consanguinidade a um paciente podem ter importante atuação, tanto no sentido negativo como positivo.

O ideal seria que se organizassem redes de apoio às famílias de portadores de câncer. Mas esse fato é praticamente anulado pela cidade grande, diferentemente do que ocorre nas comunidades menores.

Ao atender um paciente em estado terminal em uma pequena cidade no interior de um estado da região sul do Brasil, pudemos observar pessoalmente as atividades desenvolvidas pela cidade no sentido de prestar apoio à família que havia sido atingida pela doença.

Os moradores faziam verdadeiros plantões na casa do paciente, ajudando na limpeza, na cozinha, levando flores, ficando para conversar. Todos sabiam exatamente o estado do paciente, cuidavam das crianças e mantiveram a rede até o final, quando o paciente veio a falecer. Soubemos que posteriormente continuaram a visitar a viúva e as crianças durante muito tempo.

Sabemos da impossibilidade de um comportamento semelhante na cidade grande, mas já existem redes de voluntários que fazem alguma coisa semelhante ao descrito, levando um mínimo de conforto aos familiares abalados.

Ribeiro (1994) lembra que a família passa por diversas etapas quando um de seus membros é atingido pelo câncer. São elas: a Aguda, por ocasião do diagnóstico, quando o choque emocional imprevisto apresenta um estresse maior do que o observado nas fases posteriores, que são Crônica, quando os tratamentos já se iniciaram, o paciente já está sob cuidados médicos, já tem maiores informações sobre a doença que o acometeu, e, finalmente, a fase de Resolução. Esta fase pode ser a remissão da doença ou ainda a ocorrência da morte.

Campos (2005) levanta a questão da "Qualidade" de vida em lugar do "Tempo" de vida, como um dos aspectos que eventualmente o profissional da Psico-Oncologia tenha que refletir junto com o paciente 
no caso da eventualidade da morte iminente. Nesses casos, a família é parte importante das decisões a respeito da continuidade de tratamentos muitas vezes extremamente dolorosos, que podem promover muito desconforto no paciente e que a certa altura se tornam inócuos em relação à doença.

Muitas vezes o atendimento à família do portador de câncer se torna difícil em razão do lugar que o paciente ocupa na mesma. É diferente a reação e adaptação à doença se o familiar doente for um idoso, do que no caso de um pai de família que tem a função de provedor e que é bem mais jovem. A mesma comparação pode ser feita em relação a uma vovó idosa e uma mãe jovem e que ainda é importante no cuidado com os filhos.

$\mathrm{O}$ atendimento às famílias deve observar a mesma flexibilidade que propusemos para o atendimento individual. O número de sessões, as pessoas que estarão presentes, o local das sessões, se o paciente participará ou não, são aspectos que devem constar do contrato, para evitar situações ambíguas e prejudiciais.

Como vemos, é importante que o profissional tenha uma formação específica para atendimento psicoterápico familiar, além do atendimento em Psico-Oncologia. Novamente o referencial teórico é importante para o terapeuta, mas não existe nenhuma exigência pela escolha de um referencial em particular.

No caso do falecimento do paciente, recomenda-se que a família continue em atendimento para que possa ser ajudada na elaboração do luto.

O que se observa é que a estruturação da família antes da ocorrência da doença irá influenciar todo o seu comportamento ao longo da mesma. Famílias estruturadas manter-se-ão estruturadas mesmo no caso de morte do paciente. Famílias desestruturadas, portadoras de problemas em sua dinâmica ou com algum dos seus elementos, serão mais trabalhosas e apresentarão problemas proporcionais aos que já enfrentavam antes do advento da enfermidade. 
Em experiência com um grupo de mães com histórico de famílias mal constituídas e atravessando momentos de muito estresse, Campos, Rodrigues, Machado e Alvarez (2007) observaram que a simples tarefa de cuidar dos próprios filhos com leucemia, internados em casa de apoio era abandonada, criando problemas junto a outras moradoras nas mesmas condições. Ao surgir a necessidade de sair de suas casas, muitas vezes localizadas em locais distantes, a família, já pouco estruturada em função de diversos fatores, passava a apresentar comportamentos inadequados que dificultavam inclusive os tratamentos das crianças. A ameaça representada por uma doença grave que pode levar à morte e ainda o ambiente estranho no qual eram obrigadas a viver criaram as condições para a liberação de algumas emoções que posteriormente foram discutidas e melhor compreendidas no contexto do grupo por serem comuns a todos os participantes.

A doença é sempre uma ameaça à integridade do indivíduo em seus aspectos somáticos, emocionais e sociais, na medida em que muitas vezes não temos um controle sobre o seu surgimento $e$ desenvolvimento. É essa ameaça que se estende para a família, sendo, portanto, objeto de cuidados por parte daqueles que se preocupam com o cuidado do paciente de câncer. Não raro essa sensação de ameaça se estende à comunidade, que também deverá ser cuidada, sempre que for possível. Alguns programas educativos podem ser úteis, mas devem ser acompanhados por profissionais treinados para essa tarefa.

Vêm sendo desenvolvidos estudos no sentido do cuidado que deve ser prestado a cuidadores domiciliares, uma vez que muitas vezes estão submetidos às mesmas pressões que os próprios familiares. São investigações recentes, mas importantes, uma vez que mesmo não sendo ligados por consanguinidade aos pacientes, esses cuidadores desenvolvem laços afetivos para com os mesmos, sofrendo o mesmo tipo de estresse que os membros da família propriamente dita. É importante ressaltar que, além dos cuidados, no caso de cuidadores domiciliares, os mesmos devem ser esclarecidos e assistidos com 
frequência, uma vez que devem manipular medicação e muitas vezes alguns instrumentos de cuidado ao paciente.

\section{Atendimento em Grupo}

Para que se possa compreender melhor o funcionamento e os efeitos de qualquer grupo, é importante lembrar alguns mecanismos mentais do indivíduo no momento em que participa de um grupo ou em que vive uma experiência que chamaremos, apenas para efeito didático, "grupal".

Um grupo não é apenas um conjunto de pessoas. Para que esse conjunto possa ser chamado de grupo, é necessário um objetivo comum ou um elemento comum que os mantenha unidos. Indivíduos podem reunir-se, conversar, mantendo uma regularidade quanto a horário e local, e, mesmo assim, não serão considerados um grupo necessariamente. $O$ que distingue um grupo de outros agrupamentos de pessoas é o objetivo comum de um determinado número de indivíduos, objetivo esse que passa a nortear e a motivar seus encontros e modos de funcionamento. A Antropologia apresenta diversos trabalhos sobre o desenvolvimento e evolução do homo sapiens sapiens, em que o agrupamento surge como uma forma de comportamento comum em determinadas situações.

Eliade (1969) relata o momento possível em que o homem se reúne formando um grupo, momento este em que fenômenos atmosféricos sem explicação aparente poderiam surgir como uma ameaça, fazendo com que as hordas se unissem formando grupos. Nesse caso, o elemento de ligação e de motivação para a formação do grupo seria o medo do fenômeno desconhecido. Ao se sentirem ameaçadas as pessoas ficariam mais próximas, criando para si a sensação de proteção pela proximidade.

Os rituais da antiguidade seriam criados como forma de aplacar a ira de um deus desconhecido ou de uma força maior, que poderia se 
acalmar mediante danças, cantos e oferecimentos de sacrifícios. Então, a variável que teria possibilitado a formação do grupo seria externa ao mesmo. Esse é o caso das guerras, momento em que o país se une para enfrentar o inimigo comum.

Os grupos de autoajuda que aparecem como uma possibilidade de intervenção por parte dos psico-oncologistas seriam uma versão dos grupos da antiguidade. Os pacientes portadores de câncer e seus familiares sentem-se ameaçados por um perigo que não podem controlar totalmente, e partilhar os medos e angústias que sentem em função disso tem se mostrado altamente eficaz.

Importante lembrar que o grupo de autoajuda, embora se inicie com a coordenação de um profissional com formação em PsicoOncologia, pode evoluir para um tipo de grupo do qual apenas os pacientes e familiares tomam parte. O profissional pode ser dispensado ou participar apenas esporadicamente de alguns encontros. Esses grupos não têm os mesmos objetivos dos grupos de psicoterapia, mas em nossa observação temos constatado efeitos altamente terapêuticos em seus participantes.

A duração, o local e o número de sessões dos grupos de autoajuda fazem parte de um contrato inicial, acordado entre os participantes e o coordenador, pelo menos nas primeiras sessões. Posteriormente, como dissemos, a figura do coordenador pode ser dispensada, ficando o grupo autônomo para se encontrar e partilhar suas necessidades de acordo com a demanda dos participantes.

Todo grupo tem uma cultura própria, que não é a soma das culturas de cada indivíduo participante. A chamada "cultura do grupo" não obedece necessariamente a parâmetros de escolaridade, origem, faixa socioeconômica etc. É um fenômeno particular a cada grupo, caracterizando-o e personalizando-o.

Uma das expectativas em relação ao coordenador de grupos em geral é que ele possa perceber e compreender a cultura do grupo que coordena em determinado momento. Mas o que podemos observar é 
que o grupo funciona como um espaço continente para a angústia, o medo, o desconhecido, fazendo com que o paciente sinta-se parte de um todo, com os problemas semelhantes aos seus, que compreendem o seu discurso.

Campos (2000) relata mudanças significativas no comportamento de um paciente a partir de sua frequência a um grupo. Segundo a autora, é visível a sua melhora na forma de lidar com o sofrimento causado pelos tratamentos, seus planos para um futuro próximo podem surgir, levando-o a ter expectativas e motivação para viver.

Simonton, Simonton e Creigton (1987), criadores de um programa para ser desenvolvido no contexto grupal, colocam o desejo de viver como um dos fatores mais importantes nos prognósticos de câncer. Muitos casos de sobrevida inexplicáveis, segundo os autores, devem-se à motivação para viver, ou ainda à necessidade de manter-se vivo por alguma razão.

Importante ressaltar que as afirmativas desses autores são fruto de sua experiência como pesquisadores de pacientes portadores de câncer. Não existem comprovações científicas de que o desejo de manter-se vivo ou a ausência dele, nos casos de óbito, possam ser responsáveis por essas ocorrências.

Segundo o autor, a participação do paciente em seus tratamentos e nas decisões relacionadas a sua doença podem ser de grande auxílio em sua recuperação ou ainda no desenvolvimento da moléstia, quando houver essa possibilidade evidentemente.

As bases teóricas do chamado Programa Simonton estão assentadas nas correlações existentes entre os processos mente-corpo e saúde-doença.

Com o advento da Psiconeuroimunologia e a comprovação de que estados emocionais interferem com o sistema imunológico, como no caso das depressões, o nome de Carl Simonton foi lembrado em diversos momentos como exemplo, para demonstrar a importância das emoções no desenvolvimento das doenças. 
A proposta do programa é ajudar o paciente a discutir suas angústias e medos em processos grupais coordenados por um PsicoOncologista. Simonton (1987) propõe uma série de encontros, em que os pacientes devem levar um membro de sua família ou um amigo importante em sua vida. Nesses encontros, vão sendo discutidos os aspectos relativos à doença, às formas de enfrentamento, às variáveis estressoras que teriam tido influência no desencadeamento e desenvolvimento do câncer e principalmente vão sendo passadas para o paciente e familiares informações claras sobre sua doença e os tratamentos a que deverá se submeter. É ainda trabalhado o estado emocional do familiar e o seu relacionamento com o paciente.

Em seu livro texto Com a vida de novo, Simonton (1987) relata casos diagnosticados como incuráveis e com prognóstico bastante negativo, em que os pacientes puderam ter uma sobrevida inesperada e mais longa do que a possível de acordo com a medicina.

O Programa Simonton foi adaptado por Campos (1998) para utilização em hospital da periferia de São Paulo e vem sendo utilizado até o presente em um serviço de atendimento a mulheres portadoras de câncer de mama.

A adaptação foi necessária em função das condições socioeconômicas distintas existentes entre Brasil e E.U.A., mas os resultados obtidos foram gratificantes o suficiente para que o serviço iniciado em 1994 perdure até hoje não mais no hospital, mas em uma faculdade de Psicologia da mesma região.

Apesar do desenvolvimento dos estudos sobre enfrentamento nos últimos anos, muitos aspectos relacionados ao desenvolvimento e/ou remissão dos processos de câncer permanecem pouco explicados. Isso nos faz lembrar constantemente que estamos lidando com seres humanos, e embora a ciência possa prever fenômenos naturais atualmente controláveis, o fator humano permanece imprevisível em certos aspectos. Holland (2002) alerta frequentemente para a necessidade de clínicos, terapeutas e pesquisadores em geral 
trabalharem em conjunto, criando um intercâmbio de informações que só poderão ajudar no desenvolvimento das abordagens psicoterápicas junto ao paciente portador de câncer e no da Psico-Oncologia de maneira geral.

\section{O Atendimento à Equipe Multidisciplinar}

Se o discurso da multidisciplinaridade é o discurso da diferença, a questão que surge nesse tipo de atendimento se inscreve na questão da alteridade. Se falamos em categoria da diferença, imediatamente nos deparamos com o outro, o estrangeiro. Aquele que fala uma língua diferente da minha. É preciso não só ouvi-lo, mas ainda entendê-lo. Decodificar sua linguagem para poder iniciar um diálogo.

Os grupos humanos estão submetidos irremediavelmente a diversos sentimentos que nem sempre têm explicações racionais ou simpáticas. Freud (1986), em sua Psicologia das Massas e Análise do Ego discorre exaustivamente sobre o tema.

Parece que um entrave dos mais importantes para a constituição de equipes de qualquer ordem diz respeito aos sentimentos que surgem no grupo, tais como insegurança, competitividade, inveja, desejo de agradar, desejo de acertar etc. No caso das equipes de saúde, historicamente coube ao médico o lugar mais importante, pois a ele cabe a intervenção que pode salvar. Mesmo que isso nem sempre seja possível, é assim que o médico é visto. Ele é colocado pelo grupo social, e até mesmo pela equipe, nesse lugar. Certamente ele detém o saber em relação à doença e sua atuação adequada pode mesmo salvar vidas. Mas no cotidiano de uma equipe nem sempre é isso o que ocorre. As necessidades são várias e distintas, cada profissional é requisitado em determinado momento em função de uma determinada demanda. $\mathrm{O}$ status não é mais dependente do conhecimento e da formação do profissional, mas da demanda que existe em relação àquilo que cada profissional pode oferecer. Por exemplo, um paciente que necessita de 
uma intervenção fisioterapêutica no caso de um câncer de pulmão, como terapia complementar, precisará de um fisioterapeuta a seu lado. O médico, a enfermeira, o psicólogo nada poderão fazer se a necessidade é por uma sessão de fisioterapia.

Esse é um dos aspectos importantes no treinamento de equipes multidisciplinares. A aceitação dos limites, o reconhecimento da necessidade de diferentes profissionais, cada um respondendo por uma demanda específica. Como já dissemos, o discurso da multidisciplinaridade é o discurso da diferença, o atendimento à equipe de promoção de saúde se insere na categoria da alteridade. O "outro" que vamos atender terá necessariamente uma visão e uma fala diferente da nossa.

Vários entraves pré-existem na constituição de uma equipe multidisciplinar, que por si só trazem situações estressantes a todos os membros participantes do grupo. No caso de equipes que lidam com o sofrimento e o medo causados pelo câncer todos os fatores se agravam.

Em visita a um Hóspice na periferia de Barcelona, Espanha, fomos levados a uma sala agradável, com alguns tipos de lanches leves, muitas plantas, revistas, e poltronas confortáveis.

Os Hóspices são locais especiais organizados para receber pacientes terminais; eles oferecem todo o conforto para esses doentes e se ministram apenas tratamentos paliativos. Neles, é permitida a permanência de um parente, objetos pessoais e até animais como canários. O mais conhecido é o St. Christofer's, fundado pela criadora da proposta, Dame Cicely Saunders

Ao indagar sobre a finalidade da sala, a resposta dada pelo médico-guia é que aquele lugar era o local de repouso da equipe do Hóspice. A cada período de troca de plantão a equipe era obrigada a permanecer por algum tempo naquela sala, onde era proibido falar de qualquer assunto relacionado a doenças em geral e ao câncer em particular. 
Foi-nos explicado que, em função da alta incidência de burnout nas equipes cuidadoras dos pacientes, haviam criado esse espaço com o objetivo de diminuir tensões inevitáveis, criar um espaço para troca de experiências e ainda um suporte para os componentes das equipes de saúde que compunham o quadro da instituição.

Nem sempre uma equipe está ligada a um atendimento limite como é o caso de pacientes terminais. Mas, mesmo assim, o que se observa é um alto nível de estresse nas equipes que atendem pacientes oncológicos em geral.

Várias listas de estressores vêm sendo construídas por profissionais ligados aos cuidados com o cuidador. Dentre os causadores de estresse mais frequentes, podemos contar com a alta incidência de decisões que implicam manter uma medicação, uma intervenção perigosa, ou seja, muitas vezes essas situações têm a ver com vida e morte do paciente.

Além desse aspecto, temos a questão da alta tecnologia ligada aos tratamentos de câncer, o que gera tensão na enfermagem, que deve manipulá-los, e mesmo na equipe médica. Apesar de treinamentos constantes, o cuidado na manipulação de medicações e aparelhos é um fator gerador de estresse.

O alto índice de mortalidade é outro fator estressante nas equipes. Muitas instituições especializadas em atendimento a pacientes de câncer convivem com a incidência de óbitos constantes, o que gera sofrimento e dor nas equipes como um todo.

Além desses aspectos, existem as pressões particulares a cada indivíduo, como por exemplo, exigências internas, pessoais, não necessariamente vindas da instituição.

Em função dessas reflexões, é possível imaginar a importância da intervenção psicológica junto às equipes sendo cada vez mais frequentes os estudos sobre esse assunto. Diferentes abordagens são utilizadas, com diferentes referenciais teóricos. Em geral, o atendimento é realizado em grupo, onde os profissionais cuidadores são incentivados 
a discutir suas angústias, sob a coordenação de um Psico-Oncologista. Se necessário, uma pessoa que apresente distúrbios indicadores de alto nível de estresse pode ser atendida individualmente além do trabalho feito em grupo.

Uma técnica que muitas vezes é utilizada com sucesso é a Dramatização. Para tanto, o Psico-Oncologista deve ter conhecimentos e experiência sólida na direção de grupos de Psicodrama.

Não é recomendada a utilização de um grupo de caráter psicanalítico, onde a interpretação é a ferramenta utilizada. Em geral o nível de ansiedade que permeia o grupo impede que essa técnica seja bem-sucedida. Além desse aspecto, muitas vezes o grupo tem que ser "aberto", ou seja, os membros podem entrar e sair dele, de acordo com suas escalas de plantão, por exemplo.

Campos (2005) lembra que o profissional de saúde enfrenta um conjunto de angústias no seu cotidiano. Os pacientes estão vulneráveis pela doença, querem apoio, segurança e intervenções "perfeitas e eficazes", nas palavras do autor.

Lidar com o sofrimento implica muitas vezes lidar com sofrimentos pessoais. Ainda Campos (2005), ao estudar grupos de cuidadores, reafirma a impossibilidade de lidar com a dor sem, de alguma forma, se identificar com ela. Apenas como exemplo, como ficar incólume se atendemos uma criança com câncer e temos em casa um filho com câncer.

Num caso como este o terapeuta precisa estar atento a suas projeções, para não atuar e eventualmente vir a prejudicar o paciente.

Na verdade, em nossa experiência, o lidar com crianças traz um sofrimento maior à equipe, pela representação social que a criança tem em nossa cultura, pela impotência e fragilidade diante da doença.

Em seu trabalho, Campos (2005) nos remete à questão do conceito de suporte social construído nos domínios da Psicologia Social. Segundo esse autor, os seres humanos se organizam em redes ou relações interpessoais, constituindo famílias, grupos e comunidades. A 
complexidade dessas relações é maior quando a doença atinge um ou mais de seus membros.

O autor propõe uma síntese daquilo que se poderia denominar "suporte social" a partir da leitura de diversos autores: "suporte social é uma forma de relacionamento interpessoal, grupal ou comunitário que dá ao indivíduo um sentimento de proteção e apoio capaz de propiciar redução do estresse e bem-estar psicológico" (Campos, 2005, p. 46). Campos (2005) lembra que o profissional de saúde é chamado a intervir em situações que, por exemplo, implicam risco de vida, quando decisões devem ser tomadas rapidamente. E relata que a angústia nestes casos é extrema. A exigência vem da parte do paciente, que demanda um atendimento cuidadoso, da família, que espera sempre soluções imediatas, e do próprio cuidador, que gostaria de resolver situações muitas vezes impossíveis de resolver. O autor conclui que a esses eventos segue-se a impotência, a frustração e muitas vezes a depressão e a culpa. E afirma ainda que a experiência de compartilhar pode ser um paliativo para tanta angústia. Relembra que o holding winnicotiano remete a uma estrutura básica de comunicação, que não passa necessariamente pela verbalização, e que pode nivelar uma equipe em relação a seus sentimentos, colocando todos em contato com suas fragilidades mas gerando um tipo de força que vem da sensação de não estar só, de pertencer a um grupo que passa pelas mesmas necessidades, e que principalmente sabe acolher a demanda de cada um e de todos.

Segundo Campos (2005, p. 123),

"não havia mais médico, enfermeiro, hipertenso, nutricionista, paciente. Havia pessoas que se respeitavam, que se ouviam, que se preocupavam umas com as outras e que se apoiavam". 
Atualmente muitos hospitais reúnem as equipes para encontros sem tema específico, apenas para que partilhem o que estão vivendo, no sentido de gerar a sensação de que pertencem a um grupo, não estão sós, têm a quem recorrer.

A Psico-Oncologia tem especial interesse no atendimento com os cuidadores de modo geral, e suas intervenções incluem a participação de um profissional da área nas reuniões de equipe, quando se trata particularmente de equipe de cuidadores de portadores de câncer.

Pedrosa (2010) relata experiência com grupos realizada de acordo com a proposta de Ballint, que pode ser uma possibilidade de ajuda às equipes, uma vez que só o fato de estar em um grupo, discutindo aspectos profissionais de atuação, que na verdade remetem às suas próprias pessoas, gera uma sensação de inclusão, diminuindo a vivência de desamparo e solidão.

Em geral, qualquer tipo de grupo, desde que coordenado por um profissional com conhecimento de técnicas grupais, pode ser de grande ajuda no cuidado com os cuidadores.

Atualmente a preocupação com as equipes de cuidadores vem originando diferentes estudos e tipos de intervenção. Embora estejamos ainda distantes de um processo mais metódico e eficaz, é crescente a preocupação com o tema e a cada dia hospitais da rede pública ou particulares iniciam programas com esse objetivo.

\section{Psico-Oncologia e Pediatria}

Tumores malignos em crianças são relativamente raros. Em função desse fato, as pesquisas nos processos de câncer despertam sempre o interesse surgindo como um desafio para os onco-pediatras.

A população infantil acaba sendo responsável pelos avanços na terapia do câncer ao longo das últimas cinco décadas. Steinherz e Simone (1998) atribuem ao tratamento de crianças com câncer a maior 
contribuição na compreensão e progresso dos desenvolvimentos nas terapias utilizadas nos adultos.

Os tumores mais comuns em crianças são as leucemias, os linfomas, os tumores neurológicos e os sarcomas. Esses autores afirmam ainda não haver grande disparidade em relação aos aspectos raciais (Steinherz \& Simone, 1998).

Os adolescentes são mais susceptíveis aos tumores ósseos e de Hodgkin. Segundo os mesmos autores, os tumores atingem tanto o sexo masculino quanto o feminino, não havendo diferença significativa em relação ao sexo dos pacientes (Steinherz \& Simone, 1998).

Da mesma forma que nos adultos, a causa que vai gerar uma neoplasia permanece desconhecida. Aparentemente existiria uma interação entre aspectos ambientais, fatores genéticos e outros desconhecidos, o que torna bastante complexa a identificação de uma causa única.

Entre as causas mais comuns identificadas, estão a radiação, as drogas, as substâncias químicas e as viroses. O que varia é a especificidade de um determinado tumor de acordo com a localização geográfica.

De qualquer forma, o câncer infantil é altamente sensível aos tratamentos, gerando índices de cura que atingem até $80 \%$, de acordo com diferentes autores.

Ainda segundo Steinherz e Simone (1998), as diferenças comuns no câncer em crianças são relativas ao tipo de tecido, à sua origem embriônica e em relação aos fatores causadores da doença.

A causa provável do índice de cura elevado no câncer infantil pode ser porque os cânceres pediátricos respondam melhor a terapias intensas e pesadas. Essas terapias são melhor suportadas pelas crianças do que pelos adultos.

A possibilidade de um diagnóstico precoce, segundo os autores citados, está no fato de os pediatras terem em mente a possibilidade de um câncer, uma vez que muitos sintomas da doença podem ser 
confundidos com gripe, no caso das leucemias, ou de artrite reumatoide, no caso de câncer ósseo, para citar apenas dois exemplos mais comuns (Steinherz \& Simone, 1998).

A maior dificuldade encontrada pelos oncologistas infantis reside no fato de que muitas vezes a criança não consegue expressar exatamente o que sente, demonstrando apenas irritabilidade.Com raras exceções, nenhum câncer infantil pode ser considerado incurável, não importa o tipo.

Um aspecto importante a ser considerado em relação aos pacientes pediátricos é que o cuidado exigido por uma criança, em geral, envolve momentos profundamente dolorosos para o médico. Ele é obrigado a desempenhar diferentes papéis, seja de confidente da família, ou mesmo conselheiro matrimonial, ou ainda o suporte para todas as angústias que forem aparecendo ao longo do desenvolvimento da doença.

Além disso, ele precisa ser um excelente profissional que preencha as expectativas de toda a família, o que é extremamente difícil, uma vez que essas expectativas em geral extrapolam a realidade, e podem cair no terreno das fantasias geradas pelas angústias dos pais.

Como se não bastassem todas essas cargas, o pediatra oncologista ainda precisa administrar suas próprias angústias e ansiedades.

É importante não esquecer que a criança ou o adolescente portador de um câncer continuam a ter os problemas inerentes à sua idade, à sua personalidade e às dificuldades daí decorrentes. Muitas vezes, dependendo da faixa etária do paciente, o médico e os familiares podem decidir o que é possível informar ou não, a respeito da doença.

Permanece a premissa de não enganar o paciente, mas além de tudo é necessária uma dose de bom senso sempre exigida em qualquer caso, levando em conta que pessoas diferem entre si, não existindo uma norma única para o procedimento do profissional. 
O diagnóstico precoce continua sendo a forma mais eficaz de lutar contra o câncer, tanto no adulto como na criança, o que leva à reflexão do papel educador da Psico-Oncologia, que deve criar e promover campanhas que orientem a população em relação aos sintomas que podem identificar a doença, bem como esclarecendo esta mesma população em relação aos mitos que cercam o câncer. Isso pode ser um caminho para salvar muitas vidas.

\section{Ajudando a Partir - A intervenção mais difícil}

A morte introduz a grande ruptura entre o animal e o homem. Essa ruptura é ainda maior do que a introduzida pela descoberta da ferramenta, introduzida pelo homo faber, a do cérebro pelo homo sapiens, a da linguagem pelo homo loquax (Morin, 1970).

De acordo com esse autor, a espécie humana.

"é a única para a qual a morte está presente ao longo da vida, a única a acompanhar a morte com um ritual funerário, a única a crer na sobrevivência ou no renascimento dos mortos" (Morin, 1970, p. 13).

É sempre difícil dizer adeus. Para o paciente, para o cuidador, para a família.

Em geral, para pacientes que não estão em coma, ou sedados, a aproximação da morte ocorre de maneira natural, se estão sem dor e já na fase da aceitação de acordo com a proposta de Kubler-Ross (1981).

Essa autora, ao estudar em profundidade os pacientes próximos à morte, observou alguns padrões de comportamento e classificou-os por fases

A primeira seria a fase da Negação, em que o paciente, ao receber a notícia de uma doença grave que poderá levá-lo à morte, recusa-se a aceitar esta ideia, ignorando aparentemente a seriedade do seu estado. A segunda fase seria a da Raiva quando o paciente se 
revolta com seu diagnóstico e prognóstico, passando a agredir familiares e cuidadores. A terceira fase seria a da Negociação, quando são feitas todas as promessas e rituais místicos para tentar livrar-se dos fatos. Na quarta fase, a da Depressão, os pacientes caem em uma profunda depressão e tristeza, chegando a parar de se alimentar e mesmo de falar por algum tempo. Em seguida, vem a fase da Aceitação, quando finalmente o paciente reconhece que não há nada a fazer, e inicia suas despedidas, que podem ser feitas de maneira simbólica muitas vezes, ou mesmo sem palavras.

Depois disso, o paciente passa a falar menos, a dormir muito mais, algumas vezes em posição fetal, regredindo emocionalmente cada vez mais, silenciosamente aguardando o desfecho.

Esta última fase pode ser de grande serenidade para o paciente e para os que o acompanham. Kubler-Ross (1981) relata que alguns dos momentos mais ricos de sua vida ocorreram quando ficava sentada ao lado de um paciente, segurando sua mão em silêncio, em profunda comunhão e paz.

Ao morrer, o paciente perde seu corpo, seu mundo, seus entes queridos.

Segundo Callanan e Kelley, (1994) existem alguns sinais que as pessoas próximas à morte podem apresentar. Um sinal bastante comum é o olhar vago, que parece atravessar objetos e pessoas sem se fixar em nada, muitas vezes os familiares interpretam este tipo de olhar como um estado de desatenção àquilo que ocorre à volta do paciente.

Estados confusionais, respiração mais lenta e menos audível, sonolência constante, alheamento em relação ao que se passa ao seu redor. Todos esses são sinais que podem significar a proximidade da morte.

Muitas vezes o paciente que está morrendo não quer barulho, não quer muitas pessoas ao seu redor, em geral uma ou duas quando possível. 
Em geral, a tranquilidade da morte pode depender de um bom controle dos sintomas, tais como a dor, a agitação, ou mesmo a angústia.

Um aspecto importante para o profissional que cuida de pacientes terminais é saber que a linguagem, muitas vezes confusa, pode na verdade ser uma linguagem simbólica, que pode ser decodificada se o cuidador conhece alguns aspectos da história de vida do paciente.

Callanan e Kelley (1994) relatam situações em que a linguagem simbólica estava diretamente relacionada com a proximidade da morte. Uma paciente, em conversa com o marido repetia constantemente um refrão que dizia "está na hora de entrar na fila". Outro que foi marinheiro por toda sua vida murmurava "preciso achar o caminho e voltar pra casa".

Evidentemente essas são apenas hipóteses uma vez que não temos a possibilidade de confirmar com os pacientes o que realmente queriam dizer. No entanto, após muitas observações foi sendo possível traçar um mapa dos sintomas e comportamentos dos pacientes que estão morrendo.

Um dos aspectos mais comuns e frequentemente relatados por familiares que acompanham pacientes em estado terminal, é a visão de pessoas já falecidas, que "aparecem" e são interlocutores invisíveis dos pacientes, que se dirigem a eles como se estivessem presentes. Ainda não temos explicação para esse tipo de evento. Podem estar relacionados a aspectos neurológicos relativos à memória, ou ainda a estados confusionais propiciados pela medicação, ou pela própria doença.

Muitas são as ocorrências sem explicação quando tratamos e cuidamos de pacientes próximos à morte, no entanto, da mesma maneira, muitas são as ocorrências sem explicação que ocorrem em situações de análise, em que o inconsciente demonstra aspectos intrigantes ao se revelar em sonhos. 
Em El porvenir de uma ilusion, Freud (1996) mostra a necessidade cultural de imortalidade que acompanha todos os homens. Em diferentes culturas e religiões os rituais funerários aludem a uma "vida depois da morte", a um "renascimento".

Embora não tenha a representação mental da ideia de morte, a pulsão de morte é uma das forças mais presentes em nosso mundo interno ao longo da vida. Não necessariamente aparecerá com conotações relativas à morte, mas, por exemplo, nos aspectos autodestrutivos que um determinado comportamento apresenta. No boicote a situações que poderiam trazer sucesso e em outras circunstâncias que nos mostram a presença da pulsão de morte.

Klein (1991), ao longo de sua obra, nos lembra que a angústia de morte acompanha o ser humano desde o seu nascimento, sendo responsável pelos sentimentos de ansiedade que estão presentes no mundo interno de bebês. Essa angústia seria vivida como um aniquilamento, uma ameaça persecutória à própria vida, ameaça de desintegração, pois o bebê não tem a representação da morte.

Klein (1991) se refere a uma "ansiedade primordial" contra a qual o ego estaria em luta constante, e que seria uma ameaça que surge da pulsão de morte. Afirma "(...) eu assinalei que não concordo com a visão de Freud de que o inconsciente parece não conter coisa alguma que substancie o conceito de aniquilação da vida..." (p 271).

Já no adulto, os sentimentos mais comuns em relação à morte dizem respeito ao medo do desconhecido que é vivido como persecutório, por não saber ou não aceitar uma finitude inerente à condição humana.

Uma forma de lidar com essa angústia é projetada em sentimentos religiosos, que implicam o questionamento de uma vida após a morte que não pode ser comprovada.

A questão que se coloca é a perda total de si mesmo e de tudo que ama. 
Se não desinvestirem afetivamente seus objetos internos e externos, os pacientes não passam para a fase de aceitação proposta por Kubler-Ross (1981), e consequentemente para a morte.

Para acompanhar um paciente que está morrendo, é importante que o profissional tenha feito um treinamento específico para esta situação, passando por workshops voltados para esse tipo de atendimento. Em nossa experiência, é importante que o cuidador procure elaborar questões relativas ao final de sua própria vida; sem isso, dificilmente terá condições de cuidar de um paciente terminal.

Muitos estudantes acreditam que gostariam de trabalhar com esse grupo de pacientes, mas após os primeiros treinamentos ou estágios percebem que não têm condições para tal. É importante que percebam suas limitações, o que não diminui em nada seu desempenho profissional em outras áreas.

Como vimos, são muitas as possibilidades de intervenção para os profissionais que desejem se dedicar a Psico-Oncologia. O ideal é que o aluno pretendente a esse tipo de atuação possa fazer ume estágio nas diferentes clínicas, para que escolha com mais tranquilidade onde quer trabalhar.

A enfermagem, em geral, é o grupo que mais sofre nos hospitais, uma vez que nem sempre podem escolher onde vão trabalhar.

Uma das atividades mais gratificantes para os psico-oncologistas é oferecer grupos de apoio a esses cuidadores, criando um espaço onde possam expressar seus sentimentos e angústias, o que só ajudará no seu desempenho profissional.

No entanto, em nossa experiência, muitas vezes esse tipo de serviço é solicitado a nós da Psico-Oncologia, e quando definimos local, hora e data de início do trabalho poucas pessoas aparecem.

Em um encontro informal em que isso foi levantado, ficou evidente que em geral o suporte teria que ocorrer "no momento" em que acontece o episódio que gera o estresse. Por exemplo, uma enfermeira solicitou auxílio em função de uma ocorrência que teria 
angustiado toda a equipe e principalmente a ela. Foi marcada uma entrevista, mas a enfermeira que desejava o atendimento não compareceu. Ao ser indaga sobre sua ausência respondeu que teria que ter sido "na hora", que mais tarde ela deu "conta do recado".

Isto cria uma situação que dificulta o auxílio a este tipo de profissional. Infelizmente ainda não temos um plantão em todas as clínicas em tempo integral que possibilite um atendimento imediato. Mas temos notícia de muitos serviços que persistiram, na forma de plantões em determinados espaços de tempo, que terminaram por serem procurados pelos profissionais ligados à promoção de saúde, em particular os cuidadores de pacientes de câncer. 


\section{A Oficialização da Psico-Oncologia no Brasil}

O primeiro encontro oficialmente reconhecido de profissionais, com o objetivo de dar início a uma discussão sobre a Psico-Oncologia, ocorreu em Curitiba, no ano de 1989, contando com poucos participantes. Nesse encontro ficou definida a próxima cidade a abrigar e promover um 20 Encontro, que seria em Brasília, em 1992, onde teve início a discussão em torno da fundação de uma Sociedade Brasileira de Psico-Oncologia.

Os profissionais que faziam parte desses encontros eram em sua maioria psicólogos, contando com poucos médicos e profissionais de outras áreas promotoras de saúde.

A próxima cidade a hospedar o que seria o $3^{\circ}$ Encontro foi São Paulo, e já então ocorreu não mais um encontro, mas o I Congresso Brasileiro de Psico-Oncologia, no ano de 1994, reunindo aproximadamente 500 participantes de diferentes categorias profissionais, e ao final do qual foi fundada a Sociedade Brasileira de Psico-Oncologia-SBPO.

Em 1993, antes da realização do assim denominado I Congresso Brasileiro de Psico-Oncologia em São Paulo, foi criado um curso de Psico-Oncologia no Instituto Sedes Sapientiae com a finalidade de difundir a área no meio universitário e preparar para o $3^{\circ}$ encontro, que passou a ser o I Congresso.

Em 1994, a Editora Psy lançou o livro Introdução a Psiconcologia, reunindo diversos temas relacionados à área. Esse foi o $1^{\circ}$ livro sobre o assunto publicado no Brasil.

A partir daí, a cada dois anos ocorreram congressos de PsicoOncologia, abordando os mais diversos temas, e com a participação de palestrantes de todo o país, e com alguns convidados internacionais.

Pela programação dos congressos, foi se constituindo o que hoje é o corpo da Psico-Oncologia, e foi sendo caracterizada esta área do conhecimento como uma área temática, interface de diferentes outras, 
tendo em comum a promoção de saúde no sentido de possibilitar uma qualidade de vida melhor para os pacientes.

Em 1996, tivemos o Congresso em Salvador, onde foi decidido que os dois primeiros encontros seriam transformados em Congressos, e ainda que a grafia até então da palavra Psico-Oncologia, que era Psiconcologia, passasse ao formato adotado por Nova Iorque: PsicoOncologia. Em alguns países ainda encontramos a antiga grafia, mas a proposta é a mesma e no mundo todo continua sendo a de oferecer cada vez mais conhecimentos sobre o câncer, sobre o comportamento emocional do paciente, seus familiares, e equipes de saúde.

Nesse congresso, uma inovação merece ser lembrada, que foi um Curso sobre Oncologia para leigos, oferecido aos moradores da cidade, reunindo uma população ávida por conhecimentos sobre a moléstia, como identificá-la e como combatê-la. Como participante ativa de todos esses eventos, lembro-me de pescadores junto a estudantes e médicos, participando atentamente do curso, unidos por um mesmo propósito.

Essa ideia foi repetida em outros congressos e encontros, ficando provada a motivação da população por conhecimentos relacionados ao adoecer por câncer, diminuindo um pouco o tabu que cerca a palavra.

Após a participação conjunta em congressos de outros países da América Latina, os participantes das diferentes diretorias da Sociedade Brasileira de Psico-Oncologia reuniram-se com colegas latinoamericanos, criando a Sociedade Latino-Americana de Psico-Oncologia.

Hoje, após 15 anos de sua constituição no Brasil, a PsicoOncologia conta com diferentes serviços de atendimento a pacientes, espalhados pelo território nacional, bem como com uma produção de conhecimento bastante significativa, com teses de mestrado e doutorado sobre o tema da Psico-Oncologia.

Em 1998, foi lançado um novo livro sobre Psico-Oncologia, relatando a criação de diversos serviços de atendimento ao paciente portador de câncer, seus familiares e seus cuidadores. 
Em Salvador, na Bahia, foi criado o Grupo pela Vida, coordenado por um médico, que propôs um Programa nos moldes do Programa Simonton, com a introdução de novos módulos, dos quais podemos citar a dança, por exemplo, com a intenção de mostrar a importância de uma consciência corporal mais lúdica para o paciente.

Em Recife, Pernambuco, foi criado um grupo com diversas atividades, tanto no cuidado ao paciente como no preparo de profissionais para trabalharem na área.

Em Fortaleza, Ceará, o programa Cuidando do Cuidador se propôs a preparar os profissionais de saúde para o cuidado de pacientes portadores de câncer e seus familiares.

Importante citar que essa área foi ganhando o respeito de outras classes de profissionais, e, hoje, congressos tradicionalmente médicos abriram espaços para conferências e mesas-redondas sobre PsicoOncologia.

Foi criado um currículo para uniformizar o conteúdo programático dos cursos de Especialização em Psico-Oncologia, respeitando algumas diferenças e necessidades regionais em função de algumas características típicas de cada região.

- Introdução à Psico-Oncologia

- Aspectos Médicos do Câncer

- Prevenção Primária, Secundária e Terciária.

- Personalidade e Câncer

- Qualidade de vida

- Família do Paciente com Câncer

- Teorias e técnicas psicoterápicas aplicadas à Psico-Oncologia

- Dor: aspectos médicos e psicológicos

- Teorias e Técnicas de Enfrentamento

- Viver e Morrer com Dignidade

- Pesquisa em Psico-Oncologia

- Cuidados Paliativos 
- Luto

- Bioética

- Espiritualidade e Câncer

- Implantação de Serviços em Psico-Oncologia

Esse modelo de currículo foi apresentado a IPOS - International Psycho-Onchology Society - em 1998, por representantes brasileiros junto à Sociedade, sendo aprovado para utilização nos cursos de Especialização em Psico-Oncologia.

Kovács, Macieira e Carvalho (2008) propõem alguns temas que devem ser utilizados ao longo da formação do profissional de PsicoOncologia, a fim de fornecer subsídios para que ele possa atuar em programas tanto de prevenção como de atendimento ao portador de câncer e seu familiar (p. 545):

a) percepção do estigma que envolve o câncer;

b) significado da experiência pessoal relacionada ao câncer;

c) percepção das especificidades de cada doença e das características do paciente;

d) percepção e compreensão do mundo interno do outro;

e) habilidades de comunicação envolvendo a escuta atenta e o estímulo à expressão de conteúdos e sentimentos;

f) continência do sofrimento das pessoas sob seus cuidados dentro do contexto de sua atuação profissional;

g) reconhecimento dos limites de sua atuação profissional desenvolvendo recursos para lidar com as próprias frustrações;

h) reflexão sobre aspectos éticos;

i) sensibilidade e disponibilidade para lidar com dor, perdas e sofrimento, em vários momentos do processo da doença e particularmente quando da aproximação da morte;

j) elaboração de parâmetros de avaliação do sucesso da intervenção tendo em vista a qualidade de vida do paciente e de seus familiares 
A partir de 2006, foi criado o titulo "Certificação de Conhecimento em Psico-Oncologia" referenciando, portanto aqueles que realmente podem se intitular Psico-Oncologistas.

Embora contando com subsídios generosos para suas pesquisas, os profissionais que estudam o câncer não conseguiram diminuir a incidência da doença, e o índice de mortalidade aumenta a cada ano em todos os lugares.

Algumas teorias propostas por médicos e ex-pacientes que conseguiram se curar, discutem a ingestão de alimentos que seriam responsabilizados pelo possível desenvolvimento de tumores, como o açúcar, os cereais refinados, além de uma vida sedentária, e outros fatores considerados nocivos, além do fumo, um dos poucos a apresentarem uma relação direta entre o hábito de fumar e o surgimento da doença (Servan-Schreiber, 2008).

Alguns hospitais, particulares e/ou da rede pública, implantaram serviços de atendimento a pacientes portadores de câncer e suas famílias, dentre os quais podemos citar alguns, como exemplo: o Albert Einstein, em São Paulo, o PAM -17- Posto de Atendimento Médico, na periferia de São Paulo, o Aristidez Maltez, em Salvador, os serviços clínicos de Psico-Oncologia da Associação de Combate ao Câncer, de Goiás.

Em todos os grupos que foram criados sempre levou-se em conta uma parte teórica e outra prática, que implicavam dramatizações e dinâmicas de grupo, o que fazia com que os participantes experienciassem as situações, enriquecendo o processo.

Atualmente, contamos com vários grupos que atendem pacientes portadores de câncer e seus familiares, bem como com instituições que oferecem cursos de especialização. Estes devem ser aprovados pela Sociedade Brasileira de Psico-Oncologia antes de seu início, para que sejam reconhecidos pela mesma. 


\section{Psico-Oncologia na Universidade de São Paulo}

Mestre não é quem sempre ensina, Mas de repente quem aprende.

João Guimarães Rosa

\section{Criação das Disciplinas}

Ao tentar compreender as opções profissionais dos alunos dos últimos anos de graduação em Psicologia, podemos perceber na maioria uma grande ansiedade em relação à escolha de áreas, linhas de atuação, possibilidades de mercado etc.

Essas observações são resultado de conversas com os alunos em supervisão próximos à formatura, ao longo dos últimos 30 anos, no exercício de uma prática sempre preocupada com a formação dos profissionais de psicologia.

O que víamos na Universidade de São Paulo até alguns anos atrás era uma ausência de disciplinas relacionadas a práticas e intervenções junto a pacientes portadores de doenças físicas mas não de natureza mental especificamente, fosse em hospitais, instituições de saúde, ou ainda nos consultórios particulares.

Historicamente o psicólogo sempre esteve ligado à Psiquiatria, atuando junto ao psiquiatra em processos de doenças mentais.

Ribeiro (1991) discute as opções e escolhas profissionais de psicólogos, tentando identificar fatores presentes nessa escolha, fatores estes de caráter consciente e inconsciente.

Até então, o que se observava era uma escolha maciça pela prática da psicoterapia e em seu trabalho a autora conclui que essa opção era consequência de diferentes fatores, que iam de status à necessidade de sentir-se em um vínculo mais profundo com os pacientes, propiciado pelo processo psicoterápico. 
Levados por preocupações relativas à formação dos alunos da graduação, alguns professores do Instituto de Psicologia da Universidade de São Paulo iniciaram um movimento no sentido de oferecer disciplinas optativas relacionadas às áreas de saúde, com o objetivo de oferecer outras possibilidades aos graduandos, que, não descartando a possibilidade de atuação em saúde mental, propunham outras áreas em que era possível a intervenção psicológica.

Concomitantemente, a Psicologia Hospitalar, a Psico-Oncologia, os estudos sobre a morte na Tanatologia vinham ganhando espaço e despertando a atenção de psicólogos de todas as partes do mundo.

Como citado anteriormente, quando da realização do I Congresso de Psico-Oncologia, em abril de 1994, diversos encontros regionais voltados para a Psico-Oncologia já tinham acontecido, apresentando e divulgando a nova visão e propostas de intervenção sobre o câncer oferecidas por esta área.

Com o intuito de levar essa nova prática para o âmbito da Universidade de São Paulo, foi apresentada à Câmara de Pós-Graduação do Instituto de Psicologia da Universidade de São Paulo, especificamente no Programa de Pós-Graduação em Psicologia Clínica, uma disciplina denominada: "Introdução à Psico-Oncologia: possibilidades de intervenção junto ao paciente, à família e comunidade", que foi ministrada no período de 1994 a 2002.

Posteriormente, esse curso passou a fazer parte de uma nova disciplina que englobava as questões da Psicologia da Saúde e Hospitalar além da Psico-Oncologia. Essa nova disciplina, PSC - 5851 "Novas possibilidades de Intervenção para o Profissional de Saúde: A Psicologia da Saúde, a Psico-Oncologia, a Psicologia Hospitalar", teve início em 2003, sendo ministrada até hoje, com reformulações e atualizações cabíveis no programa de Pós-Graduação em Psicologia Clínica. 
Como resultado dessas atividades, selecionamos alguns trabalhos de Mestrado e Doutorado que foram realizados, e que mostram as diferentes possibilidades de produção de conhecimento a partir destas áreas.

1) Gritos e Sussurros: a interconsulta psicológica nas unidades de emergências médicas do Instituto Central do Hospital das Clínicas da FMUSP.

2) Um estudo sobre a opção do aluno de psicologia para trabalhar com pacientes oncológicos: fatores presentes quanto à escolha.

3) Câncer e o imaginário masculino: A expressão da Doença para o Homem.

4) Conhecimento e compreensão do transtorno de pânico pela classe médica: especialistas procurados com maior frequência pelos pacientes após as primeiras crises.

5) A Psicologia no sistema de saúde pública: diagnóstico e perspectiva.

6) Qualidade de vida em pacientes com dor crônica.

7) Em busca de uma psicopatologia diferenciada: um projeto coletivo de ensino-aprendizagem e reabilitação psicossocial.

Além das atividades ligadas à Pós-Graduação, a partir de 2006 até o presente, vem sendo oferecida uma optativa para os cursos de graduação do IPUSP denominada PSC-3931 - Psicologia da Saúde Abordagem Bio-Psicossocial: Psicossomática, Hospitalar, PsicoOncologia, na qual a Psico-Oncologia ocupa parte significativa do programa, oferecendo ao aluno de graduação a possibilidade de conhecer essa prática, passando a refletir sobre a mesma a partir de textos, análises de casos, além de iniciar atendimentos pontuais nas clínicas do Hospital Universitário, sob a supervisão dos docentes responsáveis.

A grande dificuldade observada em relação à prática da PsicoOncologia diz respeito à resistência do paciente em aceitar qualquer tipo de ajuda psicológica, fazendo com que a demanda inicial seja bastante baixa. O que pudemos perceber é que, a partir dos primeiros encontros, o paciente toma contato com os benefícios desse tipo de 
atendimento, frequentando as doze sessões sem faltar, e posteriormente fazendo o follow-up proposto que consiste em algumas reuniões realizadas, no início mensalmente, depois a cada dois meses; depois ficam em aberto e, quando o ex-participante desejar um contato, basta que ele ligue para o laboratório Chronos responsável pelos atendimentos e agende um encontro com os participantes do mesmo..

Outra barreira diz respeito à própria classe médica, que, até onde podemos perceber, faz poucas indicações para os serviços de PsicoOncologia existentes.

Isso não se aplica a todos os médicos e/ou oncologistas, mas certamente encontramos poucas clínicas de tratamento e instituições de saúde que contam com psicólogos em sua equipe.

A partir da própria relação médico-paciente, historicamente mais importante do que qualquer outro vínculo nas áreas da saúde, o paciente só procura a Psicologia quando isso é sugerido pelo profissional com o qual vem se tratando da doença. Na rede pública encontramos outras dificuldades, tais como a rotatividade da equipe médica, a pouca disponibilidade física - consequência da moléstia - as dificuldades de locomoção, a falta de dinheiro para condução, entre outras.

Em nossa experiência, um sucesso nessa área diz respeito a um hospital da periferia de São Paulo, onde o mastologista responsável pelas cirurgias decidiu montar um serviço de atendimento psicológico a pacientes portadoras de câncer de mama. Em função da boa relação entre as pacientes e o médico, pudemos montar uma equipe multidisciplinar que trabalhou no sentido de criar um atendimento grupal baseado no Programa Simonton, de ajuda a pacientes portadores de câncer que como foi citado anteriormente consiste em aproximadamente doze encontros, onde os participantes recebem informações sobre a doença, e partilham suas angustias e medos sempre orientados por um profissional de Psico-Oncologia. Esta atividade posteriormente deu origem a um serviço dentro do Hospital. 
Infelizmente, com as mudanças que ocorrem na rede pública, o serviço não foi adiante, durando apenas dois anos (Ribeiro, 1998).

Os objetivos das disciplinas oferecidas para a Pós-Graduação e para a Graduação contemplam propostas de atuação prática, mas também leitura de textos que levantem questões sobre o raciocínio clínico, os tipos de práticas possíveis em um hospital com um paciente portador de câncer, e ainda os aspectos filosóficos envolvidos nas questões relativas ao binômio saúde-doença.

Além disso, pacientes fora de cuidados terapêuticos são objeto de muitas discussões. Os princípios ditados pela Bioética e o direito à morte com dignidade embora sendo campo de estudo da área denominada Cuidados Paliativos também são levantados e objeto da reflexão dos alunos e professores responsáveis. .

Esse campo multidisciplinar defende a ideia de que é melhor "menos dias de vida, com mais qualidade", em lugar da luta travada por profissionais de saúde para que pacientes portadores de doenças graves e/ou degenerativas sobrevivam ainda que levando uma vida vegetativa, ou sofrendo fisicamente sem sentido.

É importante ressaltar que as faculdades de medicina vêm dando espaço para discussões relacionadas a essa atitude, convidando profissionais da Psico-Oncologia para ministrarem módulos que abordam o tema da morte em seus currículos.

Em nossa atuação junto ao Hospital Universitário da Universidade de São Paulo, diversas vezes fomos convidados a proferir palestras para os internos e residentes de medicina sobre as questões psicológicas que envolvem o câncer, e como lidar com a finitude, a morte, o luto antecipatório tanto dos pacientes como de seus familiares e equipes de profissionais.

Propostas pedagógicas desse tipo para os estudantes de Psicologia, envolvendo atendimentos de pacientes orgânicos, portadores de doenças graves ou não, em nossa opinião envolvem aspectos 
emocionais dos alunos, que devem ser trabalhados e elaborados pelos docentes responsáveis.

De acordo com Kovács (2002, p.206)

"A proposta pedagógica está ligada aos princípios da aprendizagem significativa. Segundo esta abordagem é difícil dissociar aspectos cognitivos e afetivos, levando-se em conta três alicerces: teoria, prática e desenvolvimento pessoal".

Essa autora propõe ainda que a formação do psicólogo deve ir além do simples acúmulo de informações e práticas, confrontando-o com seus próprios valores e levando-o a reformulações e elaborações muitas vezes custosas. Kovács (2002) lembra que um processo significativo de aprendizagem leva em conta a experiência e a busca de sentido para ações e atitudes.

Em nosso modo de ver, é muito difícil esperar que jovens de pouco mais de vinte anos sejam levados a pensar com tranquilidade, na possibilidade da morte, da dor e do sofrimento.

A escolha por essas disciplinas pressupõe um tipo de aluno com preocupações especiais, em geral causadas por experiências pessoais de contato com a morte e a doença, em familiares ou amigos.

No primeiro encontro de apresentação do programa, em geral quando é feita a pergunta sobre o "porquê" da escolha, inevitavelmente surge um relato de caráter mais pessoal, que é partilhado com o resto do grupo e com os professores.

É no espaço dedicado às supervisões que todas essas questões são discutidas e trabalhadas.

Kovács (2002) lembra que a supervisão é uma mescla de aprendizagem com aspectos terapêuticos, com o que concordamos. Mas é fundamental manter os limites no sentido de não transformar esse espaço em um espaço de psicoterapia de grupo. Para isso, o docente ou docentes responsáveis por esse tipo de atividade devem ter suficiente 
experiência para não serem traídos por sua própria subjetividade e contra-transferência.

É importante manter o enquadre pedagógico, mesmo face ao surgimento de fortes emoções e identificações dos alunos com as situações.

Um bom exemplo foi uma situação vivida por esta autora na qual uma aluna foi atender um paciente que havia sido escolhido aleatoriamente para o atendimento no leito. Quando nos reunimos para a supervisão, a emoção contida da aluna era evidente, o que levou a uma proposta imediata para que relatasse o que havia acontecido. Mesmo chorando, ela relatou que o paciente atendido tinha aproximadamente a idade de seu pai que havia falecido alguns meses antes em consequência de um câncer de próstata, mesmo diagnóstico do paciente. Após partilhar 0 atendimento com o resto do grupo, a aluna relatou que sua emoção era por perceber que conversar com o pai ao longo da doença havia sido fundamental para o momento em que conversou com o paciente durante 0 atendimento. Ao final da supervisão, fez um depoimento sobre a utilização adequada das experiências de vida no exercício da profissão. Relatou que sabia que havia se emocionado por tudo ser muito recente, mas que junto ao paciente havia conseguido se conter e ouvi-lo, esclarecendo algumas dúvidas do mesmo em função de sua vivência com o pai.

Um dos aspectos mais enfatizados no ensino da Psico-Oncologia é a questão das crenças que envolvem o câncer. As pessoas em geral acreditam que o diagnóstico de câncer é significado de morte, e receiam se aproximar de tudo que lembre a doença, como se com isso pudessem impedir que ela venha a ocorrer. Esse é um comportamento típico daquele que ocorre em relação a qualquer tabu, quando nomear o objeto do tabu pode fazer com que ele se materialize. É fundamental lembrar que, ao trabalhar com câncer, estamos trabalhando com dor, morte, mutilações, mas também com curas e alívio de sofrimentos a partir de informação e de escuta acolhedora e empática. 
É importante informar os alunos sobre o que é o câncer, sua etiologia, os fatores predisponentes e os tratamentos existentes. Sem isso, não é possível atender portadores da doença, uma vez que muitos sintomas são exclusivamente decorrência de reações às intervenções medicamentosas. Saber diferenciar aspectos orgânicos dos emocionais é importante, mas, de acordo com a Psico-Oncologia, as reações psicológicas à doença e seus tratamentos é que devem ser objetos de pesquisa e atenção por parte dos psico-oncologistas.

Em função do interesse despertado por disciplinas relacionadas a atendimentos psicológicos de pacientes orgânicos e portadores de câncer, é nossa intenção aumentar sua duração para dois semestres: o primeiro seria dedicado aos aspectos teóricos abordados, e o segundo exclusivamente dedicado aos atendimentos supervisionados.

Ainda na Universidade de São Paulo, no Departamento de Psicologia Clínica do Instituto de Psicologia, foram ministrados alguns cursos de especialização nessa área. No momento não há nenhum sendo oferecido, mas é nossa intenção retomá-los a curto prazo.

Atualmente existem disciplinas que ensinam Psico-Oncologia em diversas faculdades de Psicologia, nos cursos de graduação. Existem ainda cursos de especialização na área, em outros estados além de São Paulo. Em São Paulo, o Hospital a.C. Camargo tem dois cursos; um de aprimoramento e um de especialização em Psico-Oncologia.

Em contato com os criadores da Psico-Oncologia, psiquiatras do Memorial Sloam-Kettering Center de Nova York, fomos informados de que é sua intenção iniciar o oferecimento de alguns workshops no Brasil, e em outros países, com o objetivo de divulgar a Psico-Oncologia como área de intervenção e pesquisa. 


\section{O Laboratório Chronos - A História De Um Serviço}

Após o início das disciplinas oferecidas aos cursos de PósGraduação supracitados, cada vez foi se tornando mais evidente a necessidade de dar continuidade aos estudos da Psico-Oncologia, e iniciar um serviço de assistência ao portador de câncer e seus familiares que pudesse ser oferecido à comunidade.

Em função das diretrizes que fundamentam a criação de laboratórios na Universidade de São Paulo, a realização de pesquisas e consequente publicação das mesmas era um tópico indispensável.

Em 1999, após o término do ano letivo, alguns alunos da disciplina oferecida no programa de pós-graduação, mostraram o desejo de dar continuidade a seus estudos e projetos, bem como o de prestar assistência aos pacientes de câncer.

No início do ano 2000, foi proposto o projeto de criação do Laboratório CHRONOS, que seria um centro de recuperação em oncologia e saúde, daí seu nome, além da alusão ao deus grego, uma vez que o tempo é variável importante para os pacientes portadores da doença.

O projeto foi apresentado ao Departamento de Psicologia Clínica uma vez que o laboratório ficaria ligado ao mesmo.

Em reunião do Conselho do Departamento de Psicologia Clínica foi aprovada a criação do Laboratório CHRONOS - Centro Humanístico de Recuperação em Oncologia e Saúde. 


\section{Os objetivos do laboratório:}

I - Promover estudos e pesquisas voltados à produção do conhecimento em suas diversas formas de prática clínica.

II - Incentivar a pesquisa das diferentes possibilidades clínicas, da Psico-Oncologia, não só em relação ao paciente portador de câncer como a seus familiares, e em consonância com o seu desenvolvimento científico, articulando-a com os estudos de outras áreas ligadas da produção de saúde não só física, como mental.

III - Promover cursos, conferências, seminários, treinamentos e reuniões científicas.

IV - Coordenar e promover publicações científicas de livros e revistas, além de manuais informativos, explicativos voltados à prevenção do adoecer em geral e especificamente no caso das neoplasias. As atividades contidas neste parágrafo relacionam-se à promoção da saúde psíquica de pacientes portadores de câncer, seus familiares e cuidadores, ligados às diferentes áreas de saúde e a outros tipos de serviços de caráter psicossocial em âmbito nacional ou internacional, inclusive através de convênios, acordos e colaborações com outras pessoas ou entidades de direito público ou privado, sendo vedada qualquer atividade de caráter político ou religioso. 


\section{Os membros do Laboratório:}

I - Participam do CHRONOS profissionais de nível universitário, alunos da graduação e da pós-graduação do IPUSP, estagiários, voluntários e outros que tenham suas propostas de atividades clínicas, de estudo e de pesquisa aceitas pela coordenação do laboratório;

II - Pessoal administrativo e técnico contratado para prestar serviços ao Laboratório através da Fundação Universidade de São Paulo com recursos auferidos através das atividades do Laboratório.

\section{Serviços prestados pelo Laboratório CHRONOS}

- plantão telefônico no local, com escala montada em horários específicos para esclarecimentos sobre o funcionamento do serviço e para agendamentos de triagens com atendimento momentâneo ou com horário marcado;

- entrevistas iniciais com características de triagem, uma vez que alguns pacientes precisam de encaminhamento a curto prazo;

- grupos de espera para os pacientes cujos procedimentos (cirurgia, quimioterapia, radioterapia etc.) não sejam de realização imediata;

- grupo semanal aberto aos pacientes, familiares e à comunidade, sendo de caráter informativo, propiciando a troca de experiências e buscando facilitar a compreensão e a aceitação da nova realidade desse paciente, ou seja, limitações e cuidados (esses grupos estarão abertos a pacientes oncológicos e/ou familiares que tenham ou não participado da entrevista inicial e serão coordenados por pelo menos dois participantes do serviço);

- serão fornecidos, em qualquer etapa do atendimento, esclarecimentos e orientações a pacientes e/ou familiares sobre a 
doença, tratamento, efeitos colaterais e possíveis sequelas, com o intuito de diminuir a ansiedade;

- atendimento psicoterápico individual e/ou grupal tanto a pacientes como a familiares;

- atendimento domiciliar ou no hospital em que o paciente esteja internado quando necessário;

- treinamento para profissionais da área interessados em conhecer as formas de atendimento do CHRONOS;

- atendimentos de caráter especial, realizado pelos docentes responsáveis pelo laboratório;

Posteriormente à sua fundação, foi criada a possibilidade de oferecer participação no laboratório aos alunos da graduação do curso de Psicologia. Essa participação limita-se a projetos de Iniciação Científica e participação nas reuniões de estudo e supervisão oferecida aos participantes já graduados. A entrada no laboratório não é restrita a alunos da USP, ficando aberta a todos que se interessem pela PsicoOncologia.

Foi criado, pelos membros do Laboratório (Anexo I), um Manual de Procedimentos, que é discutido com os participantes que estão iniciando suas atividades para que saibam dos procedimentos, obrigações, compromissos, enfim de toda a parte organizacional do Laboratório.

Todo ano é aberta a possibilidade de ingresso, com uma seleção através de entrevistas e "Role Playing".

O prazo obrigatório de permanência no laboratório é de um ano, e um Termo de Compromisso é assinado e renovado quando necessário.

Um dos primeiros projetos do Laboratório foi um vídeo didático, sobre o que vem a ser a Psico-Oncologia (anexo II) e que foi desenvolvido pelos participantes e distribuído em outras instituições fora da Universidade, para divulgação dos serviços prestados. 
Além do vídeo, o laboratório possui folders, e um site, que é alimentado e atualizado periodicamente, onde, além das informações básicas necessárias para um contato, são publicados trabalhos dos participantes, pesquisas que possam interessar à população que o visita e programação de eventos ligados à Psico-Oncologia.

Um dos objetivos a curto prazo do Laboratório é iniciar Grupos de Apoio a pacientes portadores de câncer nos moldes do Programa Simonton, ajuda a pacientes portadores de câncer, junto à clínica de Ginecologia e Obstetrícia do Hospital Universitário da Universidade de São Paulo.

\section{a) Atuação junto ao Hospital Universitário da USP}

A partir de sua criação, o laboratório deu início às suas atividades, estendendo sua atuação a algumas instituições de saúde, onde os participantes prestavam serviços, sempre na condição de colaboradores voluntários.

Além de alguns hospitais particulares, foi feito um convênio com a Casa Hope, casa de apoio a crianças portadoras de câncer, que ficam hospedadas na casa durante todo o tratamento, sempre acompanhadas pela mãe ou outro familiar.

Nessa instituição foram desenvolvidos alguns projetos de pesquisa com os acompanhantes (Campos, Rodrigues, Machado \& Alvarez 2007) criando subsídios para os tipos de intervenção posteriores.

Junto ao Hospital Universitário foi oferecido o atendimento ao paciente portador de câncer, e a partir de encaminhamentos feitos pela instituição foi-se estabelecendo um vínculo fortalecido posteriormente pela extensão dos serviços a pacientes internados portadores de outros tipos de doenças.

No momento em que foi feito um convite pela Superintendência do Hospital Universitário à coordenadora do Laboratório Chronos, para que pudesse haver um intercâmbio entre o Laboratório e o Hospital, 
criando a possibilidade de atendimento aos pacientes portadores de câncer, foi oferecido ao Hospital Universitário, por participantes do Chronos, o atendimento aos pacientes internados, sempre sob supervisão da coordenação.

A partir de convite da Superintendência, os doutorandos e mestrandos passaram a atuar junto às clínicas do hospital, participando ativamente das suas atividades, em reuniões de equipe, reuniões de pais na Pediatria, no atendimento a cuidadores no Programa de Assistência Domiciliar, na realização de grupos com a enfermagem de algumas clínicas.

A partir do ano 2000, foi constituído o Serviço de Psiquiatria e Psicologia Hospitalar do Hospital Universitário, o $\mathrm{Pq} / \mathrm{PH} / \mathrm{HU}$, passando o Laboratório Chronos a atuar juntamente com os psiquiatras do serviço, nos moldes de interconsulta e participação nos grupos realizados nas diferentes clínicas.

Em função da atividade dos participantes do Chronos junto ao Hospital Universitário, foi possível mostrar a importância de atendimentos de caráter psicológico junto à população que transita pelo hospital. Tanto os pacientes quanto os funcionários profissionais de saúde e administrativos foram sendo beneficiados pela atuação dos psicólogos.

Acreditamos que esse foi um fator importante na criação de uma Divisão de Psicologia dentro do Hospital Universitário, processo em andamento, mas já aprovado pelo Conselho Deliberativo do Hospital, com um coordenador pertencente ao quadro dos docentes do Instituto de Psicologia da Universidade de São Paulo, indicado sempre pela congregação do Instituto, com periodicidade de 2 anos.

Além da criação da Divisão, foi feito um projeto denominado Acadêmico Assistencial, em que docentes do Instituto de Psicologia ligados de alguma forma às áreas de promoção de saúde passaram a ter acesso ao H.U., podendo oferecer estágios aos alunos sempre sob sua supervisão. 
Esse projeto é aberto, permitindo que novos docentes que passem a ministrar disciplinas que exijam estágio nas dependências do hospital possam oferecer a seus alunos possibilidades de atuação junto ao Hospital Universitário. 


\section{b) Atendimentos realizados pelo Laboratório Chronos no Hospital Universitário}

A partir de agosto de 2003, o Laboratório Chronos iniciou suas atividades junto ao Hospital Universitário, e, apenas em um ano, os atendimentos de caráter psicológico passaram a ter um lugar significativo nos relatórios dos atendimentos e serviços prestados pelo Hospital a seus usuários.

No gráfico abaixo, constam apenas os números de atendimentos a pacientes internados, e aos participantes do Programa de Assistência Domiciliar. Não constam do gráfico os atendimentos pontuais realizados com profissionais de saúde que atuam no hospital.

Hoje, além dos atendimentos aos pacientes, o Laboratório é solicitado para palestras junto aos residentes, ou ainda para realizar grupos com a enfermagem de algumas das clínicas.

No ano de 2009 foram realizados grupos com as enfermeiras da Pediatria, a pedido das mesmas, oferecidos como um espaço para uma reflexão sobre sua atuação profissional, suas angústias e dúvidas.

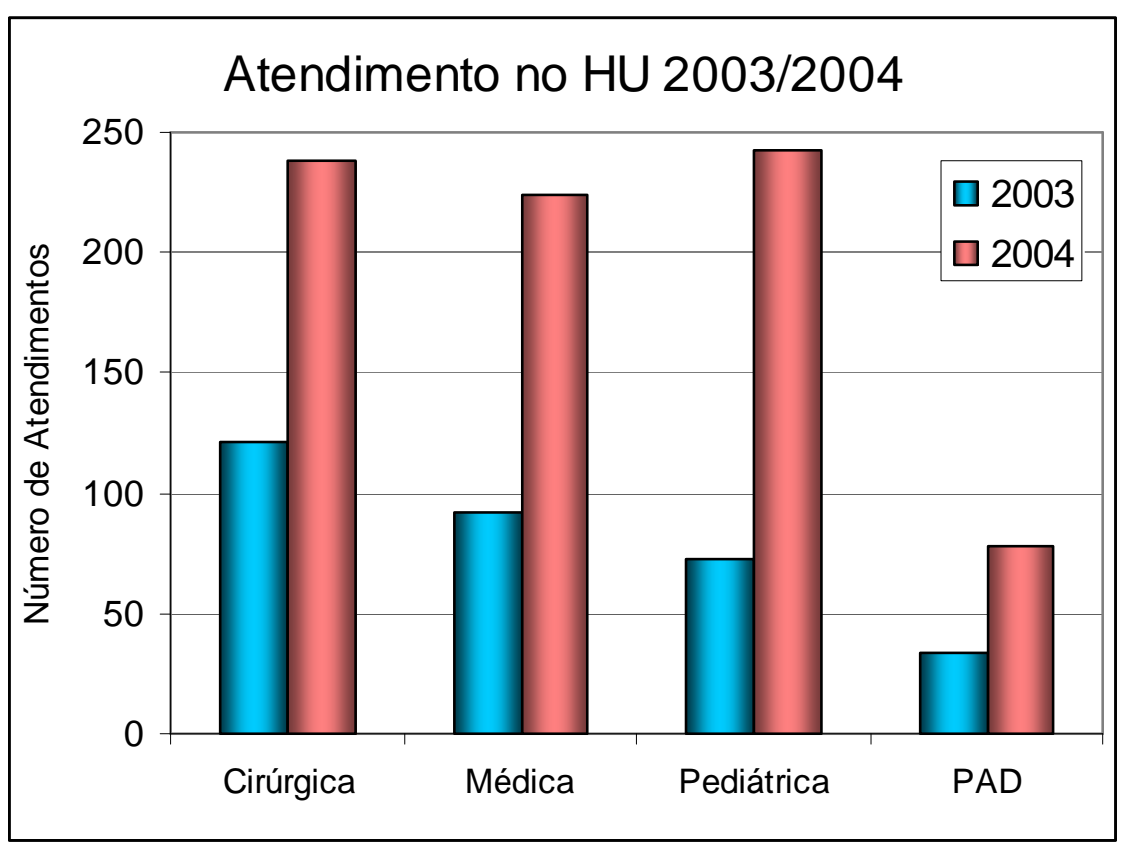


Obs.: Levando-se em consideração atendimentos ao paciente, ao familiar e ao grupo, os números representam valor aproximado

\begin{tabular}{|lc|}
\hline $\begin{array}{l}\text { Total de } \\
\text { Março de }\end{array}$ & $\begin{array}{c}\text { atendimentos } \\
\text { - Janeiro de } \mathbf{2 0 0 5}\end{array}$ \\
\hline Clínica & Atendimentos \\
\hline Médica & 222 \\
Cirúrgica & 235 \\
Pediátrica & 240 \\
PAD & 48 \\
\hline \hline Total & $\mathbf{7 4 5}$ \\
\hline
\end{tabular}

Esses foram os primeiros números a partir do início das atuações do Chronos no H.U. Atualmente, com novos participantes do Laboratório, o número de atendimentos cresceu, constando dos relatórios anuais do Hospital.

O Laboratório Chronos foi pioneiro no que diz respeito à criação de um serviço de atendimento a pacientes com câncer e seus familiares. Atualmente outras faculdades possuem serviços dessa natureza, muitas vezes inspirando-se na atividade do Chronos.

A partir das apresentações em congressos nacionais e internacionais dos trabalhos realizados pelos membros participantes do Laboratório, o mesmo é conhecido em diferentes estados do Brasil, servindo de referências muitas vezes para a criação de serviços de Psico-Oncologia, sendo um dos objetivos dessa área.

É nossa intenção, com o término dos trâmites para a instalação definitiva da Divisão de Psicologia, iniciar intervenções nos ambulatórios, bem como fazer pesquisas e oferecer estágio supervisionado para alunos dos cursos do Instituto de Psicologia interessados na Psicologia Hospitalar e na Psico-Oncologia. 


\section{A PRODUÇÃO DE CONHECIMENTO EM PSICO-ONCOLOGIA}

Há os pianos. Há a música. Ambos são absolutamente reais. Ambos são absolutamente diferentes. Os pianos moram no mundo das quantidades. Deles se diz "Como são bem feitos!" A música mora no mundo das qualidades. Dela se diz: "Como é bela!"

Rubem Alves

Como em todas as áreas que se propõem a pensar sobre sua práxis e seu desenvolvimento no âmbito das ciências, a Psico-Oncologia tem realizado pesquisas e publicado seus resultados desde a sua criação por volta de 1970.

Para Holland (2002), a Psico-Oncologia é uma subespecialidade da Oncologia; no Brasil, Gimenes (1994) propõe que "a Psico-Oncologia é uma área de interface entre a Psicologia e a Oncologia", o que nos remete à visão de uma área ligada à Psicologia da Saúde em última instância.

Falamos aqui de uma Psicologia da Saúde como a vertente que tem origem nos Estados Unidos, a partir da Medicina Comportamental, cuja proposta era a mudança de hábitos considerados nocivos à saúde, para outros comportamentos que levariam os indivíduos a novos comportamentos mais saudáveis, e ainda criando a noção de responsabilidade na promoção da sua própria saúde.

Segundo Gimenes (1994), a Psicologia da Saúde desenvolve-se a partir de conceitos psicológicos e amplia os limites da intervenção clínica onde a atuação na Saúde vai requerer uma intervenção mais abrangente, "na qual o trabalho com o paciente é apenas um dos aspectos relevantes" (p.47).

De acordo com essa autora, cria-se a necessidade do desenvolvimento de uma metodologia de pesquisa e estratégias de intervenção que "atendam em profundidade questões relacionadas à promoção, preservação ou à recuperação da saúde". Ainda, o termo 
Saúde "é utilizado no lugar de Medicina, que em geral está associada com processos de doença" (Gimenes, 1994, p.47).

Esse fato faz com que a Psico-Oncologia inicialmente lance mão de uma metodologia de caráter quantitativo, reconhecidamente aceita nas áreas médicas, no entanto, com o passar do tempo e a partir do seu desenvolvimento em diferentes países além dos Estados Unidos, a Psico-Oncologia passa também a produzir pesquisas de caráter qualitativo utilizando especialmente as práticas discursivas como instrumento de investigação.

O estudo das doenças, sua etiologia e epidemiologia sempre foram preocupação constante da humanidade, e mais ainda para os profissionais ligados à saúde.

Com o advento da psicologia e com a inserção dos psicólogos nas áreas da saúde, essa preocupação estende-se aos aspectos emocionais que envolvem as doenças. No caso do câncer, as reações psicológicas atingem não só os pacientes como seus familiares e equipes de cuidadores.

No entanto, em função de uma herança já quase extinta felizmente, os aspectos assistenciais acabaram se sobrepondo à produção de conhecimento durante algum tempo. Holland (2002) nunca deixou de alertar para a necessidade de um desenvolvimento paralelo, no que diz respeito aos aspectos do exercício da clínica e da produção de conhecimento.

Produzir conhecimento em Psico-Oncologia implica uma revisão na metodologia de pesquisa, uma vez que estaremos lidando com o significado da doença, da dor, da morte, tanto para o paciente quanto para o familiar, o profissional de saúde e a própria comunidade.

Como garantir um status de cientificidade a essa área? Com que paradigma devemos trabalhar nas nossas investigações que sirva a uma ciência biológica como a Medicina, e a uma ciência também ligada à Biologia, como a Psicologia, mas que tem sua origem na Filosofia e interfaces com as Ciências Sociais? 
Ao longo da história do desenvolvimento das ciências, existiram crises que resultaram em um salto qualitativo na produção do conhecimento científico.

Segundo Guba (1990), um paradigma científico é sempre um conjunto de crenças e valores que orientam a ação, e pode ser definido de acordo com as respostas que podem fornecer ao investigador tanto do ponto de vista ontológico, quanto epistemológico e metodológico na aceitação de uma verdade. Esse autor propõe um diálogo de paradigmas, uma vez que parte do pressuposto de que uma crise paradigmática atinge a contemporaneidade, e se propõe a oferecer as opções possíveis para a investigação científica, a partir daquilo que denomina "sucessores do positivismo convencional".

A questão da natureza científica de uma nova área de conhecimento é sempre objeto de reflexões e posicionamentos por parte daqueles que a exercem.

Qual o paradigma a ser utilizado para melhor pesquisar em PsicoOncologia?

Qual é exatamente o objeto da nova área? Com que instrumentos podemos investigá-lo? Enfim, muitas questões podem permanecer sem resposta por algum tempo ou para sempre.

Se nos voltamos, ainda que rapidamente, para a história do pensamento científico no Ocidente, vemos que dos fragmentos encontrados, os pré-socráticos como Anaxágoras, Anaxímenes, Heráclito, criaram hipóteses a respeito da constituição da matéria, da natureza, que seriam na verdade as precursoras das teorias da Física Moderna.

O Tempo e o Movimento já se constituíam em objeto de indagação dos primeiros filósofos. Mas nossa questão é: O que levou realmente os pré-socráticos a indagar a Natureza, a questionar a origem do espaço que os cercava, o céu, a terra, os fenômenos Naturais, enfim? 
Sabemos que a origem do pensamento filosófico reside na possibilidade do ócio - eschola, em grego - da classe dominante grega que Ihes permitia tempo para pensar e discutir longamente as questões que os inquietavam.

Assim nasceu a Filosofia.

Segundo Koyre (1991), a dissolução da ideia de Cosmo e a geometrização do espaço, que tem como consequência a matematização da ciência, marca o início do que se chamou Pensamento Moderno.

Conceitos hoje aparentemente simples de serem compreendidos escondem uma verdadeira revolução pela qual passaram os fundadores do que hoje chamamos de ciência moderna.

É difícil entender a passagem do pensamento do senso comum que implica um ponto de vista natural e observável, para outro que não é nada natural, onde se faz necessária uma linguagem numérica (a matemática) que o expresse. Por exemplo, uma linha reta passa a ser "y $=a+b x "$.

Da física de Aristóteles até a derrota de seu argumento por Galileu, o pensamento científico ocidental deu um salto que talvez não possamos avaliar.

Galileu nos ensina a interrogar a Natureza, formulando hipóteses que serão respondidas positivamente ou não. Para Galileu, a ciência passa a ser uma prova experimental.

Esse tipo de ideal científico, fundado na lógica matemática, tornase global, permitindo à epistemologia moderna criar critérios de demarcação entre as ciências.

Toda essa reflexão serve para as ciências da natureza, e exatas. Mas o que dizer em relação às ciências sociais e humanas?

A partir do séc. XIX, com o advento das ciências humanas, está instalada o que se chamou "Crise Paradigmática", que leva a uma rediscussão do que é realmente "científico". 
Ou seja, a separação entre ciências da natureza e exatas e ciências sociais e humanas passa a não ter sentido, em nosso modo de ver. Tudo deve ser rediscutido e repensado.

O observador e o sujeito podem interagir, sem o distanciamento até então exigido dentro de um referencial positivista.

Na verdade, o pensamento científico atual propõe que, para cada área do conhecimento, podemos utilizar o sistema paradigmático que mais respostas possa nos dar, mas sempre lembrando que a realidade só pode ser vista a partir de um sistema de crenças e valores, substrato de um grupo e de um tempo histórico e socialmente constituído.

Até o séc. XIX o Positivismo foi o paradigma utilizado para qualquer investigação que se pretendesse científica.

Só merecia o status de ciência o fenômeno que pudesse ser observado e medido e regido pela lei da causalidade científica. Com isso, pretendia-se um controle da natureza que garantiria segurança ao homem.

A constituição das ciências vai exigir a eleição de um objeto observável, bem como a criação de instrumentos que possam investigálo, mensurando-o e transformando o resultado dessas investigações em equações matemáticas universais. Com isso, um experimento poderia ser replicado por diferentes estudiosos em diferentes regiões da terra.

Ainda no séc. XIX, com o advento da Psicanálise e a proposta de Freud de transformá-la em ciência, surgiram questões epistemológicas em relação ao positivismo reinante na produção de conhecimento daquele momento.

Concomitantemente, a Psicossomática se constitui como uma proposta de maior entendimento do binômio saúde x doença, em que processos inconscientes poderiam interferir em aspectos somáticos, iniciando uma nova maneira de lidar com algumas enfermidades.

Surge a necessidade de melhor compreender um sintoma, além da frequência com que surgia em uma comunidade. 
As pesquisas quantitativas lentamente foram sendo complementadas ou até substituídas por pesquisas qualitativas, mais competentes na função de compreensão do paciente.

As investigações na área da Saúde, de quem a Psico-Oncologia pode ser considerada uma sub-área, passam a lançar mão de métodos qualitativos em suas pesquisas, além dos métodos quantitativos tradicionalmente utilizados até então.

Esse movimento não é unanimidade entre pesquisadores dos meios acadêmicos, muitas vezes encontrando resistências que se manifestam pela afirmação de que pesquisa qualitativa não tem o status de cientificidade necessária para ser utilizada na academia.

Spink (2003, p. 12) nos diz: "É o interesse pelos processos de produção de conhecimento que dá unidade às rupturas teóricas da minha trajetória..."

$\mathrm{Na}$ verdade, a proposta da pesquisa qualitativa não deixa de ser uma ruptura em relação àquilo que tradicionalmente se determinou denominar de científico.

Como aceitar um estudo de caso como representante de um determinado segmento humano, em lugar da "amostra" da pesquisa quantitativa?

Ainda segundo Spink (2003, p.30):

a psicologia ao contrário de outras disciplinas mencionadas tem aplicação prática nas áreas de saúde, e a emergência da psicologia da saúde, como campo de saber, está intimamente relacionada com as transformações que vem ocorrendo a partir da inserção do psicólogo na saúde.

No momento em que um novo campo do saber tenta se constituir como tal, é necessário repensar teorias e práticas. É isso que a PsicoOncologia vem propondo aos profissionais ligados à saúde que se especializam nessa área. Não basta apenas relatar práticas, mas 
também há que se construir modelos teóricos explicativos e compreensivos, que orientarão a práxis.

No início da atuação dos psicólogos na saúde, faltava o embasamento teórico-prático necessário para a compreensão dessa nova forma de atuação que fugia aos parâmetros da atuação tradicional desses profissionais (Spink, 1992).

Foi o momento em que se tentou levar o modelo do atendimento individual da clínica privada para o Hospital e o Posto de Saúde. Esse tipo de modelo de intervenção e de filosofia felizmente vem sendo substituído por práticas mais adequadas a uma psicologia comunitária.

A Psico-Oncologia surge na década de 70, quando a inserção do psicólogo no hospital geral era ainda muito recente. A descoberta de uma identidade profissional para atuar nessas áreas fazia com que muitas práticas fossem imitadas, em geral sob a hegemonia do saber médico, o que impedia um desenvolvimento teórico e prático genuíno. Essa situação vem se transformando nos últimos anos, e atualmente podemos contar com uma produção de conhecimento significativa na área da saúde em geral, e da Psico-Oncologia em particular.

Em função das reações emocionais desencadeadas por um câncer, tanto no paciente como nos familiares e equipes, surge a necessidade de um método de investigação que nos possibilite uma compreensão maior dessas reações. Mas, quando falamos de aspectos emocionais, devemos levar em conta questões relativas à subjetividade do paciente e o fato de que as reações podem sofrer variações decorrentes das características da personalidade de cada um.

Turato (2003) relata que autores como Flanders Dunbar, em seu Psychosomataic Diagnoasis, de 1943, propuseram que cada doença estaria associada a pessoas com um certo perfil emocional, desenvolvido em função de experiências vividas na infância. Essa autora descreve correlações entre uma doença e determinado tipo de personalidade a partir de questionários e testes psicológicos, o que, segundo o autor, mereceu críticas de Alexander (1989), criador do 
Instituto de Psicanálise de Chicago e expoente do movimento denominado Medicina Psicossomática.

Segundo Alexander (1989), os padrões de personalidade variam tanto entre pacientes com uma mesma doença, que no máximo se poderia falar de frequências mais ou menos significativas e não de natureza causal como pretendia Dunbar.

Turato (2003) alerta para o perigo de satisfação intelectual com correlações segundo ele, de alguma forma simplistas, como as $\mathrm{s}$ apresentadas nos exemplos de Alexander, como, por exemplo, aquelas relativas à origem de estados de raiva e de medo como responsáveis por elevações de pressão sanguínea e secreção gástrica acelerada, que estariam relacionados com impulsos reprimidos inconscientes.

No caso específico de um câncer, alguns autores investigaram uma possível correlação entre aspectos da personalidade e a ocorrência da doença.

LeShan (1994) agrupa alguns comportamentos que se repetiam nas suas investigações realizadas com pacientes portadores de câncer na busca de um padrão:

"Ao examinarmos os testes de personalidade de pessoas que posteriormente morreram de câncer, encontramos se melhanças surpreendentes na configuração de suas características e na história de suas vidas." (p. 23).

Na verdade, embora minucioso, o estudo de LeShan não pode ser considerado como uma lei científica, uma relação de causa-efeito, em função de diferentes variáveis que não foram controladas, como, por exemplo, o fato de todos os pacientes já estarem com câncer ao realizarem os testes e fazerem o relato de suas vidas.

LeShan (1994) pretendeu provar que existia uma configuração de personalidade comum a todos os pacientes mas essa configuração "comum" que apareceu poderia estar relacionada ao fato de todos eles 
já estarem doentes há algum tempo ao serem estudados pelo pesquisador.

O foco daqueles que se decidem pela investigação científica é atingir a verdade; seja utilizando pesquisas qualitativas ou quantitativas, o investigador está voltado para o estudo do fenômeno, tanto para compreendê-lo e explicá-lo como para controlá-lo e decifrar o significado que o mesmo tem para os que o vivenciam.

No caso da Psico-Oncologia, os estudos sobre as reações emocionais ao desenvolvimento da doença e seus tratamentos objetivam a compreensão desses fatos bem como as repercussões no paciente, uma vez que essas repercussões podem ter um papel importante no enfrentamento adequado de cada etapa do processo muitas vezes até sua resolução, que pode ser uma remissão duradoura ou a morte.

Segundo Denzim e Lincoln (p. 509, citado por Turato, 2005), "Os pesquisadores qualitativistas estudam as coisas em seu 'setting' natural, tentando dar sentido ou interpretar fenômenos nos termos das significações que as pessoas trazem para estes."

A palavra processo, que aparece constantemente nas citações que fazem referência ao método qualitativo, nos lembra que o mesmo se propõe a entender "como" ocorre o fenômeno, como ele se manifesta.

Turato (2005) lembra ainda que o método qualitativo se propõe "êmico", ou seja, a interpretação do cientista será sempre na visão e na perspectiva dos entrevistados, não na do pesquisador ou ainda a partir dos dados da literatura. Seria um método (p. 510):

voltado especificamente para os settings das vivências em saúde. Aquele que busca interpretar os significados - de natureza psicológica e complementarmente sociocultural trazidos por indivíduos (pacientes ou outras pessoas preocupadas ou que se ocupam com problemas da saúde, tais como familiares, profissionais de saúde e sujeitos da 
comunidade) acerca dos múltiplos fenômenos pertinentes ao campo dos problemas da saúde-doença.

O método clínico-qualitativo tem a peculiaridade de levar o pesquisador a utilizar um quadro bastante eclético no que diz respeito a referenciais teóricos tanto na redação de seu projeto como na discussão dos resultados, o que, em nosso modo de ver, coloca esse método na categoria da interdisciplinaridade, proposta base da Psico-Oncologia.

Segundo Turato (2005), existem três pilares que são demarcadores e que caracterizam o método clínico qualitativo. $\mathrm{Na}$ verdade são três atitudes que devem ser desenvolvidas pelo pesquisador: a atitude existencialista, a atitude clínica e a atitude psicanalítica. Nas palavras do autor (p.510):

uma postura de acolhida das angústias e ansiedades inerentes ao ser humano, uma aproximação própria de quem habitualmente trabalha na ajuda terapêtica, e a escuta e a valorização dos aspectos psicodinâmicos mobilizados sobretudo na relação afetiva e direta com os sujeitos sob estudo.

No método qualitativo, o interesse do pesquisador vai buscar o significado dos fenômenos, pois estes têm uma função organizadora nos seres humanos, e, ainda os significados que as coisas passam a ter, são compartilhados com outras pessoas culturalmente, gerando a organização de um grupo social que tem como centro essas representações e simbolismos.

Além da importância do significado, o método qualitativo tem ainda a característica de trabalhar com o sujeito em seu ambiente natural. O campo onde ocorrerá a observação é o locus vivendi do sujeito, sem controle de variáveis como ocorre nas situações experimentais tradicionais.

Ainda segundo Turato (2005), outra propriedade desse método de investigação é que o pesquisador é o próprio instrumento de pesquisa, 
ele usa seus órgãos dos sentidos para apreender aquilo que estuda, de forma que esses dados passem à sua consciência, onde tornam-se fenomenologicamente representados a fim de poderem ser interpretados.

Uma quarta característica desse método é a força no rigor da validade dos dados, isso por conta de que a observação dos sujeitos é acurada, bem como sua escuta nas entrevistas, estas em profundidade tal que aproximam o pesquisador da essência do problema.

A quinta e última característica diz respeito à questão da generalização, que não é feita a partir dos resultados obtidos, pois não se funda em quantificações ou relações causais. Tudo fica submetido aos pressupostos iniciais revistos, aos conceitos construídos, e ao conhecimento original produzido. Caberá aos leitores da pesquisa utilizá-los para o exame de sua plausibilidade e eventualmente replicálos em outras situações de pesquisa.

Por essas definições e caracterizações do método qualitativo de maneira geral e do método clínico qualitativo em particular, podemos ver como é um método que é adequado para pesquisas na PsicoOncologia uma vez que vem ao encontro daquilo que consideramos importante investigar nessa área.

A essência dos problemas que atingem os pacientes, seus familiares e mesmo as equipes de saúde ligadas ao câncer pode muitas vezes se perder com a utilização de metodologia quantitativa.

Questões de caráter muito íntimo, tais como relacionamentos, sentimentos, sexualidade, em geral vêm acompanhadas de angústia e ansiedades naturais nesses casos, uma vez que se está falando de doença, dor, morte, medo.

Quanto mais desarmado se encontrar o pesquisador, mais poderá entrar em contato com aquilo que está sendo exposto pelo entrevistado, extraindo dessa experiência possibilidades de revisão de sua própria visão de mundo. 
Ora, isso implica uma ruptura epistemológica muitas vezes difícil de ser aceita não só pela academia, mas pelo próprio investigador, moldado na tradição positivista da neutralidade e impessoalidade em relação ao seu objeto de estudo.

É fundamental que aquele que opta por um trabalho de caráter qualitativo não o faça por dificuldades de outra ordem, tais como o manejo da matemática e da estatística, muito menos por critérios de exclusão em geral polêmicos, mas sim por uma escolha que carrega em si, como "o fascínio em querer entender o querer-dizer dos fenômenos humanos" (Turato, 2003).

Campos, Alvarez e Bach (2003), em pesquisa realizada com pacientes em fila de espera para a realização de transplante de medula óssea, além de entrevista semidirigida, utilizou pranchas do Teste de Apercepção Temática (TAT), "a fim de possibilitar uma investigação mais profunda dos movimentos psicodinâmicos dos pacientes, no momento da opção pelo Transplante de medula Óssea" (p. 27)

Nesse estudo, a opção pela pesquisa qualitativa e pelo estudo de caso possibilitou a observação das reações de cada indivíduo face ao diagnóstico de câncer, e da indicação para o TMO (Transplante de Medula Óssea).

O dado mais importante descoberto pelas autoras desse estudo foi a total ignorância por parte dos pacientes em relação ao procedimento ao qual iriam ser submetidos (TMO), independentemente da faixa etária, classe social e escolaridade.

Esse dado serviu de subsídio para a orientação pré-transplante necessária nesses casos, o que era um dos objetivos do trabalho.

Goode e Hatt (1968) afirmam que esse tipo de abordagem é ideal quando o objetivo é estudar algo singular, e Gimenes (1998) lembra que nas pesquisas que adotam métodos quantitativos não se obtém muita informação sobre a construção da experiência do adoecer nos sujeitos, como mobilizaram forças para o enfrentamento e para recuperar a saúde. 
Pacientes e familiares em situações estressantes como doenças, intervenções cirúrgicas, internações, muitas vezes apresentam quadros "sub-clínicos" do ponto de vista psicopatológico, que devem ser cuidados precocemente antes que se transformem em comportamentos que poderão influenciar no desenvolvimento do processo. É importante, portanto, estar atento a essas manifestações, não só para poder intervir, mas para definir métodos eficazes de intervenção.

Segundo Campos, Alvarez, Machado e Rodrigues (2007), o atendimento à saúde de forma integral implica sempre um repensar de teorias e práticas. Em publicação decorrente de intervenção com mães que haviam se afastado aparentemente de seus filhos e de suas tarefas em relação aos mesmos, em função da angústia experimentada pela possibilidade de morte dos filhos como consequência do câncer os autores foram obrigados a redesenhar o projeto inicial em função das ocorrências ao longo da realização do mesmo.

Esse trabalho foi feito a partir da solicitação de uma casa de apoio a crianças portadoras de câncer, em tratamento ao longo do processo de realização de um Transplante de Medula Óssea.

Foi proposta a realização de um grupo com as mães, para que tivessem espaço para discutir a doença de seus filhos, suas angústias, medos e desamparo. Após o primeiro encontro, em que as mães pouco falaram, o grupo não conseguiu se reunir pela ausência da maioria das mães.

A equipe coordenadora optou por mudar a ideia inicial a ser desenvolvida nos encontros, e iniciou um processo lúdico, em que as mães podiam brincar, utilizando suas recordações de infância e seus jogos prediletos. Não se falaria de doença.

A partir dessa proposta, abandonou-se o projeto inicial onde ocorreriam dramatizações sobre a problemática trazida pelas participantes.

Após alguns encontros, relaxadas pelas atividades lúdicas, as mães puderam trazer o material recalcado relativo à enfermidade dos 
filhos, permitindo uma elaboração mais profunda dos problemas, o que resultou em sua volta às atividades e responsabilidades com a casa e com os filhos.

A intervenção em grupo, relatada no trabalho, mostra que a metodologia qualitativa com sua flexibilidade pode ser uma forma eficaz de produzir um conhecimento mais amplo e de caráter compreensivo, em que o processo de pesquisa ocorre paralelamente a algumas intervenções que modificam o entendimento que os participantes têm do problema discutido.

Concluindo, a produção de conhecimento em Psico-Oncologia pode ser um campo fascinante, pois em sua amplitude inclui a Oncologia, a Psiquiatria, a Psicologia da Saúde e as Ciências Sociais, que pesquisam a forma de entender e reagir a um câncer bem como a adaptação à doença em suas diferentes fases e em diferentes culturas.

Segundo Cella, Jacobsen e Lesko (1990), até 1970, as publicações decorrentes de pesquisas em Psico-Oncologia eram ausentes, lutando com dificuldades para a obtenção de fundos para a sua realização, hoje os estudos sobre adaptação ao câncer, controle da dor, qualidade de vida, aspectos espirituais, hereditariedade, entre outros, invadem as publicações científicas mostrando na prática o caráter interdisciplinar da Psico-Oncologia. Hoje, ao contrario de um passado recente, a pesquisa nestas áreas conta com apoio dos órgãos de fomento em todos os lugares do mundo.

Nossa intenção com essa reflexão sobre a produção de conhecimento na Psico-Oncologia foi propor a metodologia clínicoqualitativa como uma das contribuições para as pesquisas em PsicoOncologia. Nas palavras de Turato (2003, p. 86) autor deste método:

Tanto quanto qualquer disciplina, a psicologia do campo da saúde deve manifestar anseio pela interdisciplinaridade. [...] Qualquer que seja o pesquisador que aprofunde seus estudos e direcione sua práxis (ação), de modo interdisciplinar, estará contribuindo com esta relevante etapa histórica do desenvolvimento do conhecimento científico geral e de sua epistemologia. 
Sabemos da importância dos dados obtidos através de escalas e questionários que nos fornecem informações importantes sobre aspectos emocionais do adoecer por câncer, a adaptação a doença, o seu enfrentamento.

Além desses, outros dados são fundamentais nas questões relacionadas à epidemiologia e rastreamento de uma doença que insiste em atingir mais vítimas a cada dia.

Qual será a causa do crescimento do número de casos de câncer?

No Brasil, é a segunda causa de morte, e chega a matar 130 mil pessoas por ano. De acordo com o INCA, Instituto Nacional do Câncer, quase 500 mil novos casos surgem, principalmente sob a forma de câncer de próstata e pulmão nos homens, e mama e colo uterino nas mulheres.

Acreditamos que não podemos ter uma resposta para esse crescimento tão cedo, e a conduta aconselhada por pesquisadores dos principais centros de investigação ligados ao câncer é ensinar a aprender como conviver com a doença, uma vez que ainda não conseguimos controlá-la.

Se as pesquisas não podem nos levar à descoberta da cura para o câncer é importante continuarmos as investigações necessárias, para que possamos desenvolver ferramentas que ajudem os pacientes a utilizar um método eficaz para lidar com a doença. 


\section{REFLEXÕES FINAIS}

Iniciei este trabalho questionando "Por que se faz uma Livre Docência".

Ao terminar, as respostas parecem bem claras, tanto pela sensação de ter feito um trabalho que cumpriu com o objetivo de apresentar uma área de tal forma que quem se aproxime desta leitura possa entender um pouco o que é Psico-Oncologia, como ainda com o sentimento de que meu trabalho ao longo de minha carreira acadêmica ficou registrado para eventuais consultas dos interessados nesta área.

Além disso, apesar de escrever sobre um assunto que conheço bastante bem, muitas vezes a parada obrigatória para consulta à bibliografia foi gratificante, pois atualizou meus conhecimentos além de fazer-me refletir sobre os mesmos.

$\mathrm{Li}$, aprendi e repensei algumas ideias antigas, substituindo-as por novas.

Alguns segmentos da Psico-Oncologia que, por questões relacionadas a interesses pessoais, não haviam recebido um estudo aprofundado de minha parte foram revistos dando-me informações que, embora já as tivesse, não estavam tão claras em minha memória como agora.

O capítulo sobre câncer não quer mostrar um conhecimento médico, longe disso, mas, sim, reafirmar a importância de um conhecimento sobre a doença de modo geral, sem o qual não poderemos entender nossos pacientes e suas famílias de maneira eficiente.

No prefácio de seu segundo texto, Holland (1998) afirma que os autores do Handbook of Psycho-Oncology, escrito quase uma década antes, realmente aprenderam mais com o passar do tempo e com seus true experts, os pacientes e suas famílias. 
Temos todos muito que aprender. As pesquisas e consequentes avanços em relação à luta contra o câncer não param de acontecer, portanto, a cada dia novas formas de intervenção médica ocorrem, bem como novas descobertas na área farmacológica, gerando novos comportamentos dos pacientes como resposta.

Em análise dos dez anos de publicação do Psycho-Oncology: Journal of the Psychological, Social, and Behavioral Dimensions of Cancer, que surge em 1992 como órgão oficial da International Psycho Oncology Society realizada por Garcia-Conde, Ibañez e Durá (2008), os autores afirmam a supremacia dos E.U.A. quanto ao número de publicações, o que é compreensível uma vez que a Psico-Oncologia nasceu nesse país, e sendo o mesmo local onde reside sua criadora Jimmie Holland, que coordena vários grupos de pesquisadores.

Após mais de duas décadas de produção de conhecimento em Psico-Oncologia, esses autores demonstram que atualmente algumas áreas dominam o cenário na produção dos pesquisadores (Garcia-Conde Ibañez e Dura, 2008). Os trabalhos sobre Intervenções psicológicas vêm em primeiro lugar, seguidos por artigos que se propõem a descrever os Sintomas psicológicos, Qualidade de Vida, Adaptação, Enfrentamento, o Manejo da Dor e outros sintomas.

$\mathrm{Na}$ verdade, o profissional de Psico-Oncologia presta assistência ao paciente desde o seu diagnóstico até sua eventual morte, o que faz com que sua produção possa alcançar um amplo quadro de possibilidades, evidentemente dependendo de seu interesse.

O grupo dos trabalhos que publica artigos sobre intervenções médicas é de especial relevância na análise de Garcia-Conde, et al (2008), todos relacionados à cirurgia, quimioterapia e radioterapia.

Segundo os autores da revisão supra citada, algumas publicações falam dos outros tratamentos que estão disponíveis na luta contra a enfermidade como, por exemplo, o Transplante de Medula Óssea, os tratamentos genéticos, a Hormonoterapia, além dos tratamentos que combinam diferentes técnicas. 
Ainda segundo esses profissionais, a maior parte dos trabalhos publicados na revista é de caráter empírico, existindo poucos artigos que se proponham a apresentar e/ou a discutir modelos teóricos.

Os autores demonstram que nos anos de 1995 e 1998, alguns estudos sobre mensuração de qualidade de vida, utilidade do Inventário de Personalidade de Eysenck, bem como a construção e a utilidade de um questionário (MAC) para medir estratégias de enfrentamento surgem nas publicações, sem, no entanto, ter uma continuidade significativa.

Um aspecto importante a ser citado em relação a essa análise é a existência de vários pesquisadores denominados "transeuntes", isto é, autores que fazem uma pequena incursão na área, e depois a abandonam, não publicando mais.

A Psico-Oncologia ultrapassou os muros do Memorial Sloan Kettering Cancer Center de New York, vários encontros mundiais foram e continuam sendo realizados, congregando profissionais interessados na área.

Embora os diferentes tipos de câncer em sua natureza biológica e opções de tratamento sejam muito similares nas diferentes regiões onde surjam, existem profundas diferenças no que diz respeito à relação com a doença, e à atitude tanto de pacientes e familiares quanto de médicos.

Essas atitudes refletem, na verdade, as influências religiosas e culturais próprias de determinados lugares e ainda uma forma de ser muito autoritária por parte dos médicos em algumas dessas culturas, embora possa ser mais igualitária em outras.

Segundo Holland e Marchini (1988, p. 1167), "the International Society has, as part of its mission, cross-cultural research examining these cultural differences in cancer". 
Uma das dificuldades encontradas pelos psico-oncologistas na luta contra o câncer é o número de crenças que ainda cercam a doença e como ela ocorre.

Holland \& Lewis (2000) relatam que as pessoas estão sempre lendo sobre o que é o câncer, os amigos relatam fatos que ligam a ocorrência da doença a um problema que aconteceu pouco antes ao paciente como, por exemplo, um divórcio, e acabam cometendo muitos erros conceituais baseados em pesquisas inacabadas e incompletas, sem evidência científica.

Segundo a autora, um dos erros mais comuns em relação aos que sobrevivem a um câncer é cometido pelos que atribuem a remissão da doença aos "pensamentos positivos" que o paciente teria desenvolvido em relação a ela. Esquecem, diz a autora, que se submeteram a tratamentos médicos de primeira linha, que seguiram à risca as prescrições médicas e ainda que tiveram um diagnóstico precoce da doença, o que é um dado fundamental para a eventual remissão.

Holland (2002) relata vários casos de pacientes que fizeram tudo isso, treinaram todos os pensamentos positivos que puderam e infelizmente viram a doença progredir até que vieram a falecer. Embora possamos reconhecer uma conexão mente-corpo nos processos de câncer, essa relação está associada a estados emocionais que ocorrem em consequência da doença, de seu progresso e de seus tratamentos.

A autora demonstra que passou a respeitar esse tipo de atitude como se respeita uma crença religiosa. As pessoas que acreditam em alguma coisa baseadas apenas na crença não necessitam de nenhuma comprovação científica para continuarem acreditando. Holland e Lewis (2002) falam do imenso esforço e energia gastos inutilmente na tentativa de tentar mudar essas posturas das pessoas. Propõem que é obrigação da equipe de saúde respeitar cada crença pessoal sobre o câncer, sem deixar jamais os tratamentos médicos. Mas lembra que a pessoa que tem câncer necessita ser acolhida, independentemente de 
seu ponto de vista sobre a doença, sem ter medo da crítica ou do quão ridículas suas crenças pareçam.

$\mathrm{Na}$ verdade, sabemos que uma pessoa portadora de qualquer doença está em um estado de tal desamparo que necessita antes de tudo de acolhimento, respeito e suporte psicológico. No caso dos pacientes portadores de câncer esse estado é agravado pelo fato de o câncer ser realmente uma doença grave que pode levar à morte. Se a pessoa acredita que a realização de um ritual pode ajudá-la, devemos respeitar seu comportamento. $O$ respeito e o acolhimento criam um tipo de vínculo entre o paciente e o cuidador que é fundamental para o processo que irá se desenvolver ao longo da doença até sua remissão ou morte. Seja no caso da adesão aos tratamentos, ou mesmo de uma relativa tranquilidade face à aproximação da morte.

Holland (2002) se diz inteiramente confortável em seu lugar "a meio do caminho", ${ }^{4}$ como relata, de um lado não abre mão de sua crença segura nos valores da ciência, de outro lado, tudo que possa auxiliar o paciente e fazê-lo sentir-se bem deve ser aceito e incentivado pois acaba permitindo uma relação de confiança que só pode auxiliar a atuação do psico-oncologista.

A Psico-Oncologia tem ainda muitos desafios pela frente, que dependem de um entrosamento real entre os clínicos, os pesquisadores e principalmente das políticas de saúde de cada país para que possa criar condições cada vez melhores tanto de sobrevivência quanto de qualidade de vida nessa sobrevivência para os pacientes portadores de câncer.

Embora sem grandes fundos para a pesquisa, e muitos tratamentos sem cobertura por parte dos planos de saúde, existem muitos movimentos e campanhas espontâneas para auxiliar o desenvolvimento do conhecimento na luta contra o câncer.

4 No texto original "in the middle of the road". 
De acordo com Gruman e Convissor (1998, p. 1176),

"a growing number of researchers will be competing for a limited amount of funds. Only through creative, collaborative efforts will place psychosocial research at the top of the agenda".

Segundo esses autores, os pesquisadores e clínicos vêm trabalhando arduamente para incorporar seu conhecimento sobre fatores psicossociais e comportamentais relacionados ao câncer, a uma prática e a uma política voltadas para o cuidado com a saúde.

Sabemos quão difícil é para um paciente procurar uma ajuda especializada quando é acometido pela doença. É mais fácil um familiar tomar a iniciativa. No entanto, após os primeiros contatos, pacientes e familiares percebem os benefícios de um trabalho com um psicooncologista. Os depoimentos ao longo dos encontros e mesmo no final de um trabalho psicológico dessa natureza são sempre positivos, realçando como a ajuda recebida é de uma natureza específica e eficaz.

Infelizmente ainda não temos a visibilidade que gostaríamos em nosso trabalho e em nossos serviços. $E$, como dissemos, as crenças negativas sobre o câncer podem ser um impeditivo para a procura inicial. Reverter essa situação deve ser uma das missões de quem se propõe a trabalhar com Psico-Oncologia.

A partir do I Congresso Brasileiro de Psico-Oncologia em 1994, quando fiz a saudação à Profa. Dra. Maria Margarida de Carvalho, a profissional que foi uma das pioneiras na área trazendo-a para o Brasil, tenho sempre comparado profissionais que decidem dedicar-se a essa atividade a "Cavaleiros da Triste Figura". Cavaleiros, por serem lutadores e portadores de uma missão. Da Triste Figura, por trabalharem em uma área que pode trazer alegrias, mas muitas tristezas. 
Como o Cavaleiro Don Quixote, nos atiramos em um sonho em que transmitir esperança é fundamental, ainda que a mesma não exista mais objetivamente.

Mas, para o paciente, sonhar e desejar é fundamental, sempre.

Um desejo não é necessariamente realizado só porque existe um desejante. Mas no momento em que todos os hospitais e clínicas que atendem portadores de câncer criarem espaços formais para a atuação de psico-oncologistas, tanto a assistência quanto a produção de conhecimento deverão ser desenvolvidos com maior produtividade. A repercussão desses fatos beneficiará a todos e principalmente aos nossos pacientes.

Sabemos que isso ainda não é uma realidade, mas o sonho pode ser o primeiro passo para sua realização. 


\section{REFERÊNCIAS BIBLIOGRÁFICAS}

Ader, R. Cohen \& N. Felten, D. (1995) Psychoneuroimmunology:interactions between the nervous system and the immune system. The Lancet. 345. (pp 99-102)

Alexander, F. (1989). Medicina Psicossomática: seus princípios e aplicações. São Paulo: Martins Fontes.

Almanza-Muñoz \& Holland (2000) Psico-oncología: estado actual y perspectivas futuras. Cancerologia. 46(3) pp. 196-206

Angerami-Camon, V.A. (Org.). (2000) Psicologia da saúde: um novo significado para a prática clínica. São Paulo: Pioneira.

Anelli, A. \& Noronha, S. (2002). Marcadores Tumorais In L.P. Kowalski; A. Anelli; J.V. Salvajoli \& L.F. Lopes (Orgs.), Manual de condutas diagnósticas e terapêuticas em oncologia (pp. 60-63). São Paulo: Editora Âmbito.

Bianchi, A. (2002) A pediatria oncológica. In L.P. Kowalski; A. Anelli; J.V. Salvajoli \& L.F. Lopes (Orgs.), Manual de condutas diagnósticas e terapêuticas em oncologia (p. 209). São Paulo: Editora Âmbito.

Bronowski, J. (1979). Ciência e valores humanos. São Paulo: Editora da Universidade de São Paulo.

Buron, R.R.; Rodriguez, J.A.; Linares, V.R. \& Lopez, L.J.G. (2008) Psicologia y câncer. Suma Psicológica, 15(1), p.171-198

Caballero, M. M.; Bermejo, Fernández F.; Nieto, R. G. \& Caballero, M. F. (2001, mar). Prevalence And Factors Associated With Burnout in health area. Aten Primaria. 27(5), 313-7.

Caballero, O. L. \& Simpson, A.J.G. (2002). Projeto genoma humano e suas implicações para a saúde humana - visão geral e contribuição brasileira para o projeto. In L.P. Kowalski; A. Anelli; J.V. Salvajoli \& L.F. Lopes (Orgs.), Manual de condutas diagnósticas e terapêuticas em oncologia (pp. 49-51). São Paulo: Editora Âmbito.

Callanan, M. \& Kelley, P. (1994). Gestos Finais. São Paulo: Nobel.

Camon, V.A.A. (2000). Psicologia da Saúde. São Paulo: Pioneira.

Campos, E.M.P. (2000) Grupos de Auto-Ajuda. In V.L. Santos \& I.U. Cesaretti (Orgs.). Assistência em Estomaterapia (pp.291-325). São Paulo: Atheneu.

Campos, E.M.P. (1998). A História de um Serviço. In M.M. CARVALHO (Org.) Resgatando o Viver (pp.72-84). São Paulo: Summus. 
Campos, E.M.P.; Alvarez, M. \& Bach, C. (2003). Estados emocionais do paciente candidato a transplante de medula óssea. Teoria e Prática, 5(2), 23-36.

Campos, E.M.P.; Alvarez, M. \& Machado, P. (2004). Infância e Família. In J. Melo (Coord.) Doença e Família (205-216). São Paulo: Casa do Psicólogo.

Campos, E.M.P.; Rodrigues, A.L.; Machado, P. \& Alvarez, M. (2007). Intervenção com mães em casa de apoio. Psicologia em Estudo., 12(3), 635-640.

Campos, E.P. (2005). Quem cuida do cuidador. Petrópolis, R.J.: Vozes.

Carvalho, M.M.M.J. (Org.). (1994). Introdução à psiconcologia. Campinas: Editora Psy.

Carvalho, V.A.; Franco, M.H.P.; Kovács, M.J.; Liberato, R.P.; Macieira, R.C.; Veit, M.T., Gomes, M.J.B. et. al. (Orgs.). (2008). Temas em PsicoOncologia. São Paulo: Summus.

Castro, E.; Bornholdt, E. (2004). Psicologia da Saúde x psicologia hospitalar: definições e possibilidades de inserção profissional. Psicologia Ciência e Profissão, 24(3), pp. 48-57 Recuperado em 24 fev 2010, de http://pepsic.bvs-psi.org.br/scielo.php?script=sci arttext\&pid=S141498932004000300007\&lng =pt\&nrm =iso

Cella, D.F.; Jacobsen, P.B. \& Lesko, L.M. (1990). Research methods in Psychooncology. In J.C. Holland \& J.H. Rowland (Orgs.) Handbook of Psychooncology (737-749). New York: Oxford University Press.

Cervi, A.; Hermsdorf, H.H.M. \& Ribeiro, R.C.L. (2005). Tendência da mortalidade por doenças neoplásicas em 10 capitais brasileiras, de 1980 a 2000. Revista Brasileira de Epidemiologia., 8(4), pp.407-418

Chauí, M. (1999). Convite à Filosofia. (11 a ed.) São Paulo: Ática.

Coelho, F.R.G. (1998). O Controle do Câncer. In M.M. Brentani; F.R.G. Coelho; H. Iyeyasu \& L.P. Kowalski (Orgs) Bases da Oncologia (pp.1-22). São Paulo: LEMAR.

Coyne, J. C.; Benazon, N. R.; Gaba, C.G.; Calzone, K.; Weber, B. L. (2000). Distress and Psychiatric Morbidity Among Women From High-Risk Breast and Ovarian Cancer Families. Journal of Consulting and Clinical Psychology, 68(5), 864-874.

Die Trill, M. (1998). Influencia de la Cultura em la Experiência del câncer. Psiconcologia 0(1), 39-4.

Eco, U. (1997). Come si fa uma tesi di láurea: le materie umanistiche. Milano: Editora 7.

Eliade, M. (1969). Origens: história e sentido na religião. Lisboa: Edições 70. 
Engel, G. (1977, April 8). The need for a new medical model: A challenge for biomedicine. Science, 196, 129-136.

Foucault, M. (1963). O Nascimento da Clínica. (1a ed. brasileira). Rio de Janeiro: Forense-Universitária.

Freud, S.(1986) El Porvenir de una Ilusion. In. Freud S, Obras Completas V. $X X I$ (pp.1-56). Buenos Aires: Amorrortu Editores

Freud S (1986) Psicologia de lãs masas y análisis del yo in Freud ,S. Obras Completas V.XVIII (pp 63-126)

Garcia-Conde, A.; Ibañez E. \& Durá E. (2008, Marzo). Analisis del contenido de la revista Psycho-Oncology. El desarrollo de la investigación em psicooncologia. Boletin de Psicologia, (92), 81-113

Gimenes, M.G.G. (1994). O que é Psiconcologia. In M.M. Carvalho (Org.). Introdução à Psiconcologia (pp.35-56). Campinas: Editorial Psy II.

Gimenes, M.G.G. (1998). A pesquisa do enfrentamento na prática psicooncológica. In M.M. Carvalho (Org.). Psico-Oncologia no Brasil resgatando o viver (pp. 232-246). São Paulo: Summus.

Goode, W.J. \& Hatt, P.K. (1968). Métodos em pesquisa social. São Paulo: Companhia Editora Nacional.

Grassi, L.; Biancosino, B.; Marmai, L.; Rossi, E. \& Sabato, S. (2007). Psychological Factors Affecting Oncology Conditions. In P. Porcelli \& N. Sonino (Orgs.) Psychological Factors Affecting Medical Conditions (pp.5771) Basel: Karger.

Gruman J. \& Convissor ,R. (1998) Bridging the Gap Between Research, Clinical Practice and Policy in Holland, J. Psycho-Oncology ( $p$ 1176) NewYork, Oxford University Press.

Guba, E. C. (1990). The Alternative Paradigm Dialog. In The paradigm Dialog. Califotrnia, Sage Publications.

Holland, J.C. (1998). Psycho-Oncology. New York: Oxford University Press.'

Holland, J.C. (2002). History of psycho-Oncology: Overcoming attitudinal and conceptual barriers. Psychosomatic Medicine, 64, 206-221. New York: Oxford University Press

Holland, J.C. \& Lewis, S.(2000) The Human side of cancer. New York: Harper Collins Publishers

Holland J. \& Marchini A. (1998)International Psycho-Oncology in Holland. J. Pscho-Oncology ( p. 1167 ) NewYork, Oxford University Press.

Holland, J.C. \& Rowland, J.H. (1990). Handbook of Psychooncology: Psychological Care of the patient with cancer. New York: Oxford University Press. 
Klein, M. (1991). Sobre o desenvolvimento do funcionamento mental. In Klein, M. Inveja e Gratidão e outros trabalhos (pp.270-279). Trad.da 4a. ed. inglesa Elias Mallet da Rocha, Liana Pinto Chaves (coord). e col.Rio de Janeiro: Imago Editora.

Kovács, M.J. (2002). Educação para a morte: um desafio na formação de profissionais de saúde e educação. Tese de livre-docência, Instituto de Psicologia, Universidade de São Paulo, São Paulo.

Kovács, M.J.; Macieira, R.C. \& Carvalho, V.A. (2008). Formação profissional em Psico-Oncologia. In Carvalho, V.A.; Franco, M.H.P.; Kovács, M.J.; Liberato, R.P.; Macieira, R.C.; Veit, M.T., Gomes, M.J.B. et. al. (Orgs.).Temas em Psico-Oncologia (pp.543-555). São Paulo: Summus.

Koyre, A. (1991). Estudos de História do Pensamento Científico. (2a ed.) Brasília: Editora Forense Universitária.

Kowalski, L.P. (1998). Diagnóstico, Estadiamento e Princípios do Tratamento do Câncer. In M.M. Brentani; F.R.G. Coelho; H. Iyeyasu \& L.P. Kowalski (Orgs.), Bases da Oncologia. (pp. 173-202) São Paulo: LEMAR.

Kowalski, L.P.; Magrin, J. \& Carvalho, A.L. (2002). Diagnóstico e Estadiamento dos Tumores. In L.P. Kowalski; A. Anelli; J.V. Salvajoli \& L.F. Lopes (Orgs.), Manual de condutas diagnósticas e terapêuticas em oncologia (pp.35-40). São Paulo: Âmbito Editores.

Kubler-Ross, E. (1981). Sobre a morte e o morrer. São Paulo: Martins Fontes.

Le Shan, L. (1994). Brigando pela Vida. São Paulo: Summus.

Lipowski. Z.J. (1984, March/April). What Does the Word "Psychosomatic" Really Mean? A Historical and Semantic Inquiry. Psychosomatic Medicine, 46(2), 153.

Mello Filho, J. \& Burd, M. (2010. Psicossomática Hoje. 2a. ed. Porto Alegre: ARTMED

Morin, E. (1997) O Homem e a Morte. Rio de Janeiro. Imago

Nobre de Melo, A.L. (1970). Psiquiatria: Psicologia Geral e Psicopatologia. São Paulo: Atheneu.

Ogden, J. (2004). Psicologia da saúde. (C. Patrocínio \& F. Andersen, trads). ( $2^{\mathrm{a}}$ ed. rev.). Lisboa: Climepsi.

Okamura, H. (1998). Cancer Genetic Counselling and Psycho-Oncology. Japanese Journal of Clinical Oncology. 28, pp.461-462.

Pedrosa, M.A.L. (2010). Reflexões sobre Michael Ballin: comunicando uma experiência de grupos. In J. Mello Filho \& M. Burd (Orgs.), Psicossomática Hoje. ( $2^{a}$ ed.). Porto Alegre: ARTMED. 
Perina, E.M.; Mastellaro, M.J. \& Nucci, N.A.G. (2008). Efeitos tardios do tratamento do câncer na infância e na adolescência. In Carvalho, V.A.; Franco, M.H.P.; Kovács, M.J.; Liberato, R.P.; Macieira, R.C.; Veit, M.T., Gomes, M.J.B. et. al. (Orgs.). Temas em Psico-Oncologia. São Paulo: Summus.

Pessini, L.; Bertachini, L. (Orgs.). (2006). Humanização e Cuidados Paliativos. São Paulo: EDUNISC.

Pimenta, C.A.M. \& Koziume, M.S. (1993, ago). Analgesia em câncer, crenças e atualização. Escola de Enfermagem USP, 27(2), 309-313.

Porcelli, P. \& Sonino, N. (2007). Pyschological Factors Affecting Medical Conditions. Switzerland: Basel.

Ramirez, A.J.; Graham, J.; Richards, M.A.; Cull, A.; Gregory, W.M. et al. (1995, June). Burnout And Psychiatric Disorder Among Cancer Clinicians. Br J Cancer, 71(6), 1263-1269.

Ribeiro, E.M.P.C. (1991). O Exercício do papel de Psico-Terapeuta por psicólogos: alguns fatores presentes a escolha. Tese de Doutorado. Instituto de Psicologia. Universidade de São Paulo. São Paulo.

Ribeiro, E.M.P. (1994). O paciente terminal e a família. In M.M.M.J. Carvalho (Org.) Introdução a Psiconcologia (pp. 199-218). Campinas: Editora Psy.

Ribeiro, E.M.P. (1998). A História de um Serviço. In M.M.J. Carvalho (Org.). Resgatando o Viver (pp.72-84). São Paulo: Summus.

Richmond, C. (2005, 23 julho). Dame Cicely Saunders [Editorial] British Medicine Journal, 331(7509)

Rothman, A. \& Suls, J. (2004). Evolution of the Biopsychosocial Model: Prospects and Challenges for Health Psychology. Health Psychology, 23(2), 119-125

Rosen, S. (1994) Minha voz irá contigo. Os contos didáticos de Milton Erickson. Campinas: Editorial Psy

Ruffié, J. (2002). Biologia Humana e Medicina de Predição. In E. Morin $A$ religação dos saberes (pp.248-250). Rio de Janeiro: Bertrand Brasil.

Schavelzon J. (2004) Psiconcologia - Princípios Teóricos y Práxis para el siglo XXI Buenos Aires : Letra Viva

Schmitt, F.C.L. (1991). Aspectos básicos em patologia tumoral. In G. Schwartsmann, Katz, A., Cunha, F.M., Vinholes, J., Gansl, R.C. Simon, S.D. et. al.(Org.). Oncologia clínica, clínica e práticas (pp.42-53). Porto Alegre: Artes Médicas. 
Sebastiani, R.W. (2000). Psicologia da Saúde no Brasil: 50 anos de história. Recuperado em 20 de janeiro de 2010 de http://www.nemeton.com.br/nemeton/artigos/Psicologia-daSa\%C3\%BAde-no-Brasil.doc

Segre, M. \& Cohen, C. (Orgs.) (1995). Bioética. São Paulo: Edusp.

Servan-Schreiber, D. (2008). Anticâncer. Rio de Janeiro: Objetiva.

Simonton, O.C.; Simonton, S.M. \& Creighton, J. (1987). Com a Vida de Novo: uma abordagem de auto-ajuda para pacientes com câncer. São Paulo: Summus Editorial.

Spink, M. (1992). Psicologia da Saúde: a estruturação de um novo campo de saber. In F.C.B. Campos (Org.). Psicologia e Saúde (pp.11-23). São Paulo: HUCITEC.

Spink, M. (2003). Psicologia Social e Saúde. São Paulo: Editora Vozes.

Steinherz, P.G.; Simone, J. (1998). Biology of childhoold cancers. In J.C. Holland (Org.). Psycho-Oncology (pp.881-896). New York: Oxford University Press.

Stainbrook, E. (1952). Psychosomatic Medicine in the Nineteenth Century. Psychosomatic Medicine, XIV (3), pp. 211-272

Tucunduva, L.T.C.M.; Garcia, A.P.; Prudente, F.V.B.; Centofanti; G.; Souza, C. M. et al. (2006, Mar/Apr).Incidence Of The Burnout Syndrome Among Brazilian Cancer Physicians. Revista da Associação Médica Brasileira, 52 (2), p.108-112

Turato, R. E. (2000) Introdução à metodologia da pesquisa clínico-qualitativa - definição e principais características. Revista Portuguesa de Psicossomática, 2(1), pp.93-108

Turato, R.E. (2003). Tratado da metodologia da pesquisa clínico-qualitativa. Petrópolis: Editora Vozes.

Turato, E.R. (2005). Métodos qualitativos e quantitativos na área da saúde: definições, diferenças e seus objetos de pesquisa. Revista de Saúde Pública, 39(3), 507-14.

Yamaguchi, N. (1994). O câncer na visão da Oncologia. In M.M. Carvalho (Org.). Introdução à Psico-Oncologia (pp.21-32). Campinas: Editorial Psi. 


\section{BIBLIOGRAFIA DE APOIO}

Afonso, M. L. (org.) (2006) Oficinas em dinâmica de grupo: um método de intervenção psicossocial. São Paulo: Casa do Psicólogo

Aresca, L., Birgin, D. E Blum, S. Psicooncologia: diferentes miradas. $1^{a}$ edição Buenos Aires: lugar, 2004.

Brandão, J. S. A (1998) Mitologia Grega. $8^{a}$ ed. Petrópolis: Editora vozes

Do Valle, E. R. M. (1997) Câncer infantil: compreender e agir. Campinas: Psy Editora.

Earp, A. C. de Sá. (1999) A angústia frente à morte: um estudo psicanalítico. Rio de Janeiro: SPID.

Freud, S. (1986) Obras completas. Trad. José Luis Etchecerry. Buenos Aires: Amorroutu editores

Foucault, M. (1977) O nascimento da Clínica. Trad. Roberto Machado. $1^{a}$ Ed. Brasileira. Rio Janeiro: Forense-Universitária.

Guex, P. (1989) Introduction to Psycho-Oncology. New York: Routeledge.

Ismael, S.M.C. (org.). (2005) A prática psicológica e sua interface com as doenças. São Paulo: Casa do Psicólogo.

Ismael, S.M.C. (org.) (2005) Temas de prevenção, ensino e pesquisa que permeiam o contexto hospitalar. São Paulo: Casa do Psicólogo

Kübler-Ross, E. (1969) Morte: estágio final da evolução. Trad. Paulo Menezes. São Paulo: Martins-Fontes Ed.

Kuhn, T.S. (1962) A estrutura das revoluções científicas. 3a edição São Paulo: Editora Perspectiva.

Morin, E. (1999) O método. Porto Alegre: Sulina.

Parnia, S. (2008) O que acontece quando morremos. Trad. Emanuel Mendes Rodrigues. São Paulo: Larousse do Brasil.

Raimbault, G. (1979) A crianças e a morte: crianças doentes falam da morte, problemas da clínica do luto. Trad. Roberto Côrtes Lacerda. Rio de Janeiro: F. Alves Editora.

Kamón Y Cajal, S. (1979) Regras e Conselhos sobre a investigação Científica. São Paulo: Ed. da USP.

Schavelzon, J. (2004) Psiconcologia: princípios teóricos y práxis para El siglo XXI. Buenos Aires: letra Viva. 
Spillius, E. B. (editora) (1990) Melanie Klein Hoje: desenvolvimento da teoria e técnica. Trad. Belinda Piltchen Haber. Rio de Janeiro: Imago Ed.

Stedeford, A. (1986) Encarando a morte: uma abordagem ao relacionamento com o paciente terminal. Trad. Silvia Ribeiro. Porto Alegre: Artes Médicas.

Torres, W. C. (1999) A criança diante da morte: desafios. São Paulo; Casa do Psicólogo. 